Keywords: Sludge Batch 2, Rheology, Tank Farm, DWPF, SRAT, and SME

Retention: Permanent

\title{
Rheological and Physical Data Results for Tank 40 Radioactive Samples Compared to Nonradioactive Tank 40 Samples (U)
}

\author{
Authors: T.L. Fellinger \\ D.C. Koopman
}

Publication Date: October 18, 2002

Westinghouse Savannah River Company

Savannah River Site

Aiken, SC 29808

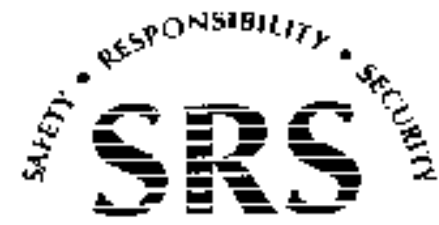

PREPARED FOR THE U.S. DEPARTMENT OF ENERGY UNDER CONTRACT NO. DE-AC09-96SR18500 
This document was prepared in conjunction with work accomplished under Contract No. DE-AC09-96SR18500 with the U. S. Department of Energy.

\section{DISCLAIMER}

This report was prepared as an account of work sponsored by an agency of the United States Government. Neither the United States Government nor any agency thereof, nor any of their employees, makes any warranty, express or implied, or assumes any legal liability or responsibility for the accuracy, completeness, or usefulness of any information, apparatus, product or process disclosed, or represents that its use would not infringe privately owned rights. Reference herein to any specific commercial product, process or service by trade name, trademark, manufacturer, or otherwise does not necessarily constitute or imply its endorsement, recommendation, or favoring by the United States Government or any agency thereof. The views and opinions of authors expressed herein do not necessarily state or reflect those of the United States Government or any agency thereof.

This report has been reproduced directly from the best available copy.

Available for sale to the public, in paper, from: U.S. Department of Commerce, National Technical Information Service, 5285 Port Royal Road, Springfield, VA 22161, phone: (800) 553-6847, fax: (703) 605-6900

email: orders@ntis.fedworld.gov

online ordering: http://www.ntis.gov/help/index.asp

Available electronically at http://www.osti.gov/bridge

Available for a processing fee to U.S. Department of Energy and its contractors, in paper, from: U.S. Department of Energy, Office of Scientific and Technical Information, P.O. Box 62, Oak Ridge, TN 37831-0062,

phone: (865)576-8401,

fax: (865)576-5728

email: $\underline{\text { reports@ adonis.osti.gov }}$ 


\section{Table of Contents}

1.0 INTRODUCTION AND SUMMARY.

2.0 BACKGROUND INFORMATION FOR THE SLUDGE BATCH 2 SAMPLES AND A BRIEF DESCRIPTION OF TASK ACTIVITIES

3.0 ANALYSIS PERFORMED ON THE SLUDGE SLURRY SAMPLES

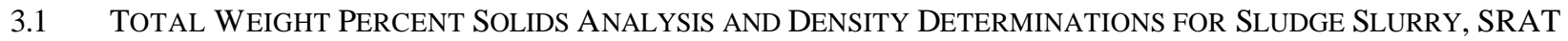
PRODUCT, AND SME PRODUCT FOR SLUDGE BATCH $2 .$.

3.2 WEIGHT PERCENT DISSOLVED SOLIDS ANALYSIS AND DENSITY DETERMINATIONS FOR SLUDGE SLURRY, SRAT

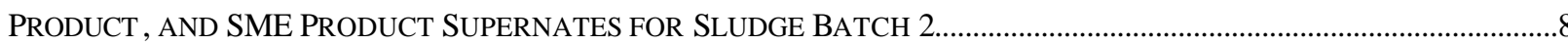

3.3 CALCULATION OF INSOLUBLE SOLIDS AND SOLUBLE SOLIDS FOR THE SLURRY SAMPLE, SRAT PRODUCT, AND

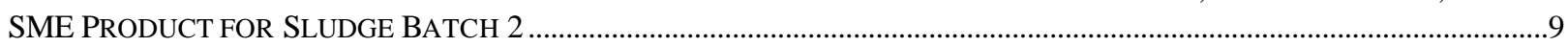

3.4 PH MEASUREMENTS FOR THE SLUDGE SLURRY, SRAT PRODUCT, AND SME PRODUCT FOR SLUDGE BATCH 2 .......10

4.0 RADIOACTIVE RHEOLOGICAL MEASUREMENTS OF SLUDGE SLURRY, SRAT PRODUCT, AND SME PRODUCT SAMPLES FOR SLUDGE BATCH 2 ...........................................................................................................................................10

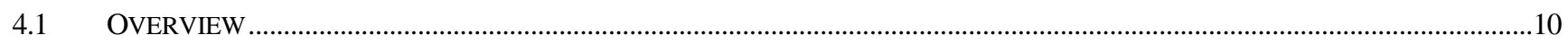

4.2 SUMMARY OF THE INSTRUMENT'S SPECIFICATIONS USED TO COMPLETE THE RHEOLOGICAL MEASUREMENTS..11

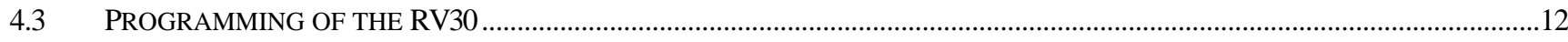

4.4 PREPARATION OF THE SLUDGE SLURRY, SRAT PRODUCT, AND SME PRODUCT SAMPLES FOR MEASUREMENT AND THE RESULTS OF THE UNCORRECTED FLOW CURVES...........................................................................................12

5.0 COMPARISON OF THE RADIOACTIVE SLUDGE BATCH 2 SAMPLES TO THE NONRADIOACTIVE SLUDGE

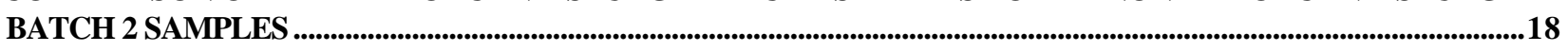

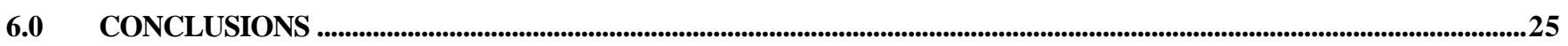

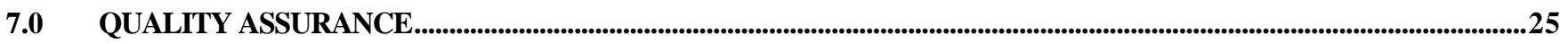

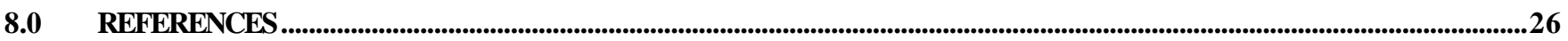

APPENDIX A -STANDARD OIL RESULTS (UP FLOW CURVES ONLY) .................................................................................................27

APPENDIX B - RAW DATA FOR THE RADIOACTIVE SLUDE BATCH 2 SAMPLES (UP FLOW CURVES ................ONLY) 36

APPENDIX C - DESCRIPTION OF THE INSTRUMENT USED TO PERFORM THE GFPS NONRADIAOCTIVE RHEOLOGY MEASUREMENTS AND FLOW CURVES OBTAINED FOR THE SLUDGE SLURRY AND SRAT PRODUCT.

APPENDIX D - RAW DATA FOR THE GFPS SLUDE SLURRY SAMPLES AND SRAT PRODUCT SAMPLES (UP FLOW

CURVES ONLY) .........................................................................................................................................................................................................61 


\section{List of Tables}

TABle 1 - TOtAl Weight PERCENT SOlidS ANALYSIS AND DENSITY DETERMinATIONS FOR THE SLUDGE SLURRY, SRAT

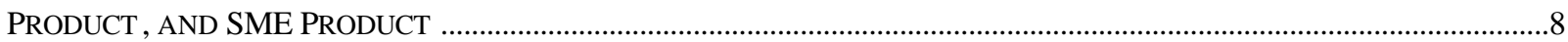

TABLE 2 - WEIGHT PERCENT DISSOLVED SOLIDS ANALYSIS AND DENSITY DETERMINATIONS FOR THE SLUDGE SLURRY,

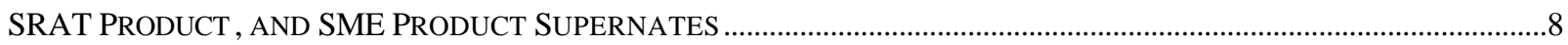

TABLE 3 - CALCULATED VALUES FOR THE INSOLUBLE AND SOLUBLE SOLIDS FOR THE SLUDGE SLURRY, SRAT PRODUCT,

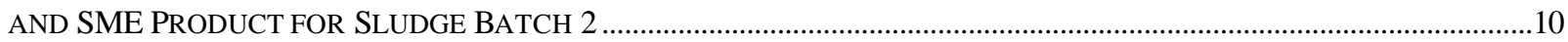

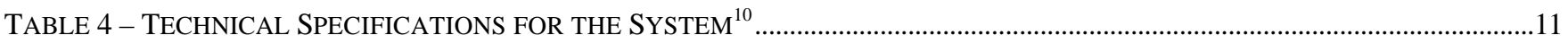

TABle 5 - MAXIMUM SHEAR RATE, MAXIMUM SHEAR StRESS, AND PHYSICAL DiMENSIONS ASSOCIATED WITH THE MVI ROTOR $^{10}$

TABLE 6 - PROGRAMMING TIMES AND SHEAR RATE RANGES SELECTED FOR THE SLUdGE SLURRY, SRAT PRODUCt, SME

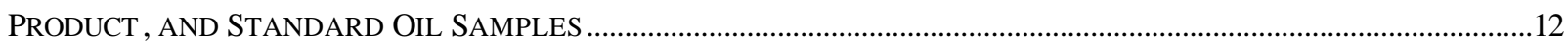

TABLE 7 - BINGHAM PLASTIC MODEL RESULTS FOR FIGURE 2, FIGURE 3, AND FIGURE 4...........................................................17

TABLE 8 - SUMMARY OF THE RESULTS OBTAINED FROM THE NONRADIOACTIVE AND RADIOACTIVE SLUDGE SLURRY SAMPLES FOR SLUDGE BATCH 2 COMPARED TO THE DWPF OPERATING REGION........................................................18

TABLE 9 - SUMMARY OF THE RESULTS OBTAINED FROM THE NONRADIOACTIVE AND RADIOACTIVE SRAT PRODUCT

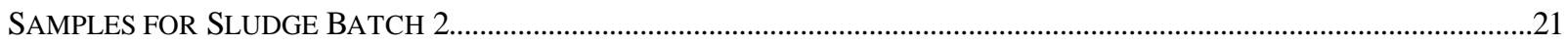

TABLE 10 - SUMMARY OF THE RESULTS OBTAINED FROM THE NONRADIOACTIVE AND RADIOACTIVE SME PRODUCT

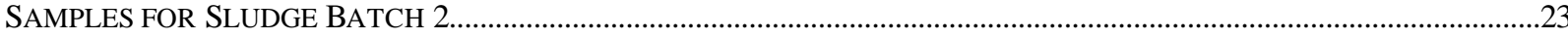




\section{List of Figures}

FigURE 1 - PICTURES OF THE SLUdGE SLURRY, SRAT PRODUCT, AND SME PRODUCT IN THE MEASURING CUP ....................13

FIGURE 2 - UNCORRECTED FLOW CURVE FOR THE SLUDGE BATCH 2 SLUDGE SLURRY SAMPLE...............................................13

FIGURE 3 - UNCORRECTED FLOW CURVE FOR THE SLUDGE BATCH 2 SRAT PRODUCT SAMPLE .................................................14

FIGURE 4 - UNCORRECTED FLOW CURVE FOR SLUDGE BATCH 2 SME PRODUCT SAMPLE …………………..............................16

FIGURE 5 - COMPARISON OF THE UNCORRECTED FLOW CURVES FOR SLUDGE SLURRY, SRAT PRODUCT, AND SME PRODUCT SAMPLES.

FiguRE 6 - YIELD STRESS (DyNES/CM²) DEPENDENCE ON INSOLUble WEIGHT PERCENT SOlidS FOR THE SLUDGE SLURRY

FiguRE 7 - CONSISTENCY (CENTIPOISE) RELATIONSHIP TO INSOLUBLE WEIGHT PERCENT SOLIDS FOR THE SLUDGE SLURRY

FIGURE 8 - YIELD STRESS (DYNES/CM²) DEPENDENCE ON INSOLUBLE WEIGHT PERCENT SOLIDS FOR THE SME PRODUCT

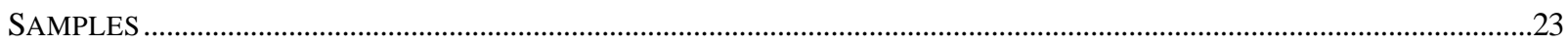

FIGURE 9 - CONSISTENCY (CENTIPOISE) RELATIONSHIP TO INSOLUBLE WEIGHT PERCENT SOLIDS FOR THE SME PRODUCT SAMPLES.

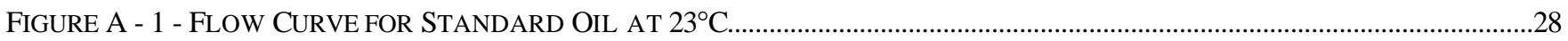

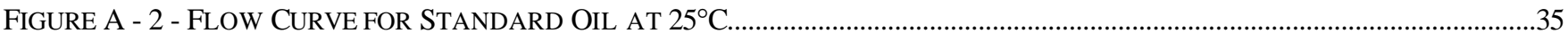

FIGURE C - 1 - UNCORRECTED FLOW CURVES FOR THE SLUDGE SLURRY SAMPLES FROM THE GFPS ........................................56

FIGURE C - 2 - COMPARISON OF THE UNCORRECTED FLOW CURVES FOR THE GFPS SLUDGE SLURRY SAMPLES TO THE

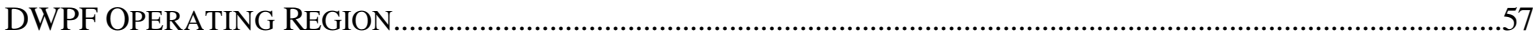

FIGURE C - 3 - UNCORRECTED FLOW CURVES FOR THE SRAT PRODUCT SAMPLES FROM THE GFPS ..........................................58

FIGURE C - 4 - COMPARISON OF THE UNCORRECTED FLOW CURVES FOR THE GFPS SRAT SAMPLES TO THE DWPF OPERATING REGION...

FiguRE C - 5 - COMPARISON OF THE UNCORRECTED FLOW CURVES FOR THE NONRADIOACTIVE SME SAMPLES TO THE DWPF OPERATING REGION. 


\subsection{INTRODUCTION AND SUMMARY}

The high level liquid waste generated at Savannah River Site (SRS), during many years of producing nuclear materials for the USA, is stored in underground steel tanks as caustic slurries. These slurries are either a sludge of hydrous oxides or a nitrate/nitrite salt slurry. The Defense Waste Processing Facility (DWPF) is currently receiving and processing the radioactive sludge slurry into a durable borosilicate glass for permanent geological disposal.

The DWPF can receive radioactive sludge slurry from one of two 1.3 million gallon High Level Waste (HLW) feed tanks. These feed tanks are called Tank 51 and Tank 40. Currently DWPF is receiving sludge slurry from Tank 40. Tank 40 contains radioactive sludge slurry that was in the tank heel plus sludge slurry that has been transferred from Tank 8. The combination of these two sludge slurries formed Macro Batch 3 or Sludge Batch 2.

The Savannah River Technology Center (SRTC) has analyzed samples of Sludge Batch $2^{1,2}$ in the Shielded Cells Facility. These analyses were completed as part of DWPF process demonstrations and to meet the reporting requirements as specified in the Waste Form Compliance Plan ${ }^{3}$ and the Department of Energy's (DOE) Waste Acceptance Product Specifications (WAPS) ${ }^{4}$. The analytical data collected from the process demonstration have been documented in technical reports $5,6,7,8$.

This report describes the rheological results obtained from samples of the sludge slurry, the Sludge Receipt and Adjustment Tank (SRAT) product, and the Slurry Mix Evaporator (SME) product from the Sludge Batch 2 demonstration. This report also presents the weight percent solids measurements, density determinations, and $\mathrm{pH}$ results. A comparison of the results for the nonradioactive Sludge Batch 2 samples to the results of the radioactive Sludge Batch 2 samples is also presented in this report. Highlights from this report are found below.

1. The flow curve for the radioactive sludge slurry sample exceeded the current DWPF operating region between a shear rate range of $140 \mathrm{~s}^{-1}$ to $640 \mathrm{~s}^{-1}$.

2. The flow curves for the radioactive SRAT and SME samples were within the DWPF operating region.

3. The nonradioactive simulant data collected using the Haake Rotovisco model RV20 (sludge slurry and SME samples) or the ThermoHaake RS150 RheoStress rheometer (sludge slurry samples) could be curve fitted providing a yield stress and consistency dependency based on insoluble solids loading.

4. The nonradioactive simulants cannot be used to predict the behavior (yield stress and consistency) of radioactive samples analyzed in this report. More radioactive data is required at various weight percent insoluble solids and different $\mathrm{pHs}$ to confirm the results of the nonradioactive simulants.

\section{RECOMMENDATION:}

Since a portion of the radioactive sludge slurry flow curve exceeded the DWPF operating region; an evaluation of this data should be performed to determine the impacts to the current DWPF system.

\section{SUGGESTED FUTURE WORK:}

- Determine the differences between the nonradioactive data collected using the Haake Rotovisco model RV20 and ThermoHaake RS150 RheoStress rheometer. This task could be completed using available samples. 
- Collect more data for the nonradioactive and radioactive sludge slurry, SRAT product, and SME product samples varying the $\mathrm{pH}$ and insoluble solids loading. Determine the yield stress and consistency dependency on the insoluble solids loading and $\mathrm{pH}$. Use this data to help define an optimum operating region for the DWPF Chemical Processing Cell.

\subsection{BACKGROUND INFORMATION FOR THE SLUDGE BATCH 2 SAMPLES AND A BRIEF DESCRIPTION OF TASK ACTIVITIES}

Twelve dip samples (220 mL/each dip sample) were obtained from Tank 40 and sent to the SRTC Shielded Cells Facility. The samples were combined and an initial composition of the radioactive sludge slurry was obtained. Since the sludge slurry was unwashed and the Na concentration did not meet the DWPF acceptance criteria, a demonstration of the Tank Farm's Extended Sludge Processing (ESP) was performed by the Waste Processing Technology (WPT) group. The sludge slurry was washed to a target endpoint of $0.55 \mathrm{M} \mathrm{Na}( \pm 0.05 \mathrm{M} \mathrm{Na})$ in the supernate to meet the acceptance criteria of the DWPF. Upon receipt of the washed sludge slurry from WPT, a demonstration of the DWPF "Sludge-Only" flow sheet was performed using approximately one liter of sludge slurry. The DWPF "Sludge-Only" Flow sheet calls for processing radioactive sludge slurry using nitric acid, concentrated formic acid, and frit 200 through the Chemical Processing Cell (CPC) of DWPF. During each step of this process, samples were pulled for characterization including samples for rheological measurement. Details of the CPC demonstration and the characterization of the samples have been published previously ${ }^{5,6}$.

\subsection{ANALYSIS PERFORMED ON THE SLUDGE SLURRY SAMPLES}

This section describes the analytical methods used to determine the weight percent total solids, weight percent dissolved solids in the supernate, and density measurements. This section also presents the calculated values for the insoluble and the soluble solids for the Sludge Batch 2 samples.

\subsection{Total Weight Percent Solids Analysis and Density Determinations for Sludge Slurry, SRAT Product, and SME Product for Sludge Batch 2}

In order to obtain the weight percent solids measurements for the sludge slurry, SRAT product, and SME product, quadruplicate samples of each mixed sample were pipetted out of each sample bottle and placed into labeled PMP $\AA$ beakers. These PMP $\AA$ beakers were weighed and then placed into a drying oven at $115^{\circ} \mathrm{C}$ overnight. Triplicate samples of a $15 \mathrm{wt} . \% \mathrm{NaCl}$ standard solution were also weighed and dried (in labeled PMP $®$ beakers) along with the samples to check the accuracy and precision of the method. All of the samples were allowed to cool for $\sim 5$ minutes before they were weighed. The results of the standard solutions showed good reproducibility and good agreement with the known value of the standard (within 5 $\%$ of the known values). The averages of the calculated results of the weight percent solids for all of the samples are presented in Table 1. The standard deviations (StDev) and the percent relative standard deviation (\%RSD) for the weight percent data are presented in parentheses next to each value in Table 1 respectively.

The density measurements for the sludge slurry, SRAT product, and SME product were completed remotely in the Shielded Cells Facility by using heat sealed pipette tips. The pipette tips are first sealed and then calibrated with water to obtain the volume. Four density measurements were completed for each sample. The sealed pipette tip was first weighed and then a mixed sample was pipetted into the sealed pipette tip. The sealed pipette tip containing the sample was weighed and a density calculated. The results 
of the density for the samples are presented in Table 1. The standard deviations and the percent relative standard deviations for the data are also presented in parentheses next to each value in Table 1 respectively.

Table 1 - Total Weight Percent Solids Analysis and Density Determinations for the Sludge Slurry, SRAT Product, and SME Product

\begin{tabular}{|c|c|c|}
\hline & $\begin{array}{c}\text { Weight Percent } \\
\text { Total Solids }^{\mathbf{a}}\end{array}$ & $\begin{array}{c}\text { Density } \\
\text { Determination }\end{array}$ \\
\hline $\begin{array}{c}\text { Sludge Slurry } \\
\text { Results }\end{array}$ & $\begin{array}{c}18.4 \mathrm{wt} . \% \\
( \pm 3.9 \mathrm{E}-02,2.1 \mathrm{E}-01)\end{array}$ & $\begin{array}{c}1.12 \mathrm{~g} / \mathrm{mL} \\
( \pm 2.3 \mathrm{E}-02,2.1 \mathrm{E} 00)\end{array}$ \\
\hline $\begin{array}{c}\text { SRAT Product } \\
\text { Results }\end{array}$ & $20.2 \mathrm{wt} \%$ & $1.15 \mathrm{~g} / \mathrm{mL}$ \\
$( \pm 1.1 \mathrm{E}-01,5.4 \mathrm{E}-01)$ & $( \pm 4.0 \mathrm{E}-03,3.0 \mathrm{E}-01)$ \\
\hline $\begin{array}{c}\text { SME Product } \\
\text { Results }\end{array}$ & $45.3 \mathrm{wt} . \%$ & $1.36 \mathrm{~g} / \mathrm{mL}$ \\
$( \pm 5.2 \mathrm{E}-01,1.1 \mathrm{E} 00)$ & $( \pm 3.5 \mathrm{E}-02,2.6 \mathrm{E} 00)$ \\
\hline
\end{tabular}

${ }^{a}$ Dried in an oven overnight at $115^{\circ} \mathrm{C}$. Results are the average of four samples. The standard deviations and the percent relative standard deviations for the data are also presented in parentheses next to each value.

${ }^{\mathrm{b}}$ Results are the average of four samples. The standard deviations and the percent relative standard deviations for the data are also presented in parentheses next to each value.

\subsection{Weight Percent Dissolved Solids Analysis and Density Determinations for Sludge Slurry, SRAT Product, and SME Product Supernates for Sludge Batch 2}

Mixed samples of the sludge slurry, SRAT product, and SME product were individually filtered through three separate $0.45 \mu \mathrm{m}$ Nalgene ${ }^{\circledR}$ filters resulting in clear supernates for all three samples. These supernate samples were used to complete the density and the weight percent solids measurements. See Section 3.1 for details concerning the weight percent solids and density measurements. The results of the weight percent solids and density measurements are reported in Table 2. The standard deviations and the percent relative standard deviations for the data are also presented in parentheses next to each value in Table 2 respectively.

Table 2 - Weight Percent Dissolved Solids Analysis and Density Determinations for the Sludge Slurry, SRAT Product, and SME Product Supernates

\begin{tabular}{|c|c|c|}
\hline & $\begin{array}{c}\text { Weight Percent } \\
\text { Dissolved Solids }\end{array}$ & $\begin{array}{c}\text { Density } \\
\text { Determination }\end{array}$ \\
\hline $\begin{array}{c}\text { Sludge Slurry } \\
\text { Results }\end{array}$ & $3.39 \mathrm{wt} \%$ & $1.03 \mathrm{~g} / \mathrm{mL}$ \\
$( \pm 7.3 \mathrm{E}-02,2.1 \mathrm{E} 00)$ & $( \pm 4.0 \mathrm{E}-03,3.5 \mathrm{E}-01)$ \\
\hline $\begin{array}{c}\text { SRAT Product } \\
\text { Results }\end{array}$ & $6.08 \mathrm{wt} \%$ & $1.04 \mathrm{~g} / \mathrm{mL}$ \\
$( \pm 2.1 \mathrm{E}-01,3.4 \mathrm{E} 00)$ & $( \pm 1.3 \mathrm{E}-02,1.2 \mathrm{E} 00)$ \\
\hline $\begin{array}{c}\text { SME Product } \\
\text { Results }\end{array}$ & $7.64 \mathrm{wt} \%$ & $1.04 \mathrm{~g} / \mathrm{mL}$ \\
$( \pm 6.2 \mathrm{E}-02,8.1 \mathrm{E}-01)$ & $( \pm 2.4 \mathrm{E}-03,2.3 \mathrm{E}-01)$ \\
\hline
\end{tabular}

${ }^{a}$ Dried in an oven overnight at $115^{\circ} \mathrm{C}$. Results are the average of four samples. The standard deviations 
and the percent relative standard deviations for the data are also presented in parentheses next to each value.

${ }^{\mathrm{b}}$ Results are the average of four samples. The standard deviations and the percent relative standard deviations for the data are also presented in parentheses next to each value.

\subsection{Calculation of Insoluble Solids and Soluble Solids for the Slurry Sample, SRAT Product, and SME Product for Sludge Batch 2}

Once the total weight percent solids and the weight percent dissolved solids values were obtained for the samples, the soluble and insoluble weight percent solids were calculated. These values are calculated by using the following equations ${ }^{9}$ :

Equation 1: $\quad \mathrm{W}_{\mathrm{is}}=\left(\mathrm{W}_{\mathrm{ts}}-\mathrm{W}_{\mathrm{ds}}\right) /\left(1-\mathrm{W}_{\mathrm{ds}}\right)^{9}$

Equation 2: $\quad \mathrm{W}_{\mathrm{ss}}=\mathrm{W}_{\mathrm{ts}}-\mathrm{W}_{\mathrm{is}}{ }^{9}$

$\mathrm{W}_{\mathrm{ds}}-$ Weight fraction of dissolved solids (weight of dissolved solids/weight of supernate)

$\mathrm{W}_{\mathrm{ts}}$ - Weight fraction of total solids (weight of total solids/weight of sludge slurry)

$\mathrm{W}_{\text {is }}$ - Weight fraction of insoluble solids (weight of insoluble solids/weight of sludge slurry)

$\mathrm{W}_{\mathrm{ss}}$ - Weight fraction of soluble solids (weight dissolved solids/weight of sludge slurry)

An example using the values obtained for the sludge slurry sample can be found below.

Substituting the values of the measured variables:

$$
\begin{aligned}
& \text { Sludge Slurry Sample } \\
& \mathrm{W}_{\mathrm{ds}}=0.0339 \\
& \mathrm{~W}_{\mathrm{ts}}=0.184 \\
& \mathrm{~W}_{\mathrm{is}}=? \\
& \mathrm{~W}_{\mathrm{ss}}=?
\end{aligned}
$$

Solving Equation 1:

Combined Sludge Slurry Sample

$\mathrm{W}_{\text {is }}=(0.184-0.0339) /(1-0.0339)$

$\mathrm{W}_{\text {is }}=0.1554$

Converting to weight percent (multiply 100):

Combined Sludge Slurry Sample

$\mathrm{W}_{\mathrm{is}}=15.54 \mathrm{wt} \%$

Solving Equation 2:

Combined Sludge Slurry Sample

$\mathrm{W}_{\mathrm{ss}}=\mathrm{W}_{\mathrm{ts}}-\mathrm{W}_{\mathrm{is}}$

$\mathrm{W}_{\mathrm{ss}}=0.184-0.1554$

$\mathrm{W}_{\mathrm{ss}}=0.0286$ 
Converting to weight percent (multiply 100):

Combined Sludge Slurry Sample

$\mathrm{W}_{\mathrm{ss}}=2.86 \mathrm{wt} . \%$

Table 3 presents the calculated values for the insoluble and soluble solids for the sludge slurry, SRAT product, and SME product for Sludge Batch 2.

Table 3 - Calculated Values for the Insoluble and Soluble Solids for the Sludge Slurry, SRAT Product, and SME Product for Sludge Batch 2

\begin{tabular}{|c|c|c|}
\hline & Insoluble Solids & Soluble Solids \\
\hline $\begin{array}{c}\text { Sludge Slurry } \\
\text { Results }\end{array}$ & $15.54 \mathrm{wt} . \%$ & $2.86 \mathrm{wt} . \%$ \\
\hline $\begin{array}{c}\text { SRAT Product } \\
\text { Results }\end{array}$ & $15.03 \mathrm{wt} . \%$ & $5.17 \mathrm{wt} . \%$ \\
\hline $\begin{array}{c}\text { SME Product } \\
\text { Results }\end{array}$ & $40.78 \mathrm{wt} . \%$ & $4.52 \mathrm{wt} . \%$ \\
\hline
\end{tabular}

\section{4 pH Measurements for the Sludge Slurry, SRAT Product, and SME Product for Sludge Batch 2}

Measurements of the $\mathrm{pH}$ were completed for the three samples. Prior to the $\mathrm{pH}$ measurements of the samples, the $\mathrm{pH}$ probe was calibrated with a 7 buffer solution and a 10 buffer solution and checked with a 4 buffer solution. This was completed to make sure the $\mathrm{pH}$ probe was responding as expected. The $\mathrm{pH}$ of the sludge slurry, SRAT product, and SME product samples were 11.2, 6.49, and 6.29, respectively.

\subsection{RADIOACTIVE RHEOLOGICAL MEASUREMENTS OF SLUDGE SLURRY, SRAT PRODUCT, AND SME PRODUCT SAMPLES FOR SLUDGE BATCH 2}

\subsection{Overview}

All of the rheological measurements for the sludge slurry samples were obtained using the Haake RV30/M5 system located in Cell 2 of the Shielded Cells Facility. The specifications for the instrument can be found in the section below called "Summary of the Instrument's Specifications Used to Complete the Rheological Measurements". A Newtonian oil standard ( $\left.29 \mathrm{cp} @ 25^{\circ} \mathrm{C}\right)$ was used to check the instrument's response prior to the start of the sludge slurry measurements and after the last sludge slurry measurement. The oil standard check was performed to ensure that the instrument was responding as expected. The MVI rotor was used in all of the measurements obtained.

The MVI rotor was selected because it is primarily used for rheological measurements of fluids working in the medium shear rate range ${ }^{10}$. The MVI rotor has been traditionally used to quantify the flow properties of HLW sludge slurries. The gap between the rotor and the cup is large enough not to be impacted by the sludge particles. The top and bottom surfaces of the MVI rotor are recessed. When a sample is loaded for measurement, an air gap is retained in the bottom recess of the rotor. This air gap provides a momentum buffer between the fluid and the rotor, where no torque is measured, eliminating or minimizing 
"end effects" as long as the air gap is intact after the measurement is complete. A breach of this air gap is detected by visually inspecting the bottom recess for sample residue. The top surface of the rotor is recessed to accommodate excess sample when the sample is loaded for measurement. After each sludge slurry measurement, the bottom recess of the rotor was examined visually for sample residue. No sample residue was found in the bottom recess of the rotor, indicating the air gap remained intact during the measurement. All of the rheological measurements for this study were conducted at $27^{\circ} \mathrm{C}$. Performing measurements at elevated temperatures above $27^{\circ} \mathrm{C}$ were not considered, due to the inability to prevent the evaporation of water from the samples.

\subsection{Summary of the Instrument's Specifications Used to Complete the Rheological Measurements}

The Haake RV30/M5 system is a controlled rate rheometer that can be operated remotely in the Shielded Cells environment. A water bath/circulator is used to supply water and maintain the temperature of the water jacket that surrounds the sample cup. The M5 measuring head can be equipped with different sample cups and rotors depending on the type of fluid to be analyzed. The technical specifications for the RV30/M5 system are listed in Table 4. The shear rate and shear stress ranges provided (in Table 4) are the capabilities of the various rotors that can be used with the M5 measuring head.

\section{Table 4 - Technical Specifications for the System ${ }^{10}$}

\begin{tabular}{|ll|}
\hline Speed Range: & 5E-02 to $5 \mathrm{E} 02 \mathrm{rpm}$ \\
Shear Rate Range: & 4E-03 to 4E04 s-1 \\
Shear Stress Range: & 2E-01 to 7E04 Pa \\
Temperature Range: & Depends on Water Bath /Circulator \\
Torgue Range. & 0049 to $49 \mathrm{Ncm}$ \\
\hline
\end{tabular}

The error in the measured shear stress is $0.5 \%$ of full span (100\% Tau) and the error for the measured shear rate is $0.5 \%$ of the reading. Table 5 provides the maximum shear rate, maximum shear stress, and physical dimensions associated with MVI rotor.

Table 5 - Maximum Shear Rate, Maximum Shear Stress, and Physical Dimensions Associated with the MVI Rotor ${ }^{10}$

$\underline{\text { MVI Rotor - Maximum Tau (Pa) and D (1/s) }}$

$100 \% \mathrm{Tau}=322 \mathrm{~Pa}$

$100 \% \mathrm{D}=1170(1 / \mathrm{s})$

$\underline{\text { MVI Rotor - Physical Dimensions }}$

Inner Cylinder (Rotor)

Radius $\mathrm{R}_{\mathrm{i}}-20.04 \mathrm{~mm}$

Height $\mathrm{L}-60 \mathrm{~mm}$

Outer Cylinder (Cup)

Radius $\mathrm{R}_{\mathrm{a}}-21 \mathrm{~mm}$

Radii Ratio $\left(\mathrm{R}_{\mathrm{a}} / \mathrm{R}_{\mathrm{i}}\right)-1.05$

Gap Width - 0.96 mm 
$\mathrm{Cl}$ factor (Torque correction factor which incorporates rotor end effects) -1.0053

\subsection{Programming of the RV30}

Different programming times and shear rate ranges were selected based on the visual observations of the sludge slurry samples. Table 6 contains the different programming times and shear rate ranges for the sludge slurry samples and the oil standard. No hold times at the maximum shear rate were programmed for any of these measurements due to the nature of the samples and the time required to load the sample into the instrument.

Table 6 - Programming Times and Shear Rate Ranges Selected for the Sludge Slurry, SRAT Product, SME Product, and Standard Oil Samples

\begin{tabular}{|c|c|c|c|c|}
\cline { 2 - 5 } \multicolumn{1}{c|}{} & \multicolumn{3}{|c|}{ Shear Rate Range and Time } \\
\hline \multirow{2}{*}{ Up Curve } & Sludge Slurry & SRAT Product & SME Product & Standard Oil \\
\hline \multirow{2}{*}{ Down Curve } & $\begin{array}{c}0-800 \mathrm{~s}^{-1}, \\
4 \text { minutes }\end{array}$ & $\begin{array}{c}0-800 \mathrm{~s}^{-1}, \\
4 \text { minutes }\end{array}$ & $\begin{array}{c}0-1100 \mathrm{~s}^{-1}, \\
5 \text { minutes }\end{array}$ & $\begin{array}{c}0-1100 \mathrm{~s}^{-1}, \\
3 \text { minutes }\end{array}$ \\
\hline & $\begin{array}{c}800-0 \mathrm{~s}^{-1}, \\
4 \text { minutes }^{*}\end{array}$ & $\begin{array}{c}800-0 \mathrm{~s}^{-1}, \\
4 \text { minutes }\end{array}$ & $\begin{array}{c}1100-0 \mathrm{~s}^{-1}, \\
5 \text { minutes }\end{array}$ & $\begin{array}{c}1100-0 \mathrm{~s}^{-1}, \\
3 \text { minutes }\end{array}$ \\
\hline
\end{tabular}

\subsection{Preparation of the Sludge Slurry, SRAT Product, and SME Product Samples for Measurement and the Results of the Uncorrected Flow Curves}

To prepare the samples for measurement, each sample was mixed and poured into the measuring cup. While pouring the samples into the measuring cup, visual observations of the samples were noted. The sludge slurry sample and the SME product sample had a foamy appearance. Once the sample was poured into the measuring cup, the in-cell camera was used to look inside the cup. Several air bubbles appeared to be popping at the surface layer of the sample. Some of the air bubbles were large $(\sim 1 / 4$ to $1 / 2$ inches in diameter) while others were small ( 1/16 inches in diameter). Upon the first initial attempt of measuring both of these samples, the results of the flow curves indicated that a continuum fluid was not present. These results could not be technically interpreted or fit to any rheological model. The reason for these atypical results was attributed to the air bubbles in the samples. To resolve this issue, the samples were mixed again and a pipette tip was used to carefully stir the samples to assist the larger air bubbles to come to the surface and pop. The measuring cup was loaded into the instrument and the measurements were completed successfully. No large air bubbles were noted for the SRAT product sample. Pictures of the sludge slurry, SRAT product, and SME product samples (in the measuring cup) were taken with the in-cell camera and are presented in Figure 1. From the pictures in Figure 1, one can see that there are distinct differences in the appearance of the surface of the samples. The changes in the surfaces of the samples were attributed to the various additions of acids and frit made during the DWPF process.

The raw data obtained from the rheometer (up flow curves only) for the sludge slurry, SRAT product, and SME product samples are plotted in Figure 2, Figure 3, and Figure 4 respectively. Figures 2 through 4 were curve fitted using the Bingham Plastic model and were plotted against the DWPF operating region for each sample. The DWPF operating region was created for each sample by using the Bingham Plastic 
model fit of the upper and lower ranges for consistency and yield stress for the sludge slurry, SRAT product, and SME product found in reference DPSTD-80-38-2 ${ }^{11}$. Figure 5 compares the rheological results for the samples with each other. Oil standard results are found in Appendix A. Since the curve fit of the rheological data obtained for these samples were performed on the up curves, it was decided to omit all of the down curves for the samples. The down curves for the three samples were slightly lower than the up curves. This hysteresis could be due to solids settling out of the shearing zone or due to the structure of the fluid breaking down (thixotropic), or migration of the solids away from the rotating MVI rotor leaving a clear fluid interface.

Figure 1 - Pictures of the Sludge Slurry, SRAT Product, and SME Product in the Measuring Cup
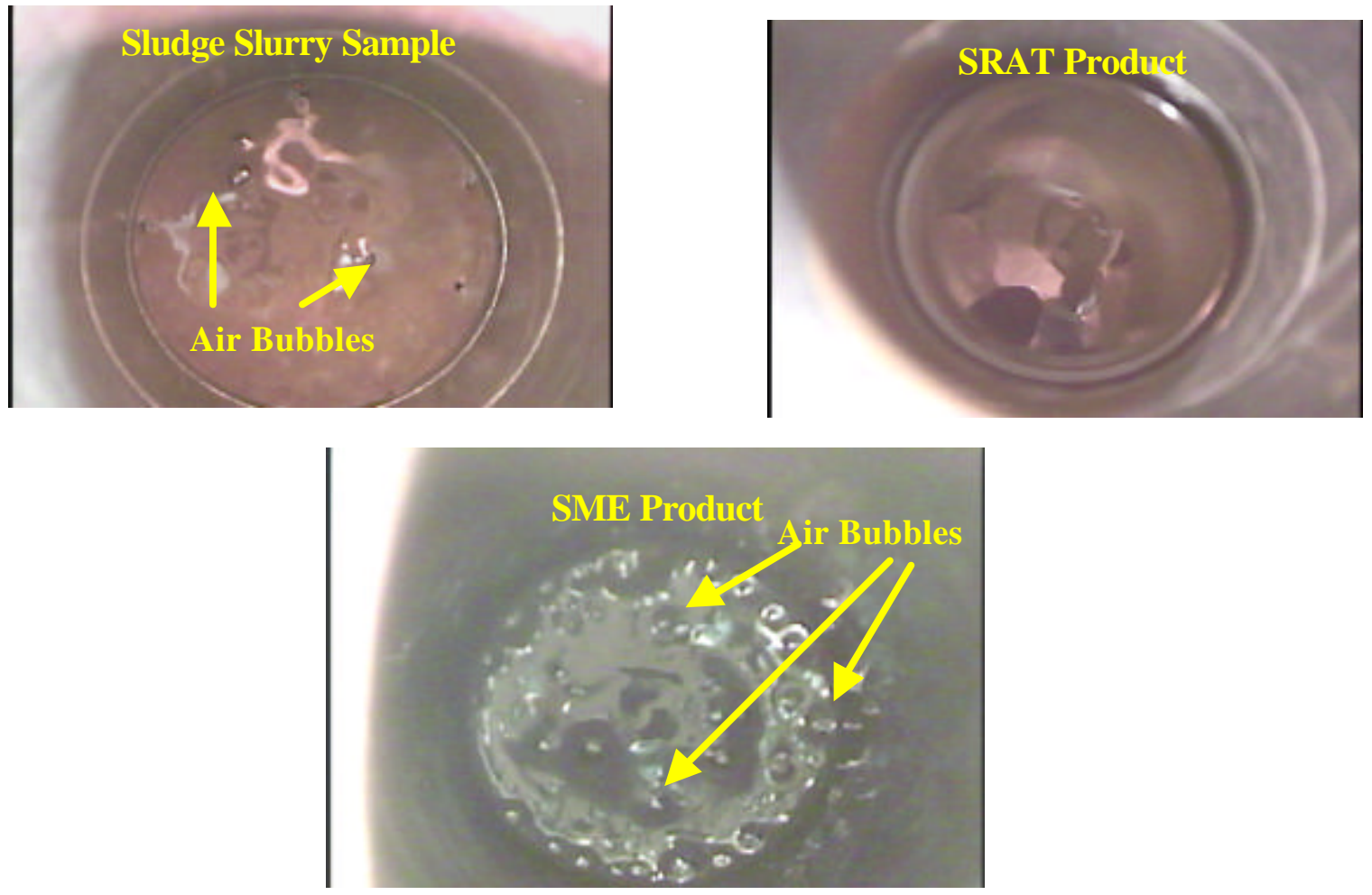

Figure 2 - Uncorrected Flow Curve for the Sludge Batch 2 Sludge Slurry Sample

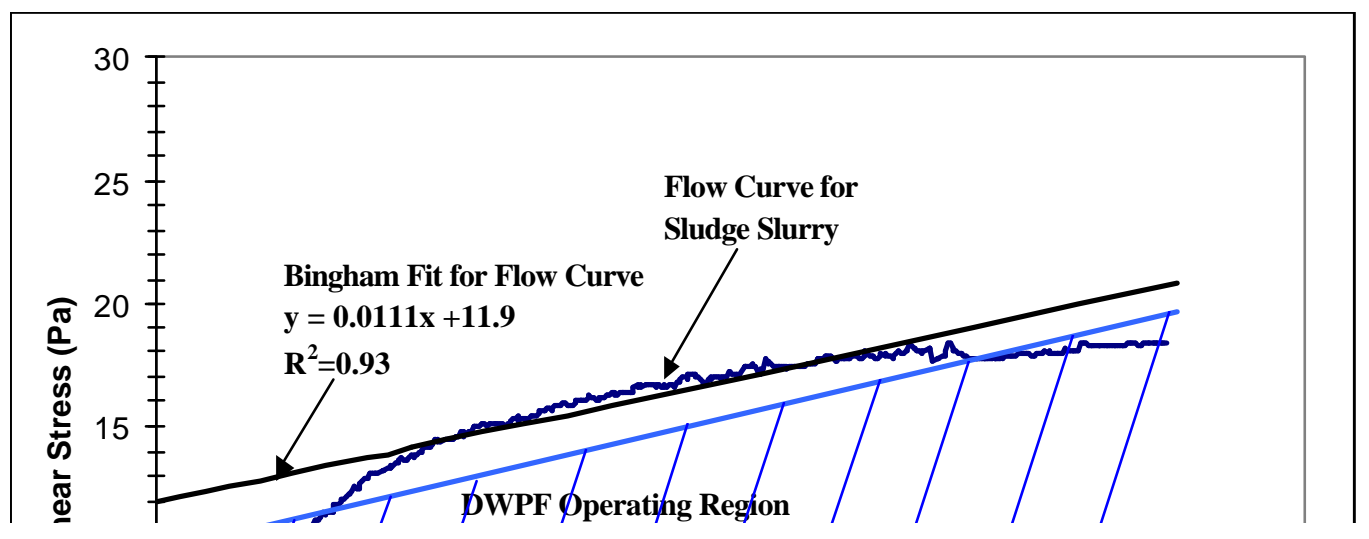


The sludge slurry in the DWPF is pumped at a wide range of flow rates through pipes of various diameters. As seen in Figure 2, a portion $\left(140 \mathrm{~s}^{-1}\right.$ to $\left.640 \mathrm{~s}^{-1}\right)$ of the flow curve is slightly outside of the DWPF operating region for the sludge slurry. This data will require further evaluation to determine the impact to the current DWPF processes handling sludge slurry. When performing this evaluation, the other variable to consider is the weight percent total solids of the incoming sample to DWPF. The weight percent total solids for the Shielded Cells sample (18.4 wt.\%) is approaching the limit of 19 weight percent total solids for the incoming feed for DWPF. Any dilution to this sample would probably shift the flow curve down (lower yield stress) and to the right (lower consistency).

The Bingham Plastic model was used to curve fit the data set collected from $100 \mathrm{~s}^{-1}$ to $800 \mathrm{~s}^{-1}$ presented in Figure 2. Based on the data in Figure 2, the flow curve appears to climb the y-axis and then deviates from the $y$-axis at $25 \mathrm{~s}^{-1}$. Based on the deviation from the y-axis, the actual yield stress of the sample appears to be between 3-4 Pa versus 11.9 Pa obtained from the Bingham Plastic curve fit. In this particular case, selecting the Bingham Plastic model to fit the data is hydraulically conservative from a yield stress measurement standpoint. However, the Bingham Plastic model does not provide an accurate analysis for the data collected from $0 \mathrm{~s}^{-1}$ to $140 \mathrm{~s}^{-1}$. To correct this problem, other rheological models could be used to account for the lower yield stress and fit the complete flow curve.

\section{Figure 3 - Uncorrected Flow Curve for the Sludge Batch 2 SRAT Product Sample}

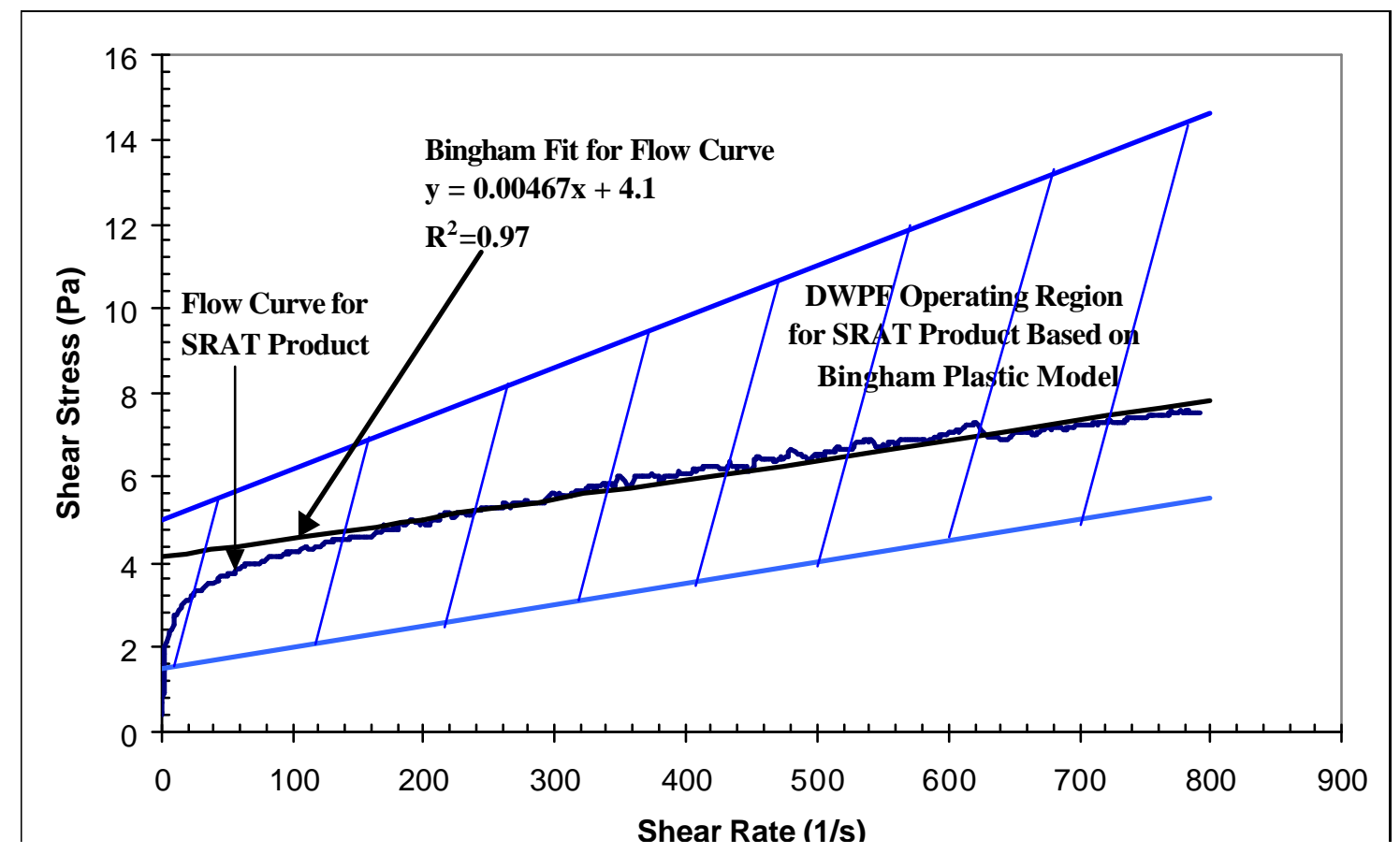


As seen in Figure 3, the Bingham Plastic model provided a good fit for the data collected from a shear rate range of $100 \mathrm{~s}^{-1}$ to $800 \mathrm{~s}^{-1}$. The flow curve for the SRAT product sample is within the DWPF operating region for the SRAT product. Although the curve fit of the data predicted a higher yield stress, the Bingham Plastic model provided a better fit of the data than it did for Figure 2 and is hydraulically conservative. 
Figure 4 - Uncorrected Flow Curve for Sludge Batch 2 SME Product Sample

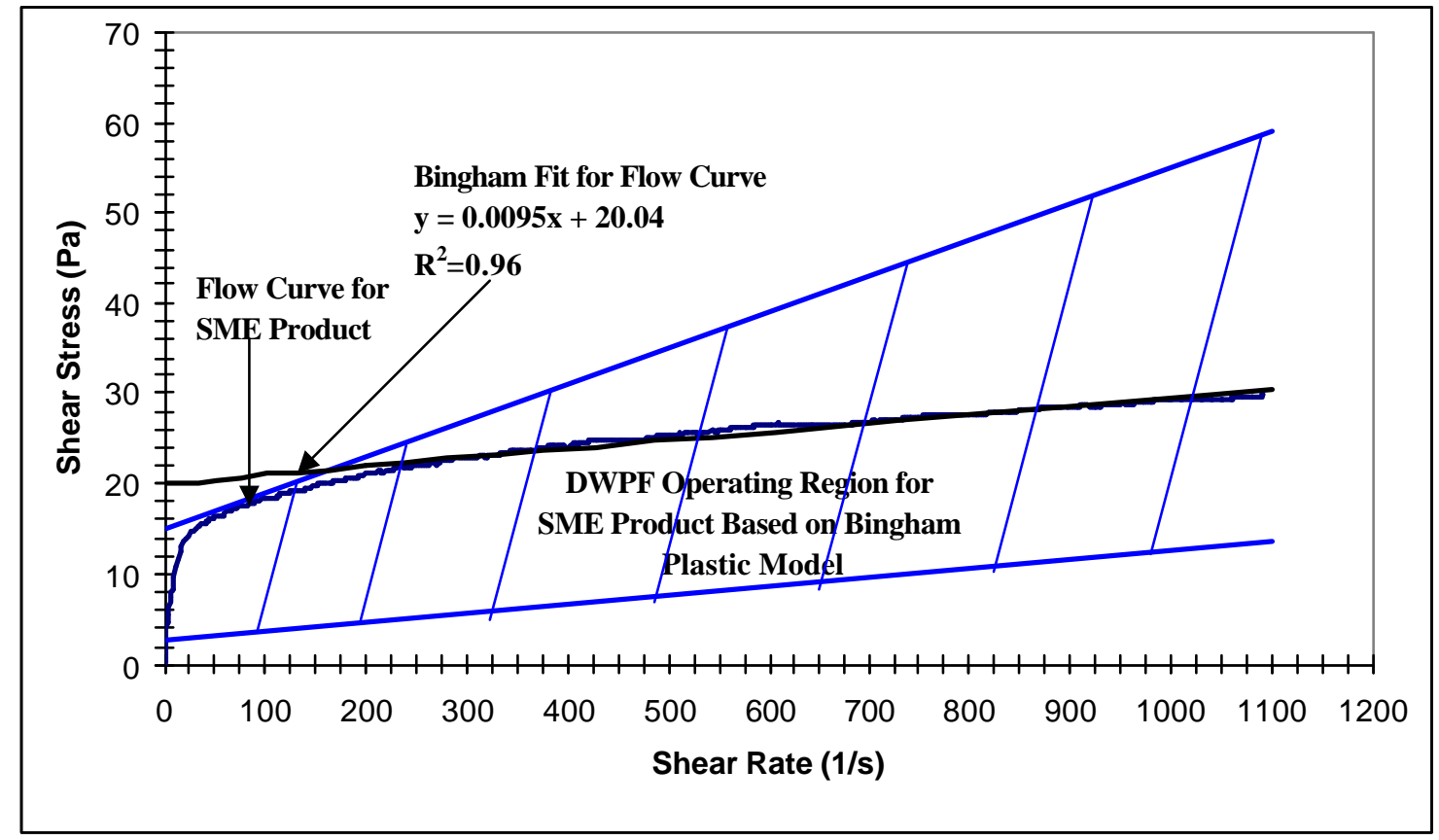

The flow curve presented in Figure 4 is within the DWPF operating region for the SME product. The Bingham Plastic curve fit of the data from the shear rate range of $150 \mathrm{~s}^{-1}$ to $1100 \mathrm{~s}^{-1}$ indicates that the predicted yield stress has been exceeded. This is hydraulically conservative, because the actual yield stress of the sample appears to be lower than that predicted from the Bingham Plastic model and the flow curve never exceeded the expected operating region.

Figure 5 -Comparison of the Uncorrected Flow Curves for Sludge Slurry, SRAT Product, and SME Product Samples

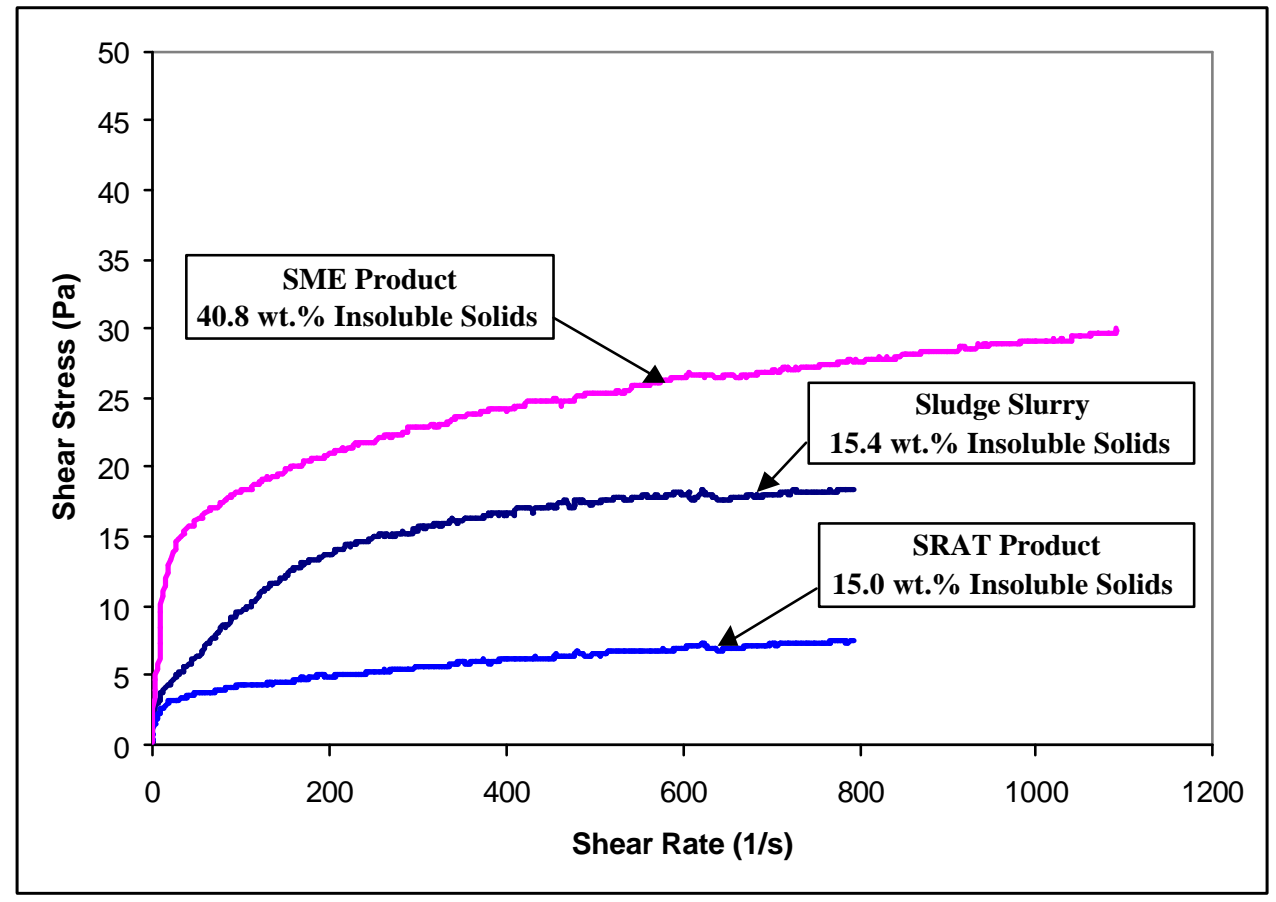


Upon comparing the flow curves in Figure 5, a significant difference is noticed between the three samples. The major difference could be attributed to the $\mathrm{pH}$ of the samples (see Section 3.4) as well as the insoluble and soluble solids for each sample (see Table 3). As the insoluble solids increase, an increase in the shear stress is seen with increasing shear rate. D.C. Koopman has previously studied the effect of increasing insoluble solids for Sludge Batch 2 nonradioactive slurries ${ }^{12}$. D.C. Koopman's data for the sludge slurry, SRAT product, and SME product samples will be compared to the radioactive data collected for Sludge Batch 2 in Section 5.0.

Multiple flow curves were obtained for each sample. For all three samples, the first up curve obtained for each series of samples was used and is presented in the above figures. The other flow curves obtained for the sludge slurry and SRAT product samples were lower and repeatable, except for the SME product sample. In the case of the sludge slurry and SRAT product samples, the samples were not loaded into the cup each time for each measurement. The lower responses obtained for the sludge slurry and SRAT product measurements could be due to solids settling out over time or the break down of the initial structure of the sample (thixotropic). In the case of the SME product sample, it continually dropped after each measurement. This was due to the frit (vitrified glass formers) settling out over time. Upon pouring the SME sample back into the sample bottle, a lot of solids were noted at the bottom of the measuring cup. The data plotted in Figures 2 through 4 are not corrected (for non-Newtonian behavior) and are plotted as the raw data obtained from the instrument (treats fluids as Newtonian). The raw data for the up curves are provided in Appendix B. Appendix A contains the results of the up flow curves for the Newtonian oil standard used to check the operability of the instrument. No correction is required for the Newtonian oil standard. Presented below are the Bingham Plastic model fits for the data presented in Figure 2, Figure 3, and Figure 4. The Bingham plastic model is defined as:

$\mathrm{Tau}=\mathrm{Tau}_{\mathrm{o}}+\eta \mathrm{D}$ or $\left\{\tau=\tau_{\mathrm{o}}+? / 100 \dot{\gamma}\right\}$

Where: $\quad$ Tau $(\tau)=$ Shear stress $\left\{\right.$ Dynes $\left./ \mathrm{cm}^{2}\right\}$

$\operatorname{Tau}_{\mathrm{o}}\left(\tau_{\mathrm{o}}\right)=$ Shear stress at $\mathrm{D}=0 \mathrm{~s}^{-1}\left\{\right.$ Dynes $\left./ \mathrm{cm}^{2}\right\}$ or Yield Stress

$\eta=$ Consistency $\{$ centipoise $=\mathrm{cp}\}$

$\mathrm{D}(\dot{\gamma})=$ shear rate $\left\{\mathrm{s}^{-1}\right\}$

This model was linearly regressed to the following shear rate ranges for Figures 2, 3, and 4: $150 \mathrm{~s}^{-1}$ to 620 $\mathrm{s}^{-1}$ for Figure 2, $100 \mathrm{~s}^{-1}$ to $800 \mathrm{~s}^{-1}$ for Figure 3, and $150 \mathrm{~s}^{-1}$ to $1100 \mathrm{~s}^{-1}$ for Figure 4. The results of the Bingham Plastic model, for Figure 2 through Figure 4, are presented in Table 7.

Table 7 - Bingham Plastic Model Results for Figure 2, Figure 3, and Figure 4

\begin{tabular}{|c|c|c|c|c|}
\hline Figure & $\frac{\text { Fitted Range }}{\left(\mathrm{s}^{-1}\right)}$ & $\begin{array}{c}\underline{\mathbf{t}}_{0} \\
(\text { Dynes/cm²) }\end{array}$ & $\stackrel{?}{\stackrel{?}{c p})}$ & $\underline{\mathbf{R}}^{2}$ \\
\hline 2 & $150-620$ & 119 & 11.1 & 0.93 \\
\hline 3 & $100-800$ & 41 & 4.67 & 0.97 \\
\hline 4 & $150-1100$ & 200 & 9.50 & 0.96 \\
\hline
\end{tabular}




\subsection{COMPARISON OF THE RADIOACTIVE SLUDGE BATCH 2 SAMPLES TO THE NONRADIOACTIVE SLUDGE BATCH 2 SAMPLES}

As noted in Section 4.4, the majority of the measurements for Sludge Batch 2 nonradioactive samples have been completed and documented by D.C. Koopman ${ }^{12}$. The remainder of the nonradioactive Sludge Batch 2 measurements (sludge slurry and SRAT product) conducted by D.C. Koopman will be documented in this report. The unpublished flow curves and description of the instrument used to perform the remainder of the Sludge Batch 2 nonradioactive measurements (sludge slurry and SRAT product) can be found in Appendix C. The raw data for the up curves are presented in Appendix D. This section will compare the results obtained for the radioactive samples to the nonradioactive samples. No attempts have been made to correct either set of data for geometry, non-Newtonian behavior, slip, etc. The data presented in the tables below are the raw data obtained from the instrument fitted to a Bingham plastic model.

For the nonradioactive sludge slurry and SRAT product samples, the Haake Rotovisco model RV20 and ThermoHaake RS150 RheoStress rheometer were used with the MVI rotor/MV cup and Z41 cylinder/DZ43 cup respectively. The nonradioactive SME product samples used the Haake Rotovisco model RV20 with the MVII rotor/MV cup. The system and rotor selection for the radioactive samples is documented in Section 4.1.

Table 8, Table 9, and Table 10 present a summary of the sludge slurry, SRAT product, and SME product results, respectively, obtained from the nonradioactive and the radioactive samples. The results of these samples were then compared to the DWPF operating region in the tables. Each table includes weight percent solids, insoluble solids, yield stress, consistency, and $\mathrm{pH}$. If a value is not available, "N/A" is used in the table.

Table 8 - Summary of the Results Obtained from the Nonradioactive and Radioactive Sludge Slurry Samples for Sludge Batch 2 Compared to the DWPF Operating Region

\begin{tabular}{|c|c|c|c|c|c|}
\hline Sample ID & $\begin{array}{l}\text { Total Solids } \\
\text { (wt.\%) }\end{array}$ & $\begin{array}{c}\text { Insoluble Solids } \\
\text { (wt.\%) }\end{array}$ & $\begin{array}{l}\text { Yield Stress } \\
\left(\text { dynes } / \mathrm{cm}^{2}\right)\end{array}$ & $\begin{array}{l}\text { Consistency } \\
\text { (cp) }\end{array}$ & pH \\
\hline $\begin{array}{c}\text { Tank 8/40 Blend } \\
\text { (nonradioactive sample)* }^{12}\end{array}$ & 15.9 & 13.2 & 36 & 8.5 & 10.3 \\
\hline $\begin{array}{c}\text { GFPS**-SRAT-165-1 } \\
\text { (nonradioactive sample) }\end{array}$ & 13.5 & 10.8 & 17 & 3.6 & 10.6 \\
\hline $\begin{array}{c}\text { GFPS } * * \text {-SRAT-165-2 } \\
\text { (nonradioactive sample) }\end{array}$ & 16.8 & 14.2 & 49 & 5.8 & 10.6 \\
\hline $\begin{array}{l}\text { GFPS } * * \text {-SRAT-164-1 } \\
\text { (nonradioactive sample) }\end{array}$ & 17.1 & 14.5 & 51 & 6.0 & 10.7 \\
\hline $\begin{array}{c}\text { GFPS**-SRAT-164-3 } \\
\text { (nonradioactive sample) }\end{array}$ & 18.5 & 15.9 & 76 & 7.9 & 10.7 \\
\hline $\begin{array}{c}\text { Sludge Batch } 2 \text { Sludge Slurry } \\
\text { Sample } \\
\text { (radioactive sample) }\end{array}$ & 18.4 & 15.5 & $119^{\mathrm{a}}$ & 11.1 & 11.2 \\
\hline DWPF Operating Region ${ }^{11}$ & $13-19$ & N/A & $25-100$ & $4-12$ & N/A \\
\hline
\end{tabular}

*Feed used for the small-scale nonradioactive runs at TNX

**GFPS - Glass Feed Preparation System

${ }^{\text {a }}$ Data is outside of the DWPF operating region

As seen in Table 8, it appears that the radioactive sample and all but one of the nonradioactive samples meet the DWPF operating region for consistency. However, a portion of the flow curve presented in Figure 2 for the radioactive sludge slurry exceeds the DWPF operating region (for a shear rate of $140 \mathrm{~s}^{-1}$ to $640 \mathrm{~s}^{-1}$ ). This is a 
case where comparing the data using a tabular format could lead one to believe that the entire flow curve for the radioactive sample was outside the DWPF operating region. To avoid making erroneous assumptions, it is recommended that the flow curve generated for each type of sample (sludge slurry, SRAT product, and SME product) be plotted against the appropriate DWPF operating region (discussed in Section 4.4).

To make sure that the flow curves for the nonradioactive samples did not display the same behavior as the radioactive sample, the flow curves for the nonradioactive samples were plotted against the DWPF operating region. The plot for the nonradioactive samples can be found in Appendix C, Figure $\mathrm{C}-2$. The results plotted in Figure $\mathrm{C}$ - 2 indicate that all but one of the flow curves was within the DWPF operating region. The entire flow curve for Sample ID GFPS-SRAT-165-1 was found to be below the DWPF operating region. This could be attributed to the low weight percent total solids of the sample. The results presented in Figure $\mathrm{C}-2$ are also consistent with the results presented in Table 8 .

The yield stress measurements presented in Table 8 indicate that the radioactive sample exceeds the maximum DWPF operating region yield stress and Sample ID GFPS-SRAT-165-1 is below the minimum DWPF operating region yield stress. The reason for the radioactive sample exceeding the DWPF yield stress has been discussed previously in Section 4.4. The reason for the nonradioactive sample being below the DWPF yield stress is attributed to the low weight percent total solids of the sample. The other conclusion that can be made by studying the data in Table 8 is that as the insoluble solids content is increased the yield stress and the consistency also increase. These data are consistent with previous work completed on nonradioactive and radioactive sludge slurries. ${ }^{13,14}$ The yield stress data and consistency data for the nonradioactive and radioactive sludge slurry samples are depicted graphically in Figures 6 and 7 respectively.

\section{Figure 6 - Yield Stress $\left(\right.$ Dynes $\left./ \mathrm{cm}^{2}\right)$ Dependence on Insoluble Weight Percent Solids for the Sludge Slurry}

Note: Curve Fit for

Nonradioactive

Measurements Only

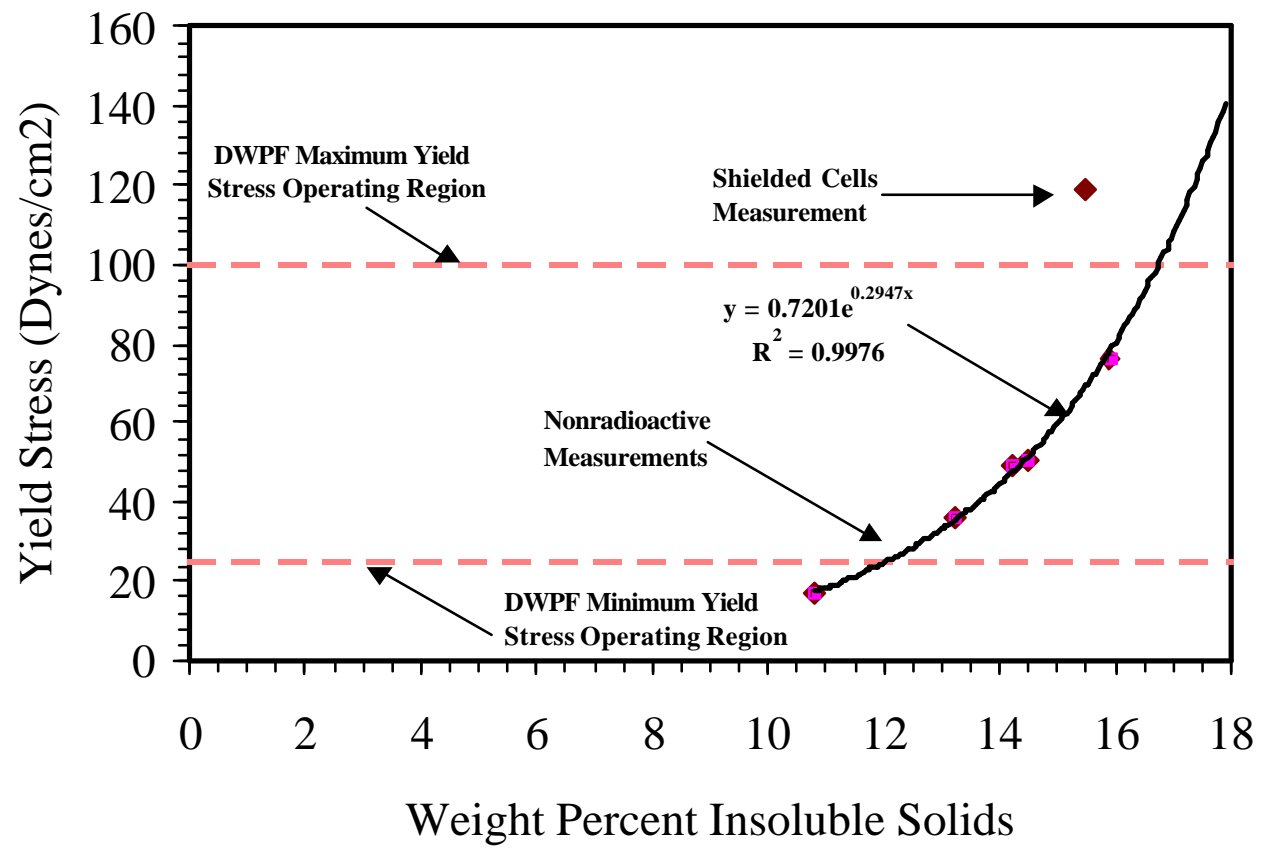


Westinghouse Savannah River Company

Savannah River Technology Center
WSRC-TR-2002-00302

Page 20 of 64

The yield stress data for the nonradioactive rheological measurements were curve fitted. Since only one yield stress measurement was obtained for the radioactive sample, and it was clearly outside of the data set collected for the nonradioactive samples, it was not included in the curve fit. The curve fit of the nonradioactive data provided an equation to predict yield stress for those sludge slurry samples with an insoluble solids content of 10.8 to 15.9 weight percent. This equation can also be used to determine the weight percent insoluble solids of the sludge slurry sample at the DWPF minimum and maximum yield stress operating regions. Inputting the DWPF minimum yield stress $\left(25\right.$ dynes $/ \mathrm{cm}^{2}$ ) value into the equation yielded a value of $12.0 \mathrm{wt} . \%$ insoluble solids.

Although the equation has not been validated for a nonradioactive sludge slurry sample with an insoluble solids loading greater than 15.9, an extrapolation of the curve can be made to determine the insoluble solids loading at the maximum yield stress. Inputting the DWPF maximum yield stress $\left(100 \mathrm{dynes} / \mathrm{cm}^{2}\right)$ value into the equation yielded a value of $16.7 \mathrm{wt} . \%$ insoluble solids. The data obtained at the DWPF maximum yield stress value should be used with caution and should be verified by a rheological measurement. Unfortunately, no correlation could be made for predicting the behavior of the yield stress for the radioactive sludge slurry sample using the available

nonradioactive data. The reason for this was due to a lack of data for the radioactive sample at different weight percent insoluble solids.

Figure 7 - Consistency (Centipoise) Relationship to Insoluble Weight Percent Solids for the Sludge Sluner

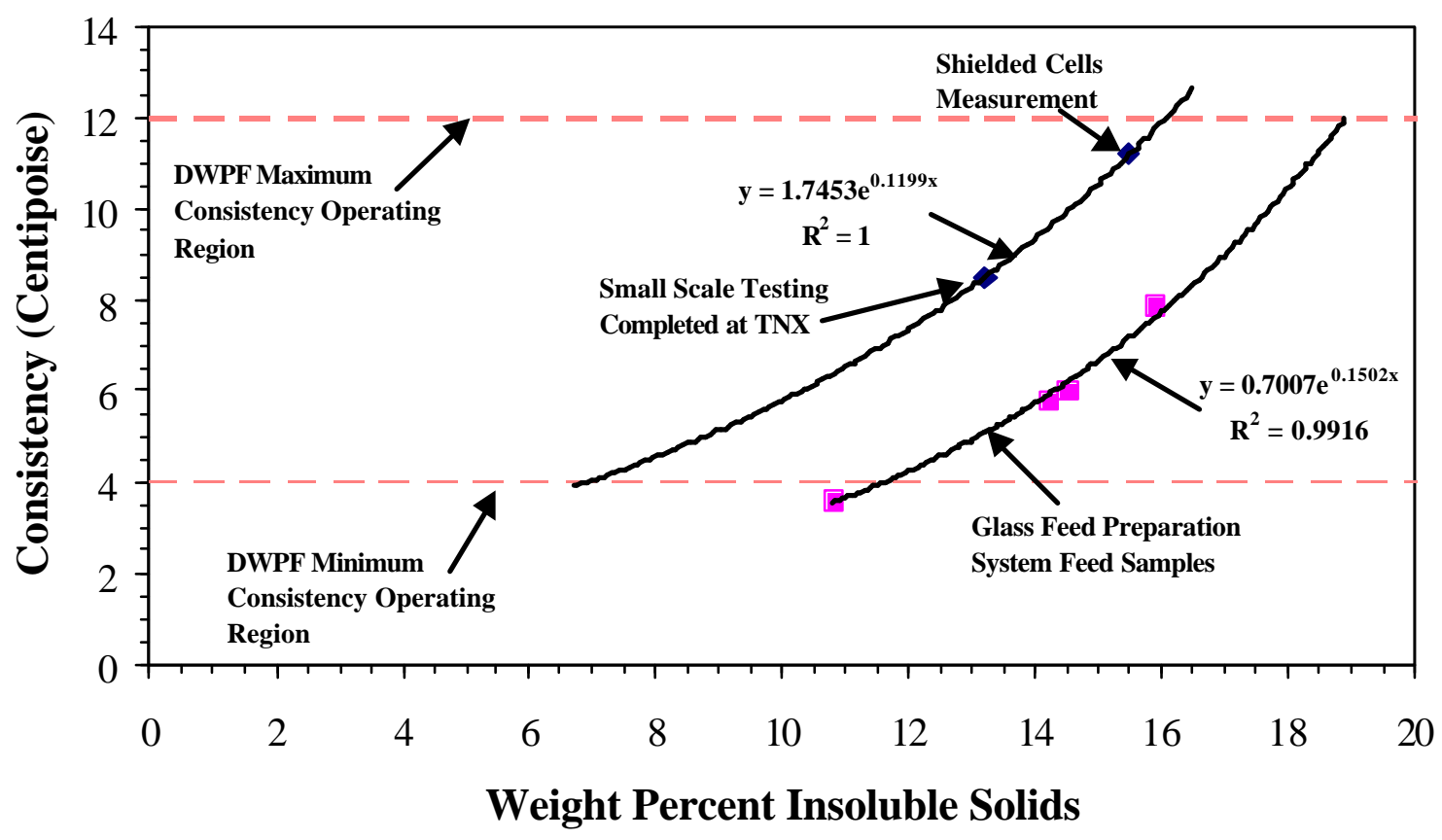

Consistency data in Table 8 were fitted with two different curve fits and are shown in Figure 7. The data used to generate the bottom curve were collected using the ThermoHaake RS150 RheoStress rheometer. The data used to generate the top curve were collected using the Haake Rotovisco model RV20/M5 (nonradioactive sample) and the RV30/M5 systems (radioactive sample). These systems were exactly the same from a geometry perspective; the only difference was the controller (Haake RV20/RV30). Although only two data points were collected using these systems, the data points appear to yield higher consistency results than the ThermoHaake RS150 RheoStress 
rheometer used to obtain the GFPS data. The reason for this difference is unknown at this time and would require further investigation. For both curves, as the insoluble solids content increases the viscosity increases. Using the curve fit equations $\left(y=A e^{B x}\right)$; the insoluble solids loading for a sample can be calculated based on the maximum and minimum DWPF consistency operating region. To perform these calculations both the top and bottom curves were extrapolated for the maximum case and only the top curve was extrapolated for the minimum case. The weight percent insoluble solids loading based on the maximum and minimum DWPF consistency for the top curve fit are 16.1 and 6.9, respectively. The weight percent insoluble solids loading based on the maximum and minimum DWPF consistency for the bottom curve fit are 18.9 and 11.6, respectively. The values obtained from the extrapolation of the curves should be used with caution since the results are outside the measured range.

To be able to predict the consistency for the radioactive sludge slurry sample, from the data shown in Figure 7 , more data are required. More data are also required to investigate the differences for the results obtained from the Haake Rotovisco model RV20 (nonradioactive sample) and the RV30 system (radioactive sample) versus ThermoHaake RS150 RheoStress rheometer.

Table 9 - Summary of the Results Obtained from the Nonradioactive and Radioactive SRAT Product Samples for Sludge Batch 2

\begin{tabular}{|c|c|c|c|c|c|}
\hline Sample ID & $\begin{array}{c}\text { Total Solids } \\
(\text { wt.\%) }\end{array}$ & $\begin{array}{c}\text { Insoluble Solids } \\
\text { (wt.\%) }\end{array}$ & $\begin{array}{l}\begin{array}{l}\text { Yield Stress } \\
\left(\text { dynes } / \mathrm{cm}^{2}\right)\end{array} \\
\end{array}$ & $\begin{array}{l}\text { Consistency } \\
\text { (cp) }\end{array}$ & pH \\
\hline $\begin{array}{c}\text { 3B }^{12} \\
\text { (nonradioactive sample) }\end{array}$ & $16.5^{\mathrm{a}}$ & 11.7 & $55^{\mathrm{a}}$ & 8.3 & 6.50 \\
\hline $\begin{array}{c}\text { SB2-1 } \\
\text { (nonradioactive sample) }^{12}\end{array}$ & $16.4^{\mathrm{a}}$ & 11.2 & 35 & 9.4 & 6.81 \\
\hline $\begin{array}{c}\text { GFPS*-SRAT-174-2 } \\
\text { (nonradioactive sample) }\end{array}$ & $17.7^{\mathrm{a}}$ & 12.4 & $51^{\mathrm{a}}$ & 5.9 & 7.57 \\
\hline $\begin{array}{c}\text { GFPS*-SRAT-196-1 } \\
\text { (nonradioactive sample) }\end{array}$ & 18.2 & 13.0 & $61^{\mathrm{a}}$ & 5.0 & 7.55 \\
\hline $\begin{array}{c}\text { GFPS*-SRAT-174-3 } \\
\text { (nonradioactive sample) }\end{array}$ & 20.2 & 15.1 & $135^{\mathrm{a}}$ & 11.2 & 7.57 \\
\hline $\begin{array}{c}\text { Sludge Batch 2 SRAT } \\
\text { Product Sample (radioactive } \\
\text { sample) }\end{array}$ & 20.2 & 15.0 & 41 & $4.7^{\mathrm{a}}$ & 6.49 \\
\hline DWPF Operating Region ${ }^{11}$ & $18-25$ & N/A & $15-50$ & $5-12$ & N/A \\
\hline
\end{tabular}

* GFPS - Glass Feed Preparation System

${ }^{a}$ Data is outside of the DWPF Operating Region

As can be seen from Table 9, the nonradioactive samples meet the DWPF operating region for consistency. Four out of the five nonradioactive samples in Table 9 exceed the DWPF operating region for yield stress. The yield stress for the radioactive sample meets the criteria for the DWPF operating region, but the results for the consistency do not. To avoid making erroneous assumptions based on the data presented in Table 9; the flow curves for the SRAT product samples were plotted against the DWPF operating region for the SRAT product. The results for the radioactive sample can be found in Figure 3 and the nonradioactive data can be found in Appendix C, Figure C - 4. All of the SRAT products were within the DWPF operating region except for one; sample ID GFPS-SRAT-174-3. This entire flow curve was outside of the DWPF operating region.

The SRAT product rheology appears to be dependent upon many factors. The two factors that appear to affect the SRAT rheology, for the data set presented in Table 9, are insoluble solids content and the $\mathrm{pH}$ of the samples. As the $\mathrm{pH}$ is lowered for a sample having the same weight percent insoluble solids, it appears that the consistency and yield stress are lower. Upon plotting similar curves (as seen in Figure 6 and Figure 7) for the SRAT product samples in Table 9, no correlations between rheology and $\mathrm{pH}$ could be determined for these data sets. The reason 
for this is attributed to the ending $\mathrm{pH}$ values of the individual SRAT products. To be able to predict the behavior (i.e. consistency and yield stress) of the radioactive SRAT product from an insoluble solids and $\mathrm{pH}$ basis, more data will be required. The nonradioactive data for the SRAT product in Table 9 does not appear to provide any insight on the rheological behavior of the radioactive SRAT product. 
Table 10 - Summary of the Results Obtained from the Nonradioactive and Radioactive SME Product Samples for Sludge Batch 2

\begin{tabular}{|c|c|c|c|c|c|}
\hline Sample ID & $\begin{array}{c}\text { Total Solids } \\
\text { (wt.\%) }\end{array}$ & $\begin{array}{c}\text { Insoluble Solids } \\
\text { (wt.\%) }\end{array}$ & $\begin{array}{l}\text { Yield Stress } \\
\left(\text { dynes } / \mathrm{cm}^{2}\right)\end{array}$ & $\begin{array}{c}\text { Consistency } \\
\text { (cp) } \\
\end{array}$ & $\mathrm{pH}$ \\
\hline SME-1 $^{12}$ & 37.8 & 33.7 & 40 & 13 & 6.9 \\
\hline SME- $2^{12}$ & 41.0 & 36.4 & 70 & 18 & 6.8 \\
\hline SME-3 ${ }^{12}$ & 44.2 & 39.1 & 130 & 17 & 6.8 \\
\hline SME- $4^{12}$ & 48.9 & 42.8 & $260^{\mathrm{a}}$ & 34 & 7.0 \\
\hline SME-5 $^{12}$ & $51.7^{\mathrm{a}}$ & 45.3 & $400^{a}$ & $41^{\mathrm{a}}$ & 6.9 \\
\hline SME-6 $^{12}$ & $55.0^{a}$ & 48.2 & $600^{a}$ & $67^{a}$ & 7.0 \\
\hline $\begin{array}{c}\text { Sludge Batch } 2 \text { SME } \\
\text { Product Sample } \\
\text { (radioactive sample) }\end{array}$ & 45.3 & 40.8 & $200^{\mathrm{a}}$ & 9.5 & 6.29 \\
\hline $\begin{array}{c}\text { DWPF Operating } \\
\text { Region }^{11}\end{array}$ & $40-50$ & N/A & $25-150$ & $10-40$ & N/A \\
\hline
\end{tabular}

${ }^{a}$ Data is outside of the DWPF operating region

As seen in Table 10, there are cases in which the SME samples are not within the DWPF operating region for yield stress and consistency. The data for the radioactive sample were collected using the MVI rotor which has a different geometry then the MVII rotor (MVII has a larger gap size between the cup and rotor). The MVII rotor was used to collect all of the nonradioactive data reported in Table 10. Another conclusion that can be made from the data in Table 10, was that as the insoluble solids content was increased the yield stress and the consistency also increased while the $\mathrm{pH}$ remained constant for the nonradioactive samples. This is depicted graphically in Figures 8 and 9 below.

All of the data in Table 10 were compared to the DWPF operating region for the SME product. The radioactive data are plotted in Figure 4 and the nonradioactive data are plotted in Appendix C, Figure C - 5. The flow curves for Sample IDs SME-1 through SME-3 and the radioactive SME sample (see Figure 4) are within the DWPF operating region. The flow curves for Sample IDs SME-4 through SME-6 are outside of the DWPF operating region.

\section{Figure 8 - Yield Stress (Dynes $\left./ \mathrm{cm}^{2}\right)$ Dependence on Insoluble Weight Percent Solids for the SME Product Samples}

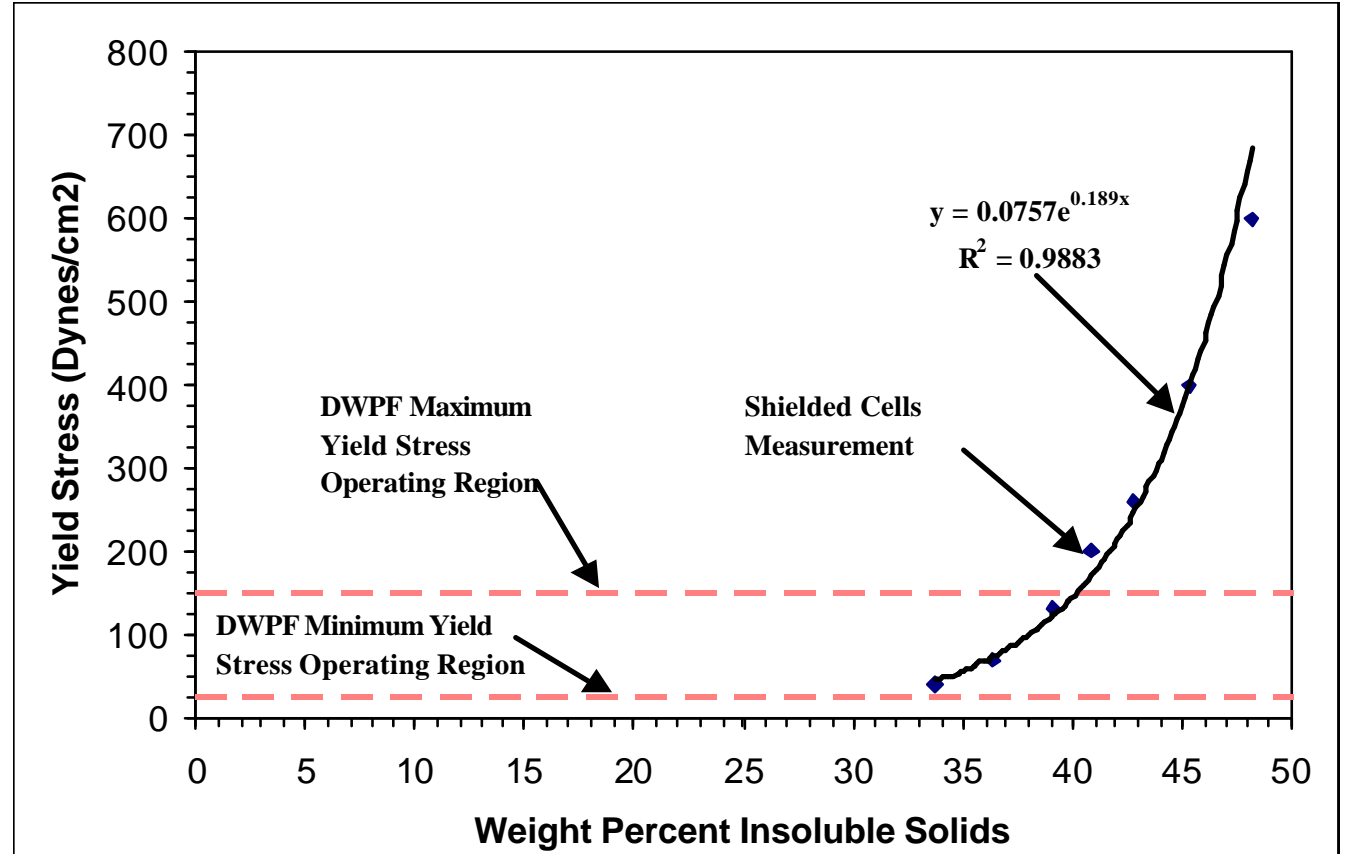


The curve fit of the data in Figure 8 provided an equation to predict yield stress based on insoluble solids content for the SME samples. Using this equation and the DWPF minimum and maximum values for yield stress, an insoluble solids loading for the SME samples were calculated at 30.7 and 40.2 weight percent, respectively. It also appears from the data in Figure 8, that a yield stress could be predicted for the radioactive sample. This should be used with caution, due to the different geometry used to obtain the measurements and the lack of radioactive measurements at different insoluble solids loading to verify the curve fit.

\section{Figure 9 - Consistency (Centipoise) Relationship to Insoluble Weight Percent Solids for the SME Product Samples}

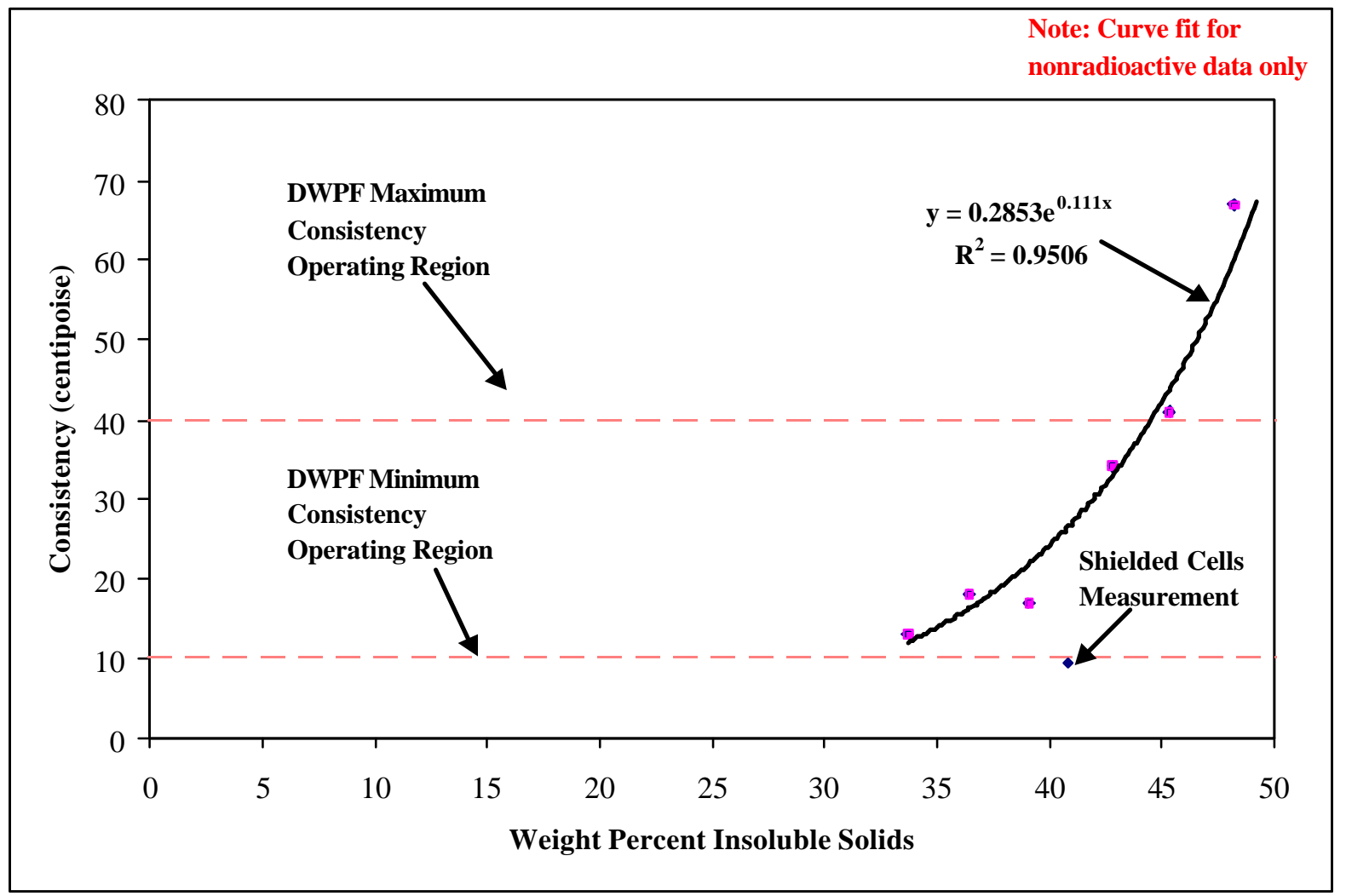

In Figure 9, the consistency data for the radioactive SME sample were outside of the data set collected for the nonradioactive samples, so it was not included in curve fit. The curve fit of the nonradioactive data provided an equation to predict consistency based on insoluble solids content for those SME samples. Using this equation and inputting the DWPF maximum and minimum values for consistency, yielded an insoluble solids loading of 32.0 and 44.5 weight percent, respectively. The nonradioactive data for the SME product does not appear to provide any insight on predicting the consistency for the radioactive SME product sample. This could be due to the different geometry used to obtain the data and the radioactive measurements at different insoluble solids loading, or it could be that the nonradioactive simulant was not very representative. 


\subsection{CONCLUSIONS}

1. From visual inspection of the samples, the sludge slurry and SME product samples appeared to entrain air readily whereas the SRAT product sample did not.

2. A DWPF operating region was created for each sample by using the Bingham Plastic model fit of the upper and lower ranges for consistency and yield stress for the sludge slurry, SRAT product, and SME product.

3. The radioactive sludge slurry sample exceeded the DWPF operating region from a shear rate range of 140 $\mathrm{s}^{-1}$ to $640 \mathrm{~s}^{-1}$. This data should be further evaluated to determine the impacts to the current DWPF system.

4. The flow curves for the radioactive SRAT product and SME product samples were within the DWPF operating region.

5. The rheological data (uncorrected), for the radioactive Sludge Batch 2 sludge slurry sample, are modeled using the Bingham Plastic model between the shear rates of $150 \mathrm{~s}^{-1}$ to $620 \mathrm{~s}^{-1}$. The results for the calculated yield stress and the consistency are $119 \mathrm{dynes} / \mathrm{cm}^{2}$ and 11.1 centipoise, respectively.

6. The rheological data (uncorrected), for the radioactive Sludge Batch 2 SRAT product sample was modeled using the Bingham Plastic model between the shear rates of $100 \mathrm{~s}^{-1}$ to $800 \mathrm{~s}^{-1}$. The results for the calculated yield stress and the consistency are 41 dynes $/ \mathrm{cm}^{2}$ and 4.67 centipoise, respectively.

7. The rheological data (uncorrected), for the radioactive Sludge Batch 2 SME product sample was modeled using the Bingham Plastic model between the shear rates of $150 \mathrm{~s}^{-1}$ to $1100 \mathrm{~s}^{-1}$. The results for the calculated yield stress and the consistency are 200 dynes $/ \mathrm{cm}^{2}$ and 9.5 centipoise, respectively.

8. The nonradioactive data collected using the Haake Rotovisco model RV20 or the ThermoHaake RS150 RheoStress rheometer could be curve fitted providing a yield stress and consistency dependency based on insoluble solids loading for those samples.

9. Nonradioactive simulants cannot be used to predict the behavior (yield stress and consistency) of radioactive samples for this report. More radioactive data are required at various weight percent insoluble solids and different $\mathrm{pHs}$ to confirm the results of the nonradioactive simulants.

10. There were differences in the data collected using the Haake Rotovisco model RV20 versus the ThermoHaake RS150 RheoStress rheometer for the nonradioactive samples. The reasons for these differences are unknown at this time, but should be investigated.

\subsection{QUALITY ASSURANCE}

All data and records generated from this task will be maintained in laboratory notebooks. Testing of the rheometer was completed under a TTR from DWPF ${ }^{1}$. 
Westinghouse Savannah River Company

Savannah River Technology Center
WSRC-TR-2002-00302

Page 26 of 64

\subsection{REFERENCES}

${ }^{1}$ M.A. Rios-Armstrong, Technical Task Request, HLW/DWPF/TTR-00-0016, Rev.1, September 7, 2000.

2 T.L. Fellinger, "Technical and QA Plan: Shielded Cells Confirmation Run Using Macro Batch 3 (Sludge Batch 2) Radioactive Sludge and Frit 200 (U)”WSRC-RP-2000-00698, Rev.0, November 3, 2000.

${ }^{3}$ Westinghouse Savannah River Company, "DWPF Waste Form Compliance Plan (U)", WSRC-IM-91-116-0, Rev.5, (11/95).

${ }^{4}$ Office of Environmental Restoration and Waste Management, "Waste Acceptance Product Specifications for Vitrified High-Level Waste Forms", USDOE Document DOE/EM-0093, Rev. 2, (12/96).

${ }^{5}$ T.L. Fellinger, N.E. Bibler, J.M. Pareizs, A.D. Cozzi, and C.L. Crawford, "Macrobatch 3 Acceptance Evaluation - Data from the Shielded Cells Demonstration of Defense Waste Processing Facility's Feed Preparation Cycles for Macrobatch 3 (Sludge Batch 2) (U), 'WSRC-RP-2001-00971, Rev. 0, November 1, 2001.

${ }^{6}$ T.L. Fellinger, N.E. Bibler, J.M. Pareizs, A.D. Cozzi and C.L. Crawford, "Macrobatch 3 Acceptance Evaluation - Data from the Shielded Cells Demonstration of Defense Waste Processing Facility's SME Feed Preparation Cycle for Macrobatch 3 (Sludge Batch 2) (U),” WSRC-RP-2001-01016, Rev. 0, November 19, 2001.

${ }^{7}$ T.L. Fellinger, N.E. Bibler, J.M. Pareizs, A.D. Cozzi, and C.L. Crawford, "Confirmation Run of the DWPF SRAT Cycle Using the Sludge-Only Flowsheet with Tank 40 Radioactive Sludge and Frit 200 in the Shielded Cells Facility (U),"WSRC-RP-2002-00076, Rev. 0, April 30, 2002.

${ }^{8}$ T.L. Fellinger, N.E. Bibler, J.M. Pareizs, A.D. Cozzi, and C.L. Crawford, "Confirmation Run of the DWPF SME Cycle and Results of the Glass Analysis Using the Sludge-Only Flowsheet with Tank 40 Radioactive Sludge and Frit 200 in the Shielded Cells Facility (U),” WSRC-RP-2002-00096, Rev. 0, June 26, 2002.

${ }^{9}$ M.S. Hay and N.E. Bibler, "Characterization and Decant of the Tank 42 Sludge Sample ESP-200 (U)", WSRCRP-98-00406, Rev.0, June 12, 1998.

${ }^{10}$ Haake, "Instruction Manual Rotovisco RV30".

11 “Technical Data Summary for the Defense Waste Processing Facility: Sludge Plant”, DPSTD-80-38-2.

${ }^{12}$ D.C. Koopman, "Sludge Batch 2 (MacroBatch3) Rheology Studies with Simulants (U)", WSRC-TR-2001-0051, Revision 0, February 23, 2001.

${ }^{13}$ B.A. Hamm, "High Level Caves Rheological Studies of Tanks 15H, 42H, and 8F Sludge/Slurries (U)", DPST84-439, April 11, 1984.

${ }^{14}$ J.C. Marek, "Preliminary Melter Feed Rheology Study (U)”, WSRC-RP-92-1240, October 21, 1992. 
Westinghouse Savannah River Company

WSRC-TR-2002-00302

Savannah River Technology Center

Page 27 of 64

\section{APPENDIX A - STANDARD OIL RESULTS (UP FLOW CURVES ONLY)}

Date :08-12-2002 Test date :02-08-2002

Substance :

Test number :

Operator :

Sensor : MV1 Meas. system : M5

$\%$ Tau $: 1 \% \quad \% \mathrm{D}: 100 \%$

Factor A : $3.220 \quad$ Factor M : 11.700 Gap : $0.000 \mathrm{~mm}$

Data stored in file C:IWINDOWS DESKTOP\DATAIS20812.ROT

\begin{tabular}{|c|c|c|c|}
\hline$\underline{\mathrm{D}[1 / \mathrm{s}]}$ & Tau (Pa) & $\underline{\mathrm{D}[1 / \mathrm{s}]}$ & Tau (Pa) \\
\hline 6.633 & 0.843 & 820.2 & 27.68 \\
\hline 25.24 & 1.728 & 842 & 28.46 \\
\hline 46.38 & 2.537 & 863.9 & 29.06 \\
\hline 68.26 & 3.326 & 885.6 & 29.83 \\
\hline 90.39 & 4.108 & 907.5 & 30.52 \\
\hline 113.2 & 4.952 & 930.6 & 31.32 \\
\hline 135.1 & 5.639 & 952.5 & 31.95 \\
\hline 157.1 & 6.258 & 974.2 & 32.79 \\
\hline 178.8 & 6.972 & 996.2 & 33.52 \\
\hline 200.7 & 7.769 & 1018 & 34.31 \\
\hline 224.4 & 8.367 & 1042 & 35.04 \\
\hline 246.1 & 9.275 & 1063 & 35.73 \\
\hline 267.8 & 9.91 & 1085 & 36.51 \\
\hline 289.5 & 10.67 & & \\
\hline 311.5 & 11.51 & & \\
\hline 333.4 & 12.02 & & \\
\hline 356.8 & 12.75 & & \\
\hline 378.8 & 13.52 & & \\
\hline 400.5 & 14.2 & & \\
\hline 422.4 & 15.02 & & \\
\hline 444.1 & 15.71 & & \\
\hline 465.9 & 16.36 & & \\
\hline 489.3 & 16.97 & & \\
\hline 511 & 17.69 & & \\
\hline 532.8 & 18.16 & & \\
\hline 554.5 & 19.47 & & \\
\hline 576.6 & 20.08 & & \\
\hline 599.9 & 20.73 & & \\
\hline 621.8 & 21.38 & & \\
\hline 643.5 & 21.84 & & \\
\hline 665.2 & 22.41 & & \\
\hline 687.2 & 23.12 & & \\
\hline 708.9 & 23.85 & & \\
\hline 732.5 & 24.8 & & \\
\hline 754.5 & 25.38 & & \\
\hline 774.9 & 26.19 & & \\
\hline 798.5 & 26.82 & & \\
\hline
\end{tabular}


Figure A - 1 - Flow Curve for Standard Oil at $23^{\circ} \mathrm{C}$

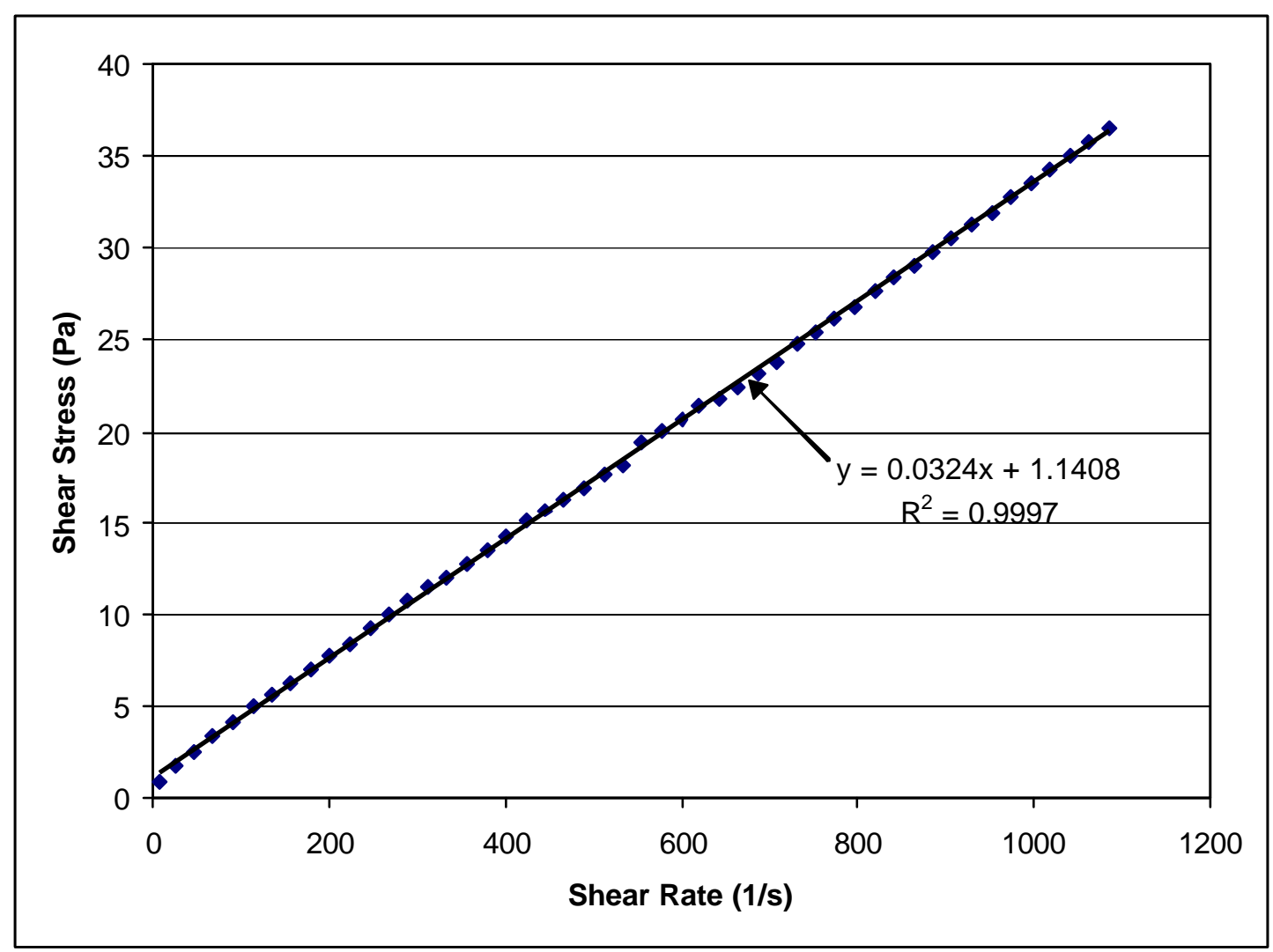

Known value for standard at $23^{\circ} \mathrm{C}: 32.63 \mathrm{cp}$ 
Westinghouse Savannah River Company

WSRC-TR-2002-00302

Savannah River Technology Center

Page 29 of 64

Date : 06-29-2002 Test date :05-07-2002

Substance :

Test number :

Operator :

Sensor : MV1 Meas. system : M5

$\%$ Tau : $1 \% \quad \% \mathrm{D}: 100 \%$

Factor A : $3.220 \quad$ Factor M : 11.700 Gap : $0.000 \mathrm{~mm}$

Data stored in file C:IWINDOWSIDESKTOPIDATAI56OL35T1.ROT

\begin{tabular}{|c|c|c|c|}
\hline$\underline{\mathrm{D}[1 / \mathrm{s}]}$ & Tau (Pa) & $\underline{\mathrm{D}[1 / \mathrm{s}]}$ & $\underline{\text { Tau }(\mathbf{P a})}$ \\
\hline 0 & 0.101 & 81.2 & 6.054 \\
\hline 0 & 0.198 & 82.92 & 6.164 \\
\hline 0.782 & 0.424 & 85.43 & 6.337 \\
\hline 2.135 & 0.641 & 87.13 & 6.384 \\
\hline 3.202 & 0.776 & 89.65 & 6.578 \\
\hline 5.07 & 0.964 & 92.18 & 6.736 \\
\hline 6.405 & 1.083 & 93.9 & 6.851 \\
\hline 8.635 & 1.256 & 96.47 & 6.961 \\
\hline 10.96 & 1.423 & 98.99 & 7.108 \\
\hline 12.47 & 1.522 & 100.7 & 7.229 \\
\hline 14.83 & 1.691 & 103.2 & 7.407 \\
\hline 17.27 & 1.859 & 104.9 & 7.565 \\
\hline 18.87 & 1.974 & 107.5 & 7.701 \\
\hline 21.37 & 2.158 & 110 & 7.869 \\
\hline 23.06 & 2.275 & 112.1 & 7.963 \\
\hline 25.5 & 2.416 & 113.8 & 8.084 \\
\hline 27.98 & 2.562 & 116.1 & 8.273 \\
\hline 29.85 & 2.684 & 117.8 & 8.394 \\
\hline 32.4 & 2.858 & 120.3 & 8.577 \\
\hline 34.12 & 2.979 & 122.9 & 8.756 \\
\hline 36.43 & 3.121 & 124.7 & 8.829 \\
\hline 38.98 & 3.274 & 127.1 & 9.007 \\
\hline 40.66 & 3.394 & 129.8 & 9.123 \\
\hline 43.23 & 3.573 & 131.5 & 9.27 \\
\hline 45.8 & 3.725 & 133.8 & 9.411 \\
\hline 47.46 & 3.835 & 135.5 & 9.495 \\
\hline 49.98 & 4.003 & 138 & 9.684 \\
\hline 51.66 & 4.123 & 140.7 & 9.894 \\
\hline 54.23 & 4.275 & 142.2 & 9.957 \\
\hline 56.8 & 4.438 & 144.7 & 10.08 \\
\hline 58.5 & 4.527 & 147.3 & 10.23 \\
\hline 60.96 & 4.685 & 149.1 & 10.4 \\
\hline 63.48 & 4.884 & 151.5 & 10.54 \\
\hline 65.17 & 4.968 & 153.3 & 10.65 \\
\hline 67.73 & 5.146 & 155.5 & 10.8 \\
\hline 69.4 & 5.272 & 158.2 & 10.91 \\
\hline 71.94 & 5.43 & 159.9 & 11.03 \\
\hline 74.45 & 5.587 & 162.4 & 11.13 \\
\hline 76.11 & 5.702 & 164.9 & 11.33 \\
\hline \multirow[t]{2}{*}{78.67} & 5.881 & 166.6 & 11.44 \\
\hline & & 169.1 & 11.6 \\
\hline
\end{tabular}


Westinghouse Savannah River Company

WSRC-TR-2002-00302

Savannah River Technology Center

Page 30 of 64

\begin{tabular}{|c|c|c|c|}
\hline$\underline{\mathrm{D}[1 / \mathrm{s}]}$ & Tau (Pa) & $\mathrm{D}[1 / \mathrm{s}]$ & Tau (Pa) \\
\hline 170.8 & 11.75 & 283.3 & 18.47 \\
\hline 173.3 & 11.88 & 285.9 & 18.5 \\
\hline 175.9 & 12.06 & 288.2 & 18.69 \\
\hline 177.5 & 12.17 & 289.9 & 18.81 \\
\hline 180.1 & 12.3 & 292.6 & 19.1 \\
\hline 182.4 & 12.47 & 295.1 & 19.26 \\
\hline 184.1 & 12.57 & 296.8 & 19.36 \\
\hline 186.6 & 12.75 & 299.3 & 19.53 \\
\hline 188.3 & 12.88 & 300.8 & 19.51 \\
\hline 191 & 13.02 & 303.5 & 19.69 \\
\hline 193.7 & 13.16 & 305.9 & 19.89 \\
\hline 195.2 & 13.19 & 307.7 & 19.97 \\
\hline 197.9 & 13.4 & 310.1 & 20.09 \\
\hline 199.6 & 13.49 & 312.8 & 20.13 \\
\hline 202.1 & 13.7 & 314.3 & 20.33 \\
\hline 204.7 & 13.91 & 316.8 & 20.48 \\
\hline 206.2 & 13.94 & 318.5 & 20.67 \\
\hline 208.9 & 14.06 & 321 & 20.81 \\
\hline 210.8 & 14.18 & 323.7 & 21.04 \\
\hline 213.5 & 14.27 & 325.4 & 21.12 \\
\hline 215 & 14.43 & 327.7 & 21.31 \\
\hline 217.9 & 14.56 & 330.5 & 21.43 \\
\hline 219.6 & 14.65 & 332.1 & 21.55 \\
\hline 221.9 & 14.86 & 334.5 & 21.65 \\
\hline 224.5 & 14.99 & 337 & 21.77 \\
\hline 226.1 & 15.1 & 338.7 & 21.85 \\
\hline 228.7 & 15.23 & 341.4 & 22.1 \\
\hline 230.5 & 15.32 & 343.1 & 22.19 \\
\hline 232.7 & 15.64 & 345.4 & 22.29 \\
\hline 235.4 & 15.73 & 347.9 & 22.45 \\
\hline 237.1 & 15.78 & 349.6 & 22.57 \\
\hline 239.6 & 15.91 & 352.3 & 22.69 \\
\hline 242.3 & 16.05 & 354.5 & 22.81 \\
\hline 243.8 & 16.18 & 356.5 & 22.97 \\
\hline 246.5 & 16.3 & 359.1 & 23.1 \\
\hline 248 & 16.33 & 360.6 & 23.22 \\
\hline 250.5 & 16.47 & 363.1 & 23.39 \\
\hline 253.1 & 16.62 & 365.6 & 23.61 \\
\hline 254.9 & 16.72 & 367.3 & 23.7 \\
\hline 257.3 & 16.81 & 369.8 & 23.98 \\
\hline 259.6 & 17.04 & 372.3 & 24.11 \\
\hline 261.3 & 17.12 & 374 & 24.17 \\
\hline 264 & 17.28 & 376.5 & 24.29 \\
\hline 265.7 & 17.37 & 378 & 24.49 \\
\hline 268.2 & 17.54 & 380.9 & 24.67 \\
\hline 270.7 & 17.72 & 383.1 & 24.8 \\
\hline 272.2 & 17.84 & 384.9 & 24.95 \\
\hline 274.9 & 17.95 & 387.5 & 25.07 \\
\hline 277.3 & 18.12 & 390 & 25.17 \\
\hline 279.1 & 18.24 & 391.7 & 25.26 \\
\hline 281.7 & 18.45 & 394 & 25.54 \\
\hline
\end{tabular}


Westinghouse Savannah River Company

Savannah River Technology Center
WSRC-TR-2002-00302

Page 31 of 64

\begin{tabular}{|c|c|c|c|}
\hline$\underline{D}[1 / \mathrm{s}]$ & Tau (Pa) & $\underline{\mathrm{D}[1 / \mathrm{s}]}$ & $\underline{\text { Tau }(\mathbf{P a})}$ \\
\hline 395.7 & 25.69 & 508.4 & 32.58 \\
\hline 399.1 & 25.9 & 510.9 & 32.74 \\
\hline 400.1 & 25.95 & 512.6 & 32.74 \\
\hline 402.6 & 26.18 & 515.2 & 32.84 \\
\hline 405.1 & 26.38 & 517.5 & 32.89 \\
\hline 407 & 26.52 & 519.2 & 33 \\
\hline 411.2 & 26.81 & 523.4 & 33.21 \\
\hline 413.6 & 26.93 & 526.1 & 33.36 \\
\hline 416.1 & 27.12 & 528.8 & 33.57 \\
\hline 417.6 & 27.13 & 530.3 & 33.68 \\
\hline 420.3 & 27.18 & 533 & 33.84 \\
\hline 428.9 & 27.56 & 541.2 & 34.31 \\
\hline 431.2 & 28 & 543.8 & 34.47 \\
\hline 433.7 & 28.17 & 546.1 & 34.62 \\
\hline 435.6 & 28.27 & 547.8 & 34.78 \\
\hline 438 & 28.42 & 550.3 & 35.15 \\
\hline 440.5 & 28.55 & 553 & 35.25 \\
\hline 442.2 & 28.62 & 554.7 & 35.31 \\
\hline 444.9 & 28.72 & 557.2 & 35.46 \\
\hline 446.6 & 28.73 & 558.7 & 35.41 \\
\hline 448.9 & 28.96 & 561.4 & 35.62 \\
\hline 466.6 & 30.11 & 579.1 & 36.67 \\
\hline 469.1 & 30.22 & 581.6 & 36.88 \\
\hline 471 & 30.3 & 583.1 & 36.98 \\
\hline 473.5 & 30.51 & 585.6 & 37.3 \\
\hline 475.6 & 30.69 & 588 & 37.4 \\
\hline 477.5 & 30.69 & 589.8 & 37.51 \\
\hline 479.8 & 30.74 & 592.4 & 37.46 \\
\hline 481.5 & 30.85 & 594.1 & 37.56 \\
\hline 484.2 & 31 & 596.4 & 37.77 \\
\hline 486.6 & 31.16 & 598.9 & 37.77 \\
\hline 488.4 & 31.27 & 600.4 & 37.88 \\
\hline 490.6 & 31.37 & 603.3 & 37.93 \\
\hline 493.5 & 31.53 & 605 & 38.09 \\
\hline 495 & 31.63 & 607.9 & 38.24 \\
\hline 497.5 & 31.79 & 609.6 & 38.4 \\
\hline 500 & 32.11 & 611.9 & 38.51 \\
\hline 501.7 & 32.21 & 614.2 & 38.77 \\
\hline 504.4 & 32.26 & 616.1 & 38.87 \\
\hline 505.9 & 32.42 & 618.7 & 39.03 \\
\hline
\end{tabular}


Westinghouse Savannah River Company

WSRC-TR-2002-00302

Savannah River Technology Center

Page 32 of 64

\begin{tabular}{|c|c|c|c|}
\hline$\underline{\mathrm{D}[1 / \mathrm{s}]}$ & Tau (Pa) & $\mathrm{D}[1 / \mathrm{s}]$ & Tau (Pa) \\
\hline 621.2 & 39.03 & 733.1 & 45.64 \\
\hline 622.7 & 39.19 & 735 & 45.69 \\
\hline 625.4 & 39.35 & 737.5 & 45.9 \\
\hline 627.1 & 39.45 & 740 & 46.16 \\
\hline 629.6 & 39.5 & 741.9 & 46.27 \\
\hline 632.1 & 39.76 & 744.4 & 46.43 \\
\hline 633.6 & 39.82 & 746.8 & 46.53 \\
\hline 636.3 & 39.97 & 748.5 & 46.58 \\
\hline 638.8 & 40.08 & 751 & 46.69 \\
\hline 640.5 & 40.24 & 752.7 & 46.74 \\
\hline 642.9 & 40.34 & 755.2 & 46.9 \\
\hline 644.7 & 40.5 & 757.7 & 47.11 \\
\hline 647.3 & 40.66 & 759.4 & 47.16 \\
\hline 649.6 & 40.76 & 761.9 & 47.21 \\
\hline 651.3 & 40.81 & 764.6 & 47.37 \\
\hline 653.8 & 40.97 & 766.1 & 47.53 \\
\hline 656.3 & 41.18 & 768.6 & 47.69 \\
\hline 658 & 41.29 & 770.3 & 47.84 \\
\hline 660.5 & 41.55 & 772.9 & 47.9 \\
\hline 662.2 & 41.55 & 775.4 & 48.16 \\
\hline 664.7 & 41.71 & 777.1 & 48.32 \\
\hline 667.3 & 41.81 & 779.6 & 48.47 \\
\hline 668.9 & 41.97 & 782.3 & 48.63 \\
\hline 671.3 & 42.07 & 783.8 & 48.63 \\
\hline 673.8 & 42.18 & 786.3 & 48.79 \\
\hline 675.5 & 42.34 & 788 & 48.79 \\
\hline 678.2 & 42.49 & 790.3 & 49.05 \\
\hline 680.5 & 42.65 & 793.2 & 49.21 \\
\hline 682.2 & 42.65 & 794.9 & 49.26 \\
\hline 684.9 & 42.81 & 797.2 & 49.42 \\
\hline 686.6 & 42.96 & 799.8 & 49.57 \\
\hline 689.1 & 43.12 & 801.3 & 49.68 \\
\hline 691.6 & 43.28 & 804 & 49.78 \\
\hline 693.3 & 43.44 & 805.7 & 49.89 \\
\hline 695.9 & 43.54 & 808 & 50.05 \\
\hline 696.5 & 43.59 & 810.7 & 50.2 \\
\hline 700.1 & 43.8 & 812.4 & 50.36 \\
\hline 701.8 & 43.91 & 814.9 & 50.52 \\
\hline 704.7 & 43.91 & 817.4 & 50.68 \\
\hline 706 & 44.07 & 818.9 & 50.68 \\
\hline 708.1 & 44.22 & 821.6 & 50.83 \\
\hline 711.8 & 44.49 & 823.3 & 50.99 \\
\hline 712.5 & 44.59 & 825.7 & 51.15 \\
\hline 715.6 & 44.75 & 828.2 & 51.31 \\
\hline 718 & 44.85 & 829.9 & 51.41 \\
\hline 719 & 44.96 & 832.6 & 51.57 \\
\hline 721.7 & 45.01 & 834.9 & 51.62 \\
\hline 723.6 & 45.17 & 836.6 & 51.73 \\
\hline 726.2 & 45.33 & 839.1 & 51.94 \\
\hline 729.1 & 45.27 & 840.6 & 52.09 \\
\hline 730.8 & 45.43 & 843.5 & 52.25 \\
\hline
\end{tabular}


Westinghouse Savannah River Company

WSRC-TR-2002-00302

Savannah River Technology Center

Page 33 of 64

\begin{tabular}{|c|c|c|c|}
\hline$\underline{\mathrm{D}[1 / \mathrm{s}]}$ & Tau (Pa) & $\underline{\mathrm{D}[1 / \mathrm{s}]}$ & Tau (Pa) \\
\hline 846 & 52.46 & 958.4 & 59.33 \\
\hline 847.7 & 52.57 & 960.1 & 59.49 \\
\hline 850.3 & 52.72 & 962.4 & 59.54 \\
\hline 852.1 & 52.77 & 964.3 & 59.7 \\
\hline 854.3 & 52.88 & 967 & 59.86 \\
\hline 857 & 53.04 & 969.5 & 59.96 \\
\hline 858.5 & 53.14 & 971 & 60.12 \\
\hline 861.2 & 53.25 & 973.7 & 60.28 \\
\hline 863.7 & 53.51 & 976.1 & 60.38 \\
\hline 865.2 & 53.51 & 977.9 & 60.43 \\
\hline 867.9 & 53.82 & 980.3 & 60.54 \\
\hline 869.6 & 53.82 & 981.9 & 60.59 \\
\hline 872.1 & 54.09 & 984.5 & 60.75 \\
\hline 874.5 & 54.14 & 987 & 60.85 \\
\hline 876.3 & 54.3 & 988.9 & 60.96 \\
\hline 878.7 & 54.51 & 991.6 & 61.12 \\
\hline 881.2 & 54.61 & 993.3 & 61.27 \\
\hline 882.9 & 54.72 & 995.2 & 61.38 \\
\hline 885.4 & 54.82 & 882.9 & 54.72 \\
\hline 887.1 & 54.98 & 885.4 & 54.82 \\
\hline 889.8 & 55.14 & 887.1 & 54.98 \\
\hline 892.1 & 55.35 & 889.8 & 55.14 \\
\hline 893.8 & 55.4 & 892.1 & 55.35 \\
\hline 896.5 & 55.56 & 893.8 & 55.4 \\
\hline 898.9 & 55.66 & 896.5 & 55.56 \\
\hline 900.7 & 55.77 & 898.9 & 55.66 \\
\hline 902.9 & 56.08 & 900.7 & 55.77 \\
\hline 904.9 & 56.18 & 902.9 & 56.08 \\
\hline 907.3 & 56.34 & 904.9 & 56.18 \\
\hline 909.8 & 56.39 & 907.3 & 56.34 \\
\hline 911.5 & 56.5 & 909.8 & 56.39 \\
\hline 913.8 & 56.66 & 911.5 & 56.5 \\
\hline 916.7 & 56.81 & 913.8 & 56.66 \\
\hline 918.4 & 56.97 & 916.7 & 56.81 \\
\hline 920.7 & 57.02 & 918.4 & 56.97 \\
\hline 922.4 & 57.13 & 920.7 & 57.02 \\
\hline 925.1 & 57.29 & 922.4 & 57.13 \\
\hline 927.5 & 57.55 & 925.1 & 57.29 \\
\hline 929.3 & 57.6 & 927.5 & 57.55 \\
\hline 931.5 & 57.76 & 929.3 & 57.6 \\
\hline 934.2 & 57.92 & 931.5 & 57.76 \\
\hline 935.9 & 58.07 & 934.2 & 57.92 \\
\hline 938.4 & 58.13 & 935.9 & 58.07 \\
\hline $\begin{array}{l}940.1 \\
\end{array}$ & 58.23 & $\begin{array}{l}938.4 \\
\end{array}$ & 58.13 \\
\hline 942.6 & 58.39 & 940.1 & 58.23 \\
\hline 945.3 & 58.55 & 942.6 & 58.39 \\
\hline 946.8 & 58.65 & 945.3 & 58.55 \\
\hline 949.3 & 58.76 & 946.8 & 58.65 \\
\hline 951.6 & 58.97 & 949.3 & 58.76 \\
\hline 953.5 & $\begin{array}{l}59.07 \\
\end{array}$ & 951.6 & 58.97 \\
\hline 956.1 & 59.17 & 953.5 & 59.07 \\
\hline
\end{tabular}


Westinghouse Savannah River Company

Savannah River Technology Center
WSRC-TR-2002-00302

Page 34 of 64

\begin{tabular}{|c|c|c|c|}
\hline$\underline{\mathrm{D}[1 / \mathrm{s}]}$ & Tau (Pa) & $\underline{\mathrm{D}[1 / \mathrm{s}]}$ & $\underline{\text { Tau }(\mathbf{P a})}$ \\
\hline 956.1 & 59.17 & 1068 & 65.42 \\
\hline 958.4 & 59.33 & 1070 & 65.42 \\
\hline 960.1 & 59.49 & 1073 & 65.63 \\
\hline 962.4 & 59.54 & 1075 & 65.73 \\
\hline 964.3 & 59.7 & 1077 & 65.84 \\
\hline 967 & 59.86 & 1079 & 65.94 \\
\hline 969.5 & 59.96 & 1082 & 66.15 \\
\hline 971 & 60.12 & 1084 & 66.26 \\
\hline 973.7 & 60.28 & 1086 & 66.41 \\
\hline 976.1 & 60.38 & 1089 & 66.52 \\
\hline 977.9 & 60.43 & 1090 & 66.68 \\
\hline 980.3 & 60.54 & 1093 & 66.78 \\
\hline 981.9 & 60.59 & & \\
\hline 984.5 & 60.75 & & \\
\hline 987 & 60.85 & & \\
\hline 988.9 & 60.96 & & \\
\hline 991.6 & 61.12 & & \\
\hline 9993.3 & 61.27 & & \\
\hline 995.2 & 61.38 & & \\
\hline $\begin{array}{l}997.9 \\
\end{array}$ & 61.54 & & \\
\hline 1000 & 61.69 & & \\
\hline 1002 & 61.8 & & \\
\hline 1004 & $\begin{array}{l}61.9 \\
\end{array}$ & & \\
\hline 1007 & 62.17 & & \\
\hline 1009 & 62.22 & & \\
\hline 1011 & 62.38 & & \\
\hline 1013 & 62.58 & & \\
\hline 1016 & 62.74 & & \\
\hline 1017 & 62.79 & & \\
\hline 1020 & 62.95 & & \\
\hline 1022 & 63 & & \\
\hline 1024 & 63.06 & & \\
\hline 1026 & 63.11 & & \\
\hline 1029 & 63.32 & & \\
\hline 1031 & 63.37 & & \\
\hline 1033 & 63.53 & & \\
\hline 1035 & 63.58 & & \\
\hline 1037 & 63.74 & & \\
\hline 1040 & 63.79 & & \\
\hline 1042 & 63.9 & & \\
\hline 1044 & 64.05 & & \\
\hline 1046 & 64.21 & & \\
\hline 1048 & 64.37 & & \\
\hline 1051 & 64.47 & & \\
\hline 1052 & 64.53 & & \\
\hline 1055 & 64.68 & & \\
\hline 1058 & 64.84 & & \\
\hline 1059 & 64.89 & & \\
\hline 1062 & 65.16 & & \\
\hline 1064 & 65.31 & & \\
\hline 1066 & 65.31 & & \\
\hline
\end{tabular}


Figure A - 2 - Flow Curve for Standard Oil at $25^{\circ} \mathrm{C}$

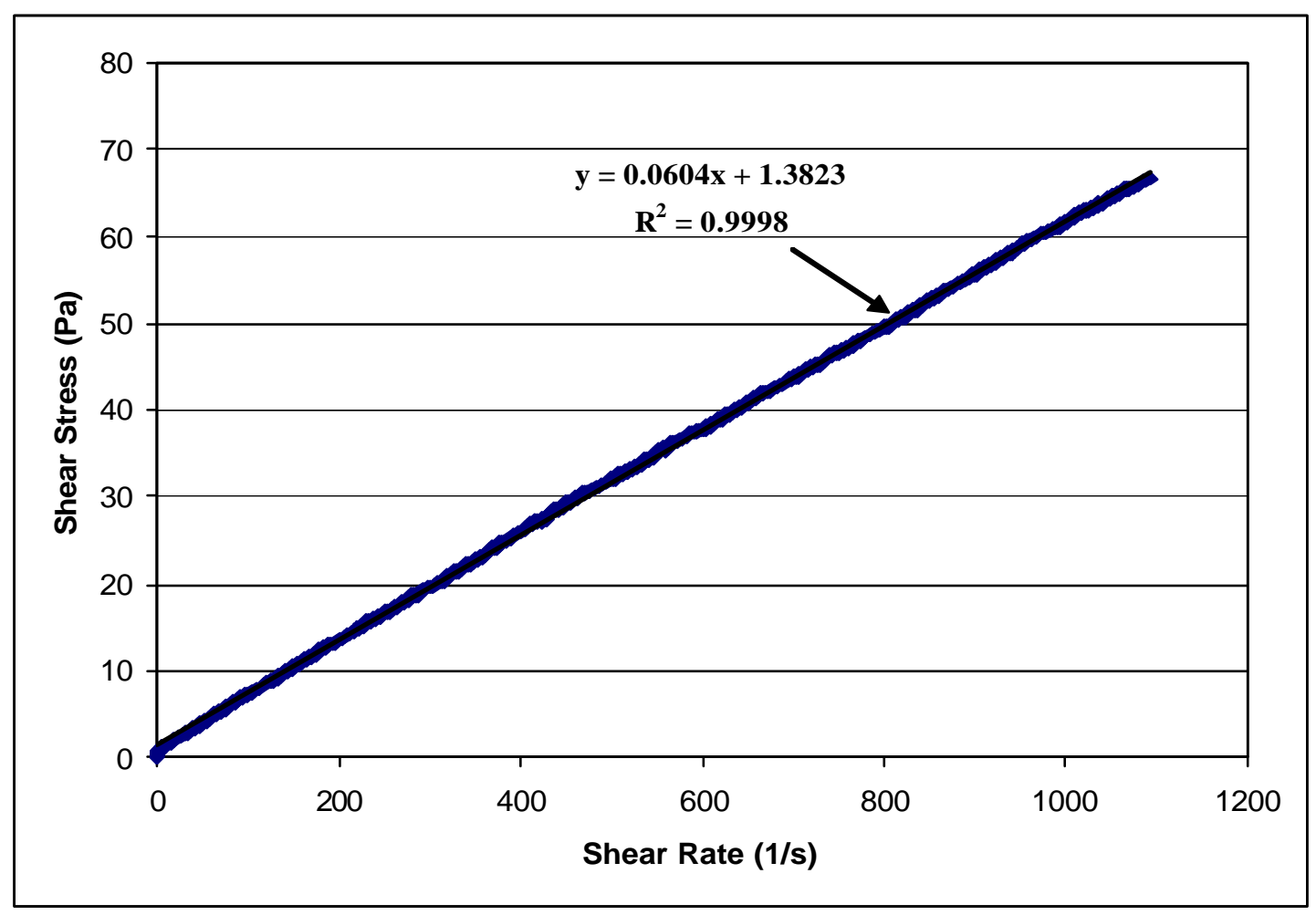

Known value for standard at $25^{\circ} \mathrm{C}: 55.7 \mathrm{cp}$ 


\section{APPENDIX B - RAW DATA FOR THE RADIOACTIVE SLUDE BATCH 2 SAMPLES (UP FLOW CURVES ONLY)}

Date :06-29-2002 Test date : 02-13-2002

Substance : Tank 40 Radioactive Sludge Slurry Sample @ 18.4 wt.\% total solids

Test number :

Operator :

Sensor : MV1 Meas. system : M5

$\%$ Tau $: 1 \% \quad \% \mathrm{D}: 100 \%$

Factor A : $3.220 \quad$ Factor M : 11.700 Gap : $0.000 \mathrm{~mm}$

Data stored in file C:IWINDOWSIDESKTOP\DATAITK40SL8.ROT

\begin{tabular}{|c|c|c|c|}
\hline$\underline{\mathrm{D}[1 / \mathrm{s}]}$ & $\underline{\text { Tau }(\mathbf{P a})}$ & $\underline{\mathrm{D}[1 / \mathrm{s}]}$ & $\underline{\operatorname{Tau}(\mathbf{P a})}$ \\
\hline 0 & 0.177 & 51.07 & 6.479 \\
\hline 0.019 & 0.209 & 52.88 & 6.599 \\
\hline 0.477 & 1.139 & 54.74 & 6.741 \\
\hline 0.877 & 1.582 & 55.64 & 6.804 \\
\hline 1.449 & 2.048 & 57.47 & 6.94 \\
\hline 3.279 & 2.732 & 59.34 & 7.145 \\
\hline 4.746 & 3.029 & 62.05 & 7.229 \\
\hline 6.195 & 3.326 & 63.91 & 7.381 \\
\hline 6.919 & 3.452 & 65.74 & 7.465 \\
\hline 8.54 & 3.651 & 67.57 & 7.68 \\
\hline 10.2 & 3.887 & 68.49 & 7.685 \\
\hline 16.43 & 4.349 & 74.97 & 8.095 \\
\hline 17.33 & 4.365 & 76.8 & 8.32 \\
\hline 19.14 & 4.454 & 78.63 & 8.504 \\
\hline 20.89 & 4.59 & 80.46 & 8.499 \\
\hline 22.72 & 4.674 & 81.37 & 8.509 \\
\hline 23.6 & 4.795 & 83.24 & 8.635 \\
\hline 25.41 & 4.889 & 85.05 & 8.735 \\
\hline 27.26 & 5.031 & 86.94 & 8.955 \\
\hline 29.07 & 5.115 & 87.84 & 9.007 \\
\hline 29.96 & 5.131 & 89.67 & 9.081 \\
\hline 42.77 & 5.938 & 102.6 & 9.784 \\
\hline 44.62 & 6.217 & 104.4 & 9.789 \\
\hline 46.49 & 6.332 & 106.3 & 9.962 \\
\hline 48.28 & 6.358 & 107.2 & 9.973 \\
\hline 49.22 & 6.384 & 109.1 & 10.07 \\
\hline
\end{tabular}


Westinghouse Savannah River Company

WSRC-TR-2002-00302

Savannah River Technology Center

Page 37 of 64

\begin{tabular}{|c|c|c|c|}
\hline$\underline{\mathrm{D}[1 / \mathrm{s}]}$ & $\underline{\text { Tau }(\mathbf{P a})}$ & $\underline{\mathrm{D}[1 / \mathrm{s}]}$ & $\underline{\text { Tau (Pa) }}$ \\
\hline 110.9 & 10.15 & 190.2 & 13.63 \\
\hline 112.1 & 10.27 & 192.1 & 13.7 \\
\hline 114 & 10.44 & 194 & 13.68 \\
\hline 114.8 & 10.47 & 195.8 & 13.67 \\
\hline 116.7 & 10.56 & 196.7 & 13.68 \\
\hline 118.8 & 10.77 & 198.6 & 13.69 \\
\hline 119.7 & 10.85 & 200.3 & 13.78 \\
\hline 121.4 & 10.85 & 202.2 & 13.76 \\
\hline 123.3 & 11 & 203.2 & 13.89 \\
\hline 125.2 & 11.21 & 204.9 & 13.9 \\
\hline 126 & 11.26 & 206.8 & 13.98 \\
\hline 128.1 & 11.27 & 208.7 & 13.98 \\
\hline 129.8 & 11.35 & 209.5 & 14.05 \\
\hline 131.5 & 11.46 & 211.4 & 14.11 \\
\hline 132.7 & 11.44 & 213.3 & 14.17 \\
\hline 132.7 & 11.44 & 215 & 14.21 \\
\hline 134.4 & 11.52 & 216 & 14.21 \\
\hline 136.1 & 11.59 & 217.9 & 14.3 \\
\hline 138 & 11.58 & 219.6 & 14.41 \\
\hline 139 & 11.62 & 221.3 & 14.34 \\
\hline 140.7 & 11.78 & 222.4 & 14.42 \\
\hline 142.6 & 11.82 & 224.2 & 14.38 \\
\hline 144.5 & 11.95 & 226.1 & 14.47 \\
\hline 145.2 & 12.02 & 227.8 & 14.43 \\
\hline 147.2 & 12.07 & 228.7 & 14.41 \\
\hline 149.1 & 12.15 & 230.6 & 14.55 \\
\hline 151 & 12.28 & 232.4 & 14.54 \\
\hline 151.7 & 12.29 & 234.3 & 14.58 \\
\hline 153.6 & 12.39 & 236.2 & 14.62 \\
\hline 155.5 & 12.58 & 237.1 & 14.63 \\
\hline 157.3 & 12.51 & 239 & 14.74 \\
\hline 158.2 & 12.54 & 240.7 & 14.64 \\
\hline 160.1 & 12.67 & 242.5 & 14.74 \\
\hline 161.8 & 12.81 & 243.4 & 14.7 \\
\hline 163.5 & 12.89 & 245.3 & 14.81 \\
\hline 164.5 & 12.89 & 247 & 14.79 \\
\hline 166.4 & 12.89 & 248.9 & 15.03 \\
\hline 168.1 & 13.12 & 249.9 & 14.97 \\
\hline 170.2 & 13.11 & 251.6 & 15.02 \\
\hline 171 & 13.05 & 253.3 & 15.02 \\
\hline 172.7 & 13.12 & 255.4 & 15.05 \\
\hline 174.6 & 13.18 & 256.2 & 15.09 \\
\hline 176.5 & 13.27 & 258.1 & 15.12 \\
\hline 177.3 & 13.24 & 260 & 15 \\
\hline 179.2 & 13.27 & 261.7 & 15.04 \\
\hline 181.1 & 13.35 & 262.5 & 15.06 \\
\hline 183 & 13.35 & 264.4 & 15.09 \\
\hline 183.8 & 13.41 & 266.3 & 15.05 \\
\hline 185.7 & 13.35 & 268.2 & 15.08 \\
\hline 187.6 & 13.45 & 269.1 & 15.04 \\
\hline 189.3 & 13.58 & 270.9 & 15.04 \\
\hline
\end{tabular}


Westinghouse Savannah River Company

WSRC-TR-2002-00302

Savannah River Technology Center

Page 38 of 64

\begin{tabular}{|c|c|c|c|}
\hline $\mathrm{D}[1 / \mathrm{s}]$ & Tau (Pa) & $\underline{\mathrm{D}[1 / \mathrm{s}]}$ & Tau (Pa) \\
\hline 272.8 & 14.99 & 354.2 & 16.29 \\
\hline 274.5 & 15.03 & 356.1 & 16.29 \\
\hline 275.4 & 15.1 & 357.8 & 16.39 \\
\hline 277.3 & 15.18 & 358.9 & 16.41 \\
\hline 279.1 & 15.21 & 360.6 & 16.28 \\
\hline 281 & 15.3 & 362.6 & 16.27 \\
\hline 281.9 & 15.32 & 364.3 & 16.39 \\
\hline 283.6 & 15.37 & 365.2 & 16.38 \\
\hline 285.5 & 15.27 & 367.1 & 16.33 \\
\hline 287.3 & 15.28 & 368.8 & 16.44 \\
\hline 288.2 & 15.31 & 370.7 & 16.44 \\
\hline 290.1 & 15.34 & 371.5 & 16.43 \\
\hline 291.8 & 15.2 & 373.4 & 16.47 \\
\hline 293.7 & 15.48 & 375.1 & 16.6 \\
\hline 294.7 & 15.45 & 377 & 16.64 \\
\hline 296.6 & 15.51 & 378 & 16.57 \\
\hline 298.5 & 15.5 & 379.7 & 16.68 \\
\hline 300.2 & 15.55 & 381.4 & 16.62 \\
\hline 301 & 15.62 & 383.5 & 16.73 \\
\hline 303.1 & 15.65 & 384.3 & 16.71 \\
\hline 304.8 & 15.65 & 386.2 & 16.73 \\
\hline 306.5 & 15.68 & 388.1 & 16.74 \\
\hline 307.5 & 15.71 & 389.8 & 16.73 \\
\hline 309.4 & 15.63 & 390.8 & 16.61 \\
\hline 311.1 & 15.79 & 392.7 & 16.66 \\
\hline 313 & 15.87 & 394.6 & 16.77 \\
\hline 313.9 & 15.86 & 396.3 & 16.58 \\
\hline 315.7 & 15.89 & 397.2 & 16.61 \\
\hline 317.6 & 15.91 & 399.1 & 16.65 \\
\hline 319.3 & 15.93 & 400.9 & 16.62 \\
\hline 320.2 & 15.94 & 402.6 & 16.67 \\
\hline 322.1 & 15.85 & 403.7 & 16.69 \\
\hline 323.9 & 15.89 & 405.4 & 16.68 \\
\hline 325.8 & 15.85 & 407.2 & 16.62 \\
\hline 326.7 & 15.88 & 409.1 & 16.8 \\
\hline 328.4 & 15.96 & 410 & 16.86 \\
\hline 330.3 & 16 & 411.7 & 16.93 \\
\hline 332.2 & 16.02 & 413.6 & 17.02 \\
\hline 333.2 & 16.07 & 415.5 & 16.98 \\
\hline 335.1 & 16.15 & 416.3 & 16.95 \\
\hline 336.8 & 16.11 & 418.2 & 17.19 \\
\hline 338.5 & 16.18 & 420.1 & 17.14 \\
\hline 339.7 & 16.25 & 422 & 17.19 \\
\hline 341.4 & 16.19 & 423.2 & 17.06 \\
\hline 343.1 & 16.16 & 424.9 & 16.96 \\
\hline 345 & 16.03 & 427 & 16.94 \\
\hline 346 & 16.03 & 427.9 & 16.8 \\
\hline 347.7 & 16.17 & 429.8 & 16.76 \\
\hline 349.6 & 16.21 & 431 & 16.78 \\
\hline 351.3 & 16.22 & 432.9 & 16.93 \\
\hline 352.3 & 16.24 & 434.6 & 16.99 \\
\hline
\end{tabular}


Westinghouse Savannah River Company

WSRC-TR-2002-00302

Savannah River Technology Center

Page 39 of 64

\begin{tabular}{|c|c|c|c|}
\hline $\mathrm{D}[\mathbf{1} / \mathrm{s}]$ & Tau (Pa) & $\mathrm{D}[\mathbf{1} / \mathrm{s}]$ & Tau (Pa) \\
\hline 436.3 & 16.95 & 518.1 & 17.71 \\
\hline 437.5 & 16.99 & 519.8 & 17.75 \\
\hline 439.2 & 16.97 & 520.6 & 17.79 \\
\hline 441.1 & 16.98 & 522.7 & 17.8 \\
\hline 442.8 & 16.95 & 524.4 & 17.86 \\
\hline 443.8 & 17 & 526.1 & 17.88 \\
\hline 445.7 & 17.05 & 527.1 & 17.86 \\
\hline 447.4 & 17.09 & 529 & 17.85 \\
\hline 449.3 & 17.22 & 530.7 & 17.79 \\
\hline 450.2 & 17.22 & 532.6 & 17.67 \\
\hline 452 & 17.19 & 533.5 & 17.67 \\
\hline 453.9 & 17.12 & 535.4 & 17.69 \\
\hline 455.8 & 17.03 & 537 & 17.69 \\
\hline 456.5 & 17.09 & 539.1 & 17.76 \\
\hline 458.4 & 17.15 & 539.8 & 17.74 \\
\hline 460.3 & 17.37 & 541.7 & 17.79 \\
\hline 462.1 & 17.36 & 543.6 & 17.81 \\
\hline 463 & 17.36 & 545.4 & 17.91 \\
\hline 464.9 & 17.39 & 546.1 & 17.89 \\
\hline 466.6 & 17.54 & 548 & 17.87 \\
\hline 468.3 & 17.49 & 550.1 & 17.87 \\
\hline 469.5 & 17.48 & 551.8 & 17.83 \\
\hline 471.2 & 17.25 & 552.8 & 17.81 \\
\hline 473.1 & 17.12 & 554.7 & 17.89 \\
\hline 474.8 & 17.29 & 556.4 & 18.01 \\
\hline 475.8 & 17.29 & 558.3 & 17.98 \\
\hline 477.7 & 17.71 & 559.3 & 17.91 \\
\hline 479.6 & 17.53 & 561 & 17.84 \\
\hline 481.5 & 17.64 & 562.9 & 17.86 \\
\hline 482.1 & 17.58 & 564.8 & 17.83 \\
\hline 484 & 17.47 & 565.6 & 17.83 \\
\hline 485.9 & 17.51 & 567.5 & 17.87 \\
\hline 487.8 & 17.51 & 569.2 & 17.93 \\
\hline 488.5 & 17.49 & 571.3 & 17.91 \\
\hline 490.6 & 17.41 & 572 & 17.92 \\
\hline 492.4 & 17.45 & 573.9 & 17.87 \\
\hline 494.1 & 17.42 & 575.9 & 17.84 \\
\hline 495.2 & 17.35 & 577.6 & 17.82 \\
\hline 496.9 & 17.49 & 578.5 & 17.85 \\
\hline 498.7 & 17.5 & 580.4 & 17.93 \\
\hline 500.6 & 17.48 & 582.1 & 18.03 \\
\hline 501.5 & 17.46 & 583.9 & 17.96 \\
\hline 503.2 & 17.46 & 585 & 17.99 \\
\hline 505.1 & 17.43 & 586.7 & 18.01 \\
\hline 506.8 & 17.46 & 588.4 & 18.07 \\
\hline 507.8 & 17.47 & 590.1 & 18.27 \\
\hline 509.7 & 17.54 & 591.1 & 18.25 \\
\hline 511.4 & 17.57 & 593 & 18.17 \\
\hline 513.3 & 17.57 & 594.9 & 18.16 \\
\hline 514.3 & 17.58 & 596.6 & 18.14 \\
\hline 516.2 & 17.57 & 598.3 & 18.01 \\
\hline
\end{tabular}


Westinghouse Savannah River Company

WSRC-TR-2002-00302

Savannah River Technology Center

Page 40 of 64

\begin{tabular}{|c|c|c|c|}
\hline $\mathrm{D}[1 / \mathrm{s}]$ & Tau (Pa) & $\underline{\mathrm{D}[1 / \mathrm{s}]}$ & Tau (Pa) \\
\hline 601.2 & 18.05 & 682.8 & 17.98 \\
\hline 603.1 & 18.04 & 684.5 & 17.93 \\
\hline 605 & 18.19 & 686.2 & 17.89 \\
\hline 605.8 & 18.13 & 688.1 & 17.9 \\
\hline 607.7 & 18.17 & 689.1 & 17.9 \\
\hline 609.4 & 17.63 & 690.8 & 17.93 \\
\hline 611.3 & 17.76 & 692.5 & 17.96 \\
\hline 612.3 & 17.77 & 694.6 & 17.97 \\
\hline 614 & 17.82 & 695.4 & 17.97 \\
\hline 615.9 & 17.87 & 697.3 & 18 \\
\hline 617.6 & 17.89 & 699.2 & 17.99 \\
\hline 618.7 & 18.04 & 700.9 & 18 \\
\hline 620.5 & 18.43 & 701.8 & 17.99 \\
\hline 622.2 & 18.4 & 703.8 & 17.96 \\
\hline 624.3 & 18.22 & 705.7 & 17.98 \\
\hline 625 & 18.15 & 707.4 & 17.99 \\
\hline 626.9 & 18.04 & 708.3 & 17.99 \\
\hline 628.7 & 17.98 & 710 & 17.97 \\
\hline 630.6 & 17.94 & 712 & 18.16 \\
\hline 631.5 & 17.94 & 713.7 & 18.13 \\
\hline 633.2 & 17.9 & 714.6 & 18.15 \\
\hline 634.9 & 17.86 & 716.5 & 18.11 \\
\hline 636.8 & 17.83 & 718.2 & 18.09 \\
\hline 638 & 17.8 & 720.1 & 18.1 \\
\hline 639.7 & 17.73 & 721.1 & 18.11 \\
\hline 641.4 & 17.76 & 722.8 & 18.07 \\
\hline 643.3 & 17.77 & 724.7 & 18.37 \\
\hline 644.3 & 17.76 & 726.6 & 18.43 \\
\hline 646 & 17.73 & 727.4 & 18.39 \\
\hline 647.9 & 17.73 & 729.3 & 18.35 \\
\hline 649.6 & 17.72 & 731.2 & 18.31 \\
\hline 650.8 & 17.77 & 732.9 & 18.26 \\
\hline 652.5 & 17.76 & 733.9 & 18.27 \\
\hline 654.2 & 17.82 & 735.8 & 18.24 \\
\hline 656.1 & 17.84 & 737.5 & 18.26 \\
\hline 657.1 & 17.82 & 739.4 & 18.3 \\
\hline 658.8 & 17.81 & 740.4 & 18.29 \\
\hline 660.7 & 17.8 & 742.3 & 18.26 \\
\hline 662.4 & 17.87 & 744 & 18.26 \\
\hline 663.3 & 17.83 & 745.7 & 18.29 \\
\hline 665.2 & 17.86 & 746.8 & 18.28 \\
\hline 667 & 17.85 & 748.5 & 18.29 \\
\hline 668.9 & 17.85 & 750.3 & 18.29 \\
\hline 669.6 & 17.86 & 752.4 & 18.28 \\
\hline 671.5 & 17.89 & 753.1 & 18.28 \\
\hline 673.4 & 17.85 & 754.8 & 18.29 \\
\hline 675.4 & 17.96 & 756.7 & 18.27 \\
\hline 676.3 & 17.96 & 758.7 & 18.29 \\
\hline 678 & 17.93 & 759.4 & 18.29 \\
\hline 679.9 & 17.92 & 761.3 & 18.33 \\
\hline 681.6 & 17.92 & 763 & 18.32 \\
\hline
\end{tabular}


Westinghouse Savannah River Company

WSRC-TR-2002-00302

Savannah River Technology Center

Page 41 of 64

\begin{tabular}{|c|c|l|l|}
\hline$\underline{\mathbf{D}}[\mathbf{1} / \mathbf{s}]$ & $\underline{\text { Tau }} \mathbf{( P a )}$ & $\underline{\mathbf{D}}[\mathbf{1} / \mathbf{s}]$ & $\underline{\text { Tau }} \mathbf{( P a )}$ \\
\hline 765.1 & 18.33 & & \\
\hline 765.9 & 18.36 & & \\
\hline 767.8 & 18.36 & & \\
\hline 769.7 & 18.31 & & \\
\hline 771.4 & 18.29 & & \\
\hline 772.2 & 18.29 & & \\
\hline 774.3 & 18.32 & & \\
\hline 776 & 18.38 & & \\
\hline 777.9 & 18.39 & & \\
\hline 778.9 & 18.42 & & \\
\hline 780.6 & 18.42 & & \\
\hline 782.3 & 18.41 & & \\
\hline 784.4 & 18.44 & & \\
\hline 785.1 & 18.46 & & \\
\hline 787.1 & 18.47 & & \\
\hline 789 & 18.42 & & \\
\hline 790.7 & 18.42 & & \\
\hline 791.6 & 18.44 & & \\
\hline & & & \\
\hline
\end{tabular}

Date :06-29-2002 Test date :02-19-2002

Substance : Tank 40 Radioactive SRAT Product @ 20.2 wt.\% total solids

Test number :

Operator :

Sensor : MV1 Meas. system : M5

$\%$ Tau $: 1 \% \quad \% \mathrm{D} \quad: 100 \%$

Factor A : $3.220 \quad$ Factor M : 11.700 Gap : $0.000 \mathrm{~mm}$

Data stored in file C:IWINDOWSIDESKTOPIDATAITK40SR1.ROT

\begin{tabular}{|c|c|c|c|}
\hline$\underline{\mathbf{D}} \mathbf{1} \mathbf{1} \mathbf{s}]$ & $\underline{\text { Tau }} \mathbf{( P a )}$ & $\underline{\mathbf{D}}[\mathbf{1} / \mathbf{s}]$ & $\underline{\text { Tau }}$ (Pa) \\
\hline 0 & 0.37 & 24.27 & 3.226 \\
\hline 0.076 & 0.465 & 25.18 & 3.247 \\
\hline 0.343 & 0.672 & 27.03 & 3.289 \\
\hline 0.763 & 0.917 & 28.82 & 3.321 \\
\hline 1.696 & 1.377 & 30.65 & 3.363 \\
\hline 2.211 & 1.556 & 31.59 & 3.394 \\
\hline 3.431 & 1.872 & 33.4 & 3.426 \\
\hline 4.784 & 2.116 & 35.23 & 3.462 \\
\hline 6.214 & 2.306 & 37.06 & 3.483 \\
\hline 6.977 & 2.389 & 37.93 & 3.499 \\
\hline 8.54 & 2.553 & 39.8 & 3.525 \\
\hline 10.37 & 2.685 & 41.65 & 3.573 \\
\hline 11.21 & 2.752 & 43.48 & 3.594 \\
\hline 12.94 & 2.843 & 44.41 & 3.62 \\
\hline 14.7 & 2.938 & 46.24 & 3.651 \\
\hline 16.45 & 3.014 & 48.07 & 3.672 \\
\hline 17.35 & 3.051 & 49.92 & 3.683 \\
\hline 18.91 & 3.09 & 50.82 & 3.698 \\
\hline 20.66 & 3.137 & 52.65 & 3.719 \\
\hline 22.47 & 3.184 & 54.48 & 3.735 \\
\hline
\end{tabular}


Westinghouse Savannah River Company

WSRC-TR-2002-00302

Savannah River Technology Center

Page 42 of 64

\begin{tabular}{|c|c|c|c|}
\hline$\underline{\mathrm{D}[1 / \mathrm{s}]}$ & Tau (Pa) & $\underline{\mathrm{D}[1 / \mathrm{s}]}$ & Tau (Pa) \\
\hline 56.31 & 3.772 & 136.9 & 4.517 \\
\hline 57.26 & 3.814 & 138.8 & 4.533 \\
\hline 59.09 & 3.84 & 140.7 & 4.538 \\
\hline 60.92 & 3.866 & 142.6 & 4.533 \\
\hline 62.77 & 3.893 & 143.5 & 4.517 \\
\hline 63.68 & 3.908 & 145.4 & 4.601 \\
\hline 65.51 & 3.924 & 147.3 & 4.58 \\
\hline 67.36 & 3.919 & 149.3 & 4.585 \\
\hline 69.17 & 3.919 & 150 & 4.59 \\
\hline 70.11 & 3.94 & 152.1 & 4.548 \\
\hline 71.98 & 3.966 & 153.8 & 4.585 \\
\hline 73.81 & 3.982 & 155.5 & 4.59 \\
\hline 75.64 & 4.013 & 156.5 & 4.58 \\
\hline 76.59 & 4.024 & 158.4 & 4.632 \\
\hline 78.4 & 4.024 & 160.1 & 4.632 \\
\hline 80.25 & 4.06 & 162 & 4.669 \\
\hline 82.1 & 4.102 & 163 & 4.679 \\
\hline 83.03 & 4.102 & 164.7 & 4.695 \\
\hline 84.86 & 4.144 & 166.6 & 4.711 \\
\hline 86.67 & 4.134 & 168.5 & 4.8 \\
\hline 88.52 & 4.176 & 169.3 & 4.868 \\
\hline 89.46 & 4.16 & 171.2 & 4.79 \\
\hline 91.32 & 4.171 & 172.9 & 4.779 \\
\hline 93.13 & 4.192 & 174.8 & 4.8 \\
\hline 95 & 4.202 & 175.7 & 4.805 \\
\hline 95.92 & 4.234 & 177.5 & 4.832 \\
\hline 97.8 & 4.223 & 179.6 & 4.8 \\
\hline 99.65 & 4.249 & 181.3 & 4.874 \\
\hline 101.5 & 4.26 & 183 & 4.91 \\
\hline 102.5 & 4.255 & 184.1 & 4.868 \\
\hline 104.3 & 4.27 & 185.9 & 4.884 \\
\hline 106.1 & 4.286 & 187.8 & 4.926 \\
\hline 108.7 & 4.354 & 189.5 & 5.01 \\
\hline 109.7 & 4.354 & 190.4 & 5.01 \\
\hline 110.7 & 4.349 & 192.1 & 4.973 \\
\hline 114.9 & 4.307 & 194 & 4.921 \\
\hline 115.5 & 4.365 & 196 & 4.942 \\
\hline 116.7 & 4.359 & 196.9 & 4.9 \\
\hline 120.7 & 4.349 & 198.8 & 4.91 \\
\hline 121.4 & 4.391 & 200.7 & 4.889 \\
\hline 122.6 & 4.422 & 202.4 & 4.874 \\
\hline 123.7 & 4.449 & 203.4 & 4.889 \\
\hline 127.5 & 4.464 & 205.1 & 4.874 \\
\hline 128.7 & 4.475 & 207 & 4.984 \\
\hline 129.8 & 4.48 & 208.7 & 4.968 \\
\hline 130.8 & 4.506 & 209.7 & 4.994 \\
\hline 131.9 & 4.517 & 211.6 & 4.984 \\
\hline 132.9 & 4.527 & 213.3 & 5.094 \\
\hline 133.8 & 4.517 & 215.2 & 5.12 \\
\hline 135 & 4.496 & 216.2 & 5.162 \\
\hline 135.9 & 4.522 & 217.9 & 5.141 \\
\hline
\end{tabular}


Westinghouse Savannah River Company

Savannah River Technology Center
WSRC-TR-2002-00302

Page 43 of 64

\begin{tabular}{|c|c|c|c|}
\hline$\underline{D}[1 / \mathrm{s}]$ & Tau (Pa) & $\underline{\mathrm{D}[1 / \mathrm{s}]}$ & $\underline{\text { Tau }(\mathbf{P a})}$ \\
\hline 219.6 & 5.136 & 301.4 & 5.561 \\
\hline 221.5 & 5.099 & 303.1 & 5.587 \\
\hline 222.4 & 5.052 & 305 & 5.556 \\
\hline 224.4 & 5.094 & 305.9 & 5.577 \\
\hline 226.3 & 5.152 & 307.7 & 5.55 \\
\hline 228 & 5.125 & 309.6 & 5.545 \\
\hline 230.8 & 5.157 & 312.2 & 5.587 \\
\hline 232.6 & 5.104 & 314.1 & 5.655 \\
\hline 234.5 & 5.162 & 315.9 & 5.697 \\
\hline 235.4 & 5.12 & 317 & 5.687 \\
\hline 237.1 & 5.125 & 318.7 & 5.629 \\
\hline 243.6 & 5.262 & 325.2 & 5.76 \\
\hline 245.3 & 5.272 & 327.1 & 5.781 \\
\hline 247 & 5.288 & 328.8 & 5.75 \\
\hline 248.2 & 5.277 & 329.8 & 5.75 \\
\hline 249.9 & 5.272 & 331.7 & 5.739 \\
\hline 251.6 & 5.309 & 333.4 & 5.781 \\
\hline 253.5 & 5.304 & 334.5 & 5.765 \\
\hline 254.5 & 5.272 & 336.2 & 5.855 \\
\hline 256.2 & 5.272 & 338.5 & 5.886 \\
\hline 258.3 & 5.304 & 339.5 & 5.839 \\
\hline 271.1 & 5.43 & 352.6 & 5.975 \\
\hline 272.8 & 5.398 & 354.5 & 5.834 \\
\hline 273.7 & 5.388 & 356.3 & 5.844 \\
\hline 275.6 & 5.382 & 357.2 & 5.813 \\
\hline 277.3 & 5.466 & 358.9 & 5.86 \\
\hline 279.3 & 5.419 & 360.8 & 6.017 \\
\hline 280.2 & 5.388 & 362.6 & 6.012 \\
\hline 282.1 & 5.372 & 363.5 & 6.012 \\
\hline 283.8 & 5.367 & 365.4 & 6.017 \\
\hline 285.7 & 5.424 & 367.1 & 5.986 \\
\hline 286.5 & 5.43 & 369 & 6.033 \\
\hline 288.4 & 5.414 & 370 & 6.028 \\
\hline 290.3 & 5.419 & 371.7 & 6.017 \\
\hline 292.2 & 5.43 & 373.6 & 6.08 \\
\hline 293 & 5.445 & 375.3 & 5.996 \\
\hline 294.9 & 5.54 & 376.3 & 5.991 \\
\hline 296.8 & 5.592 & 378.2 & 6.028 \\
\hline 298.5 & 5.603 & 379.9 & 5.938 \\
\hline 299.6 & 5.629 & 381.8 & 5.907 \\
\hline
\end{tabular}


Westinghouse Savannah River Company

WSRC-TR-2002-00302

Savannah River Technology Center

Page 44 of 64

\begin{tabular}{|c|c|c|c|}
\hline$\underline{\mathrm{D}[1 / \mathrm{s}]}$ & Tau (Pa) & $\mathrm{D}[1 / \mathrm{s}]$ & Tau (Pa) \\
\hline 382.8 & 5.959 & 465.1 & 6.416 \\
\hline 384.7 & 6.064 & 466.1 & 6.4 \\
\hline 386.6 & 6.022 & 468 & 6.369 \\
\hline 388.3 & 6.017 & 469.9 & 6.411 \\
\hline 389 & 6.022 & 471.6 & 6.479 \\
\hline 391 & 6.017 & 472.3 & 6.489 \\
\hline 392.9 & 6.064 & 474.3 & 6.458 \\
\hline 394.6 & 6.127 & 476.2 & 6.489 \\
\hline 395.7 & 6.112 & 478.1 & 6.531 \\
\hline 397.4 & 6.101 & 478.8 & 6.652 \\
\hline 399.1 & 6.091 & 480.7 & 6.647 \\
\hline 401.1 & 6.101 & 482.6 & 6.594 \\
\hline 402 & 6.112 & 484.5 & 6.547 \\
\hline 403.7 & 6.117 & 486.3 & 6.558 \\
\hline 405.8 & 6.18 & 487.2 & 6.547 \\
\hline 407.7 & 6.164 & 488.9 & 6.5 \\
\hline 408.3 & 6.143 & 490.6 & 6.5 \\
\hline 410.2 & 6.175 & 492.6 & 6.39 \\
\hline 412.1 & 6.196 & 493.5 & 6.39 \\
\hline 413.8 & 6.264 & 495.4 & 6.442 \\
\hline 414.8 & 6.253 & 497.1 & 6.51 \\
\hline 416.7 & 6.248 & 499 & 6.552 \\
\hline 418.6 & 6.279 & 500 & 6.526 \\
\hline 420.3 & 6.243 & 501.9 & 6.573 \\
\hline 421.3 & 6.243 & 503.8 & 6.573 \\
\hline 423.2 & 6.253 & 505.5 & 6.5 \\
\hline 424.9 & 6.196 & 506.5 & 6.578 \\
\hline 426.6 & 6.211 & 508.4 & 6.61 \\
\hline 427.7 & 6.185 & 510.1 & 6.62 \\
\hline 429.5 & 6.19 & 512 & 6.615 \\
\hline 431.4 & 6.18 & 512.8 & 6.594 \\
\hline 433.3 & 6.363 & 514.7 & 6.715 \\
\hline 434 & 6.327 & 516.6 & 6.71 \\
\hline 435.7 & 6.274 & 518.5 & 6.678 \\
\hline 437.7 & 6.253 & 519.2 & 6.662 \\
\hline 439.6 & 6.211 & 521.1 & 6.668 \\
\hline 440.3 & 6.227 & 522.9 & 6.683 \\
\hline 442.2 & 6.258 & 524.8 & 6.678 \\
\hline 444.1 & 6.19 & 525.5 & 6.694 \\
\hline 446 & 6.248 & 527.6 & 6.736 \\
\hline 446.8 & 6.19 & 529.3 & 6.762 \\
\hline 448.7 & 6.154 & 531.1 & 6.825 \\
\hline 450.6 & 6.232 & 532 & 6.841 \\
\hline 452.3 & 6.274 & 533.9 & 6.83 \\
\hline 453.3 & 6.3 & 535.8 & 6.815 \\
\hline 455.2 & 6.505 & 537.5 & 6.872 \\
\hline 456.9 & 6.474 & 538.5 & 6.836 \\
\hline 458.6 & 6.458 & 540.4 & 6.862 \\
\hline 459.8 & 6.463 & 542.1 & 6.888 \\
\hline 461.5 & 6.447 & 543.8 & 6.746 \\
\hline 463.2 & 6.432 & 545 & 6.741 \\
\hline
\end{tabular}


Westinghouse Savannah River Company

WSRC-TR-2002-00302

Savannah River Technology Center

Page 45 of 64

\begin{tabular}{|c|c|c|c|}
\hline$\underline{\mathrm{D}[1 / \mathrm{s}]}$ & Tau (Pa) & $\underline{\mathrm{D}[1 / \mathrm{s}]}$ & Tau (Pa) \\
\hline 546.7 & 6.731 & 628.1 & 7.066 \\
\hline 548.6 & 6.752 & 630 & 6.961 \\
\hline 550.5 & 6.757 & 631.7 & 6.956 \\
\hline 551.3 & 6.746 & 633.6 & 6.961 \\
\hline 553.4 & 6.794 & 634.6 & 6.956 \\
\hline 554.9 & 6.804 & 636.5 & 6.94 \\
\hline 556.8 & 6.841 & 638.2 & 6.956 \\
\hline 557.7 & 6.841 & 639.9 & 6.904 \\
\hline 559.6 & 6.752 & 641 & 6.893 \\
\hline 561.6 & 6.83 & 642.8 & 6.909 \\
\hline 563.3 & 6.872 & 644.5 & 6.925 \\
\hline 564 & 6.867 & 646.4 & 6.946 \\
\hline 565.9 & 6.904 & 647.3 & 6.951 \\
\hline 567.8 & 6.883 & 649 & 7.014 \\
\hline 569.8 & 6.888 & 651 & 7.035 \\
\hline 570.7 & 6.893 & 652.7 & 7.061 \\
\hline 572.4 & 6.919 & 653.6 & 7.03 \\
\hline 574.1 & 6.893 & 655.3 & 7.056 \\
\hline 576 & 6.893 & 657.4 & 7.035 \\
\hline 577 & 6.925 & 659.1 & 7.056 \\
\hline 578.7 & 6.919 & 659.9 & 7.045 \\
\hline 580.6 & 6.919 & 661.8 & 7.061 \\
\hline 582.3 & 6.904 & 663.7 & 7.014 \\
\hline 583.3 & 6.836 & 665.6 & 7.003 \\
\hline 585.2 & 6.878 & 666.4 & 7.014 \\
\hline 586.9 & 6.883 & 668.3 & 7.03 \\
\hline 588.6 & 6.904 & 670.2 & 7.098 \\
\hline 589.6 & 6.94 & 671.9 & 7.119 \\
\hline 591.5 & 6.946 & 672.9 & 7.119 \\
\hline 593.2 & 6.967 & 674.8 & 7.192 \\
\hline 595.1 & 6.998 & 676.5 & 7.177 \\
\hline 596.1 & 7.009 & 678.2 & 7.161 \\
\hline 598 & 7.024 & 679.4 & 7.177 \\
\hline 599.9 & 7.056 & 681.1 & 7.166 \\
\hline 601.6 & 7.04 & 683 & 7.166 \\
\hline 602.5 & 7.056 & 684.9 & 7.177 \\
\hline 604.3 & 7.103 & 685.6 & 7.177 \\
\hline 606.2 & 7.124 & 687.6 & 7.156 \\
\hline 607.9 & 7.129 & 689.5 & 7.129 \\
\hline 608.8 & 7.093 & 691.2 & 7.135 \\
\hline 610.7 & 7.203 & 691.9 & 7.166 \\
\hline 612.4 & 7.203 & 693.8 & 7.166 \\
\hline 614.4 & 7.213 & 695.6 & 7.198 \\
\hline 615.3 & 7.208 & 697.7 & 7.234 \\
\hline 617 & 7.213 & 698.4 & 7.213 \\
\hline 618.7 & 7.208 & 700.3 & 7.239 \\
\hline 620.8 & 7.344 & 702 & 7.234 \\
\hline 621.6 & 7.287 & 703.9 & 7.219 \\
\hline 623.5 & 7.224 & 704.9 & 7.219 \\
\hline 625.4 & 7.135 & 706.8 & 7.213 \\
\hline 627.1 & 7.114 & 708.5 & 7.219 \\
\hline
\end{tabular}


Westinghouse Savannah River Company

WSRC-TR-2002-00302

Savannah River Technology Center

Page 46 of 64

\begin{tabular}{|c|c|c|c|}
\hline$\underline{\mathrm{D}[1 / \mathrm{s}]}$ & $\underline{\text { Tau }(\mathbf{P a})}$ & $\underline{\mathrm{D}[1 / \mathrm{s}]}$ & $\underline{\operatorname{Tau}(\mathbf{P a})}$ \\
\hline 710.2 & 7.234 & 751.6 & 7.413 \\
\hline 711.4 & 7.281 & 753.5 & 7.449 \\
\hline 713.1 & 7.245 & 755.4 & 7.465 \\
\hline 714.8 & 7.26 & 756.4 & 7.455 \\
\hline 716.7 & 7.271 & 758.1 & 7.46 \\
\hline 717.7 & 7.271 & 760.2 & 7.449 \\
\hline 719.4 & 7.302 & 761.1 & 7.449 \\
\hline 721.3 & 7.318 & 763 & 7.476 \\
\hline 723.4 & 7.329 & 764.8 & 7.465 \\
\hline 724.1 & 7.365 & 766.7 & 7.465 \\
\hline 726.1 & 7.26 & 767.8 & 7.465 \\
\hline 728 & 7.302 & 769.7 & 7.57 \\
\hline 729.7 & 7.334 & 771.4 & 7.591 \\
\hline 730.6 & 7.339 & 772.4 & 7.559 \\
\hline 732.5 & 7.323 & 774.3 & 7.559 \\
\hline 734.3 & 7.339 & 776.2 & 7.57 \\
\hline 736.2 & 7.381 & 777.9 & 7.58 \\
\hline 737.1 & 7.371 & 778.9 & 7.539 \\
\hline 738.8 & 7.407 & 780.6 & 7.533 \\
\hline 740.7 & 7.434 & 782.3 & 7.575 \\
\hline 742.4 & 7.428 & 784.2 & 7.586 \\
\hline 743.4 & 7.423 & 785.1 & 7.507 \\
\hline 745.3 & 7.413 & 787.1 & 7.497 \\
\hline 747 & 7.428 & 789 & 7.528 \\
\hline 749.1 & 7.413 & 790.9 & 7.544 \\
\hline 749.7 & 7.413 & 791.6 & 7.565 \\
\hline
\end{tabular}

Date : 06-12-2002 Test date :05-20-2002

Substance : Tank 40 Radioactive SME Product @ 45 wt.\% Total Solids

Test number :

Operator :

Sensor : MV1 Meas. system : M5

\%Tau : $1 \% \quad \% \mathrm{D}: 100 \%$

Factor A : $3.220 \quad$ Factor M : 11.700 Gap : $0.000 \mathrm{~mm}$

Data stored in file C:IDATAITK40SM1.ROT

\begin{tabular}{|c|c|c|c|}
\hline$\underline{\mathbf{D}}[\mathbf{1} / \mathbf{s}]$ & $\underline{\mathbf{T a u}(\mathbf{P a})}$ & $\underline{\mathbf{D}[\mathbf{1} / \mathbf{s}]}$ & $\underline{\mathbf{T a u}(\mathbf{P a})}$ \\
\hline $0.00 \mathrm{E}+00$ & $1.60 \mathrm{E}-01$ & $2.68 \mathrm{E}+01$ & $1.46 \mathrm{E}+01$ \\
\hline $2.67 \mathrm{E}-01$ & $7.44 \mathrm{E}-01$ & $2.88 \mathrm{E}+01$ & $1.48 \mathrm{E}+01$ \\
\hline $5.72 \mathrm{E}-01$ & $1.31 \mathrm{E}+00$ & $3.08 \mathrm{E}+01$ & $1.50 \mathrm{E}+01$ \\
\hline $2.36 \mathrm{E}+00$ & $3.99 \mathrm{E}+00$ & $3.28 \mathrm{E}+01$ & $1.52 \mathrm{E}+01$ \\
\hline $2.97 \mathrm{E}+00$ & $4.72 \mathrm{E}+00$ & $3.48 \mathrm{E}+01$ & $1.53 \mathrm{E}+01$ \\
\hline $3.72 \mathrm{E}+00$ & $5.39 \mathrm{E}+00$ & $3.68 \mathrm{E}+01$ & $1.55 \mathrm{E}+01$ \\
\hline $6.06 \mathrm{E}+00$ & $7.25 \mathrm{E}+00$ & $3.99 \mathrm{E}+01$ & $1.57 \mathrm{E}+01$ \\
\hline $7.78 \mathrm{E}+00$ & $8.45 \mathrm{E}+00$ & $4.19 \mathrm{E}+01$ & $1.58 \mathrm{E}+01$ \\
\hline $9.53 \mathrm{E}+00$ & $9.58 \mathrm{E}+00$ & $4.39 \mathrm{E}+01$ & $1.59 \mathrm{E}+01$ \\
\hline $1.13 \mathrm{E}+01$ & $1.07 \mathrm{E}+01$ & $4.59 \mathrm{E}+01$ & $1.61 \mathrm{E}+01$ \\
\hline $1.31 \mathrm{E}+01$ & $1.15 \mathrm{E}+01$ & $4.79 \mathrm{E}+01$ & $1.62 \mathrm{E}+01$ \\
\hline $1.60 \mathrm{E}+01$ & $1.25 \mathrm{E}+01$ & $5.10 \mathrm{E}+01$ & $1.63 \mathrm{E}+01$ \\
\hline $1.80 \mathrm{E}+01$ & $1.30 \mathrm{E}+01$ & $5.30 \mathrm{E}+01$ & $1.64 \mathrm{E}+01$ \\
\hline $1.99 \mathrm{E}+01$ & $1.35 \mathrm{E}+01$ & $5.50 \mathrm{E}+01$ & $1.65 \mathrm{E}+01$ \\
\hline $2.19 \mathrm{E}+01$ & $1.39 \mathrm{E}+01$ & $5.70 \mathrm{E}+01$ & $1.66 \mathrm{E}+01$ \\
\hline
\end{tabular}


Westinghouse Savannah River Company

WSRC-TR-2002-00302

Savannah River Technology Center

Page 47 of 64

\begin{tabular}{l|l}
$2.39 \mathrm{E}+01$ & $1.42 \mathrm{E}+01$
\end{tabular}

$5.90 \mathrm{E}+01$

$1.67 \mathrm{E}+01$ 
Westinghouse Savannah River Company

WSRC-TR-2002-00302

Savannah River Technology Center

Page 48 of 64

\begin{tabular}{|c|c|c|c|}
\hline$\underline{\mathrm{D}[1 / \mathrm{s}]}$ & Tau (Pa) & $\mathrm{D}[1 / \mathrm{s}]$ & $\underline{\text { Tau }(\mathbf{P a})}$ \\
\hline $6.21 \mathrm{E}+01$ & $1.69 \mathrm{E}+01$ & $1.78 \mathrm{E}+02$ & $2.05 \mathrm{E}+01$ \\
\hline $6.41 \mathrm{E}+01$ & $1.69 \mathrm{E}+01$ & $1.79 \mathrm{E}+02$ & $2.05 \mathrm{E}+01$ \\
\hline $6.61 \mathrm{E}+01$ & $1.70 \mathrm{E}+01$ & $1.80 \mathrm{E}+02$ & $2.06 \mathrm{E}+01$ \\
\hline $6.81 \mathrm{E}+01$ & $1.71 \mathrm{E}+01$ & $1.84 \mathrm{E}+02$ & $2.06 \mathrm{E}+01$ \\
\hline $7.02 \mathrm{E}+01$ & $1.71 \mathrm{E}+01$ & $1.86 \mathrm{E}+02$ & $2.06 \mathrm{E}+01$ \\
\hline $7.22 \mathrm{E}+01$ & $1.72 \mathrm{E}+01$ & $1.87 \mathrm{E}+02$ & $2.06 \mathrm{E}+01$ \\
\hline $7.52 \mathrm{E}+01$ & $1.73 \mathrm{E}+01$ & $1.89 \mathrm{E}+02$ & $2.06 \mathrm{E}+01$ \\
\hline $7.73 \mathrm{E}+01$ & $1.74 \mathrm{E}+01$ & $1.91 \mathrm{E}+02$ & $2.07 \mathrm{E}+01$ \\
\hline $7.93 \mathrm{E}+01$ & $1.75 \mathrm{E}+01$ & $1.93 \mathrm{E}+02$ & $2.07 \mathrm{E}+01$ \\
\hline $8.13 \mathrm{E}+01$ & $1.76 \mathrm{E}+01$ & $1.95 \mathrm{E}+02$ & $2.08 \mathrm{E}+01$ \\
\hline $8.33 \mathrm{E}+01$ & $1.77 \mathrm{E}+01$ & $1.98 \mathrm{E}+02$ & $2.09 \mathrm{E}+01$ \\
\hline $8.64 \mathrm{E}+01$ & $1.78 \mathrm{E}+01$ & $2.01 \mathrm{E}+02$ & $2.10 \mathrm{E}+01$ \\
\hline $8.84 \mathrm{E}+01$ & $1.79 \mathrm{E}+01$ & $2.03 \mathrm{E}+02$ & $2.10 \mathrm{E}+01$ \\
\hline $9.04 \mathrm{E}+01$ & $1.80 \mathrm{E}+01$ & $2.05 \mathrm{E}+02$ & $2.11 \mathrm{E}+01$ \\
\hline $9.24 \mathrm{E}+01$ & $1.80 \mathrm{E}+01$ & $2.07 \mathrm{E}+02$ & $2.12 \mathrm{E}+01$ \\
\hline $9.45 \mathrm{E}+01$ & $1.81 \mathrm{E}+01$ & $2.10 \mathrm{E}+02$ & $2.13 \mathrm{E}+01$ \\
\hline $9.75 \mathrm{E}+01$ & $1.83 \mathrm{E}+01$ & $2.12 \mathrm{E}+02$ & $2.14 \mathrm{E}+01$ \\
\hline $9.96 \mathrm{E}+01$ & $1.83 \mathrm{E}+01$ & $2.14 \mathrm{E}+02$ & $2.14 \mathrm{E}+01$ \\
\hline $1.02 \mathrm{E}+02$ & $1.84 \mathrm{E}+01$ & $2.16 \mathrm{E}+02$ & $2.13 \mathrm{E}+01$ \\
\hline $1.04 \mathrm{E}+02$ & $1.84 \mathrm{E}+01$ & $2.18 \mathrm{E}+02$ & $2.13 \mathrm{E}+01$ \\
\hline $1.06 \mathrm{E}+02$ & $1.84 \mathrm{E}+01$ & $2.21 \mathrm{E}+02$ & $2.14 \mathrm{E}+01$ \\
\hline $1.09 \mathrm{E}+02$ & $1.85 \mathrm{E}+01$ & $2.23 \mathrm{E}+02$ & $2.15 \mathrm{E}+01$ \\
\hline $1.11 \mathrm{E}+02$ & $1.85 \mathrm{E}+01$ & $2.25 \mathrm{E}+02$ & $2.15 \mathrm{E}+01$ \\
\hline $1.12 \mathrm{E}+02$ & $1.86 \mathrm{E}+01$ & $2.27 \mathrm{E}+02$ & $2.15 \mathrm{E}+01$ \\
\hline $1.14 \mathrm{E}+02$ & $1.87 \mathrm{E}+01$ & $2.29 \mathrm{E}+02$ & $2.17 \mathrm{E}+01$ \\
\hline $1.16 \mathrm{E}+02$ & $1.88 \mathrm{E}+01$ & $2.32 \mathrm{E}+02$ & $2.16 \mathrm{E}+01$ \\
\hline $1.19 \mathrm{E}+02$ & $1.89 \mathrm{E}+01$ & $2.34 \mathrm{E}+02$ & $2.18 \mathrm{E}+01$ \\
\hline $1.21 \mathrm{E}+02$ & $1.90 \mathrm{E}+01$ & $2.36 \mathrm{E}+02$ & $2.17 \mathrm{E}+01$ \\
\hline $1.24 \mathrm{E}+02$ & $1.90 \mathrm{E}+01$ & $2.38 \mathrm{E}+02$ & $2.18 \mathrm{E}+01$ \\
\hline $1.25 \mathrm{E}+02$ & $1.91 \mathrm{E}+01$ & $2.40 \mathrm{E}+02$ & $2.18 \mathrm{E}+01$ \\
\hline $1.28 \mathrm{E}+02$ & $1.92 \mathrm{E}+01$ & $2.42 \mathrm{E}+02$ & $2.17 \mathrm{E}+01$ \\
\hline $1.30 \mathrm{E}+02$ & $1.93 \mathrm{E}+01$ & $2.45 \mathrm{E}+02$ & $2.17 \mathrm{E}+01$ \\
\hline $1.33 \mathrm{E}+02$ & $1.92 \mathrm{E}+01$ & $2.47 \mathrm{E}+02$ & $2.18 \mathrm{E}+01$ \\
\hline $1.34 \mathrm{E}+02$ & $1.93 \mathrm{E}+01$ & $2.49 \mathrm{E}+02$ & $2.18 \mathrm{E}+01$ \\
\hline $1.37 \mathrm{E}+02$ & $1.93 \mathrm{E}+01$ & $2.51 \mathrm{E}+02$ & $2.19 \mathrm{E}+01$ \\
\hline $1.38 \mathrm{E}+02$ & $1.94 \mathrm{E}+01$ & $2.53 \mathrm{E}+02$ & $2.20 \mathrm{E}+01$ \\
\hline $1.41 \mathrm{E}+02$ & $1.95 \mathrm{E}+01$ & $2.56 \mathrm{E}+02$ & $2.21 \mathrm{E}+01$ \\
\hline $1.44 \mathrm{E}+02$ & $1.96 \mathrm{E}+01$ & $2.58 \mathrm{E}+02$ & $2.21 \mathrm{E}+01$ \\
\hline $1.45 \mathrm{E}+02$ & $1.96 \mathrm{E}+01$ & $2.60 \mathrm{E}+02$ & $2.21 \mathrm{E}+01$ \\
\hline $1.48 \mathrm{E}+02$ & $1.97 \mathrm{E}+01$ & $2.62 \mathrm{E}+02$ & $2.22 \mathrm{E}+01$ \\
\hline $1.50 \mathrm{E}+02$ & $1.98 \mathrm{E}+01$ & $2.64 \mathrm{E}+02$ & $2.24 \mathrm{E}+01$ \\
\hline $1.53 \mathrm{E}+02$ & $1.98 \mathrm{E}+01$ & $2.67 \mathrm{E}+02$ & $2.23 \mathrm{E}+01$ \\
\hline $1.55 \mathrm{E}+02$ & $1.99 \mathrm{E}+01$ & $2.69 \mathrm{E}+02$ & $2.22 \mathrm{E}+01$ \\
\hline $1.57 \mathrm{E}+02$ & $2.00 \mathrm{E}+01$ & $2.71 \mathrm{E}+02$ & $2.23 \mathrm{E}+01$ \\
\hline $1.59 \mathrm{E}+02$ & $2.00 \mathrm{E}+01$ & $2.73 \mathrm{E}+02$ & $2.24 \mathrm{E}+01$ \\
\hline $1.63 \mathrm{E}+02$ & $2.01 \mathrm{E}+01$ & $2.75 \mathrm{E}+02$ & $2.25 \mathrm{E}+01$ \\
\hline $1.64 \mathrm{E}+02$ & $2.01 \mathrm{E}+01$ & $2.77 \mathrm{E}+02$ & $2.25 \mathrm{E}+01$ \\
\hline $1.65 \mathrm{E}+02$ & $2.02 \mathrm{E}+01$ & $2.80 \mathrm{E}+02$ & $2.25 \mathrm{E}+01$ \\
\hline $1.67 \mathrm{E}+02$ & $2.02 \mathrm{E}+01$ & $2.83 \mathrm{E}+02$ & $2.25 \mathrm{E}+01$ \\
\hline $1.70 \mathrm{E}+02$ & $2.03 \mathrm{E}+01$ & $2.84 \mathrm{E}+02$ & $2.26 \mathrm{E}+01$ \\
\hline
\end{tabular}


Westinghouse Savannah River Company

WSRC-TR-2002-00302

Savannah River Technology Center

Page 49 of 64

\begin{tabular}{|c|c|c|c|}
\hline $1.71 \mathrm{E}+02$ & $2.04 \mathrm{E}+01$ & $2.86 \mathrm{E}+02$ & $2.26 \mathrm{E}+01$ \\
\hline $1.77 \mathrm{E}+02$ & $2.05 \mathrm{E}+01$ & $2.88 \mathrm{E}+02$ & $2.29 \mathrm{E}+01$ \\
\hline$\underline{\mathrm{D}[1 / \mathrm{s}]}$ & $\underline{\text { Tau }}(\mathbf{P a})$ & $\mathrm{D}[1 / \mathrm{s}]$ & $\underline{\text { Tau }(\mathbf{P a})}$ \\
\hline $2.92 \mathrm{E}+02$ & $2.29 \mathrm{E}+01$ & $4.06 \mathrm{E}+02$ & $2.42 \mathrm{E}+01$ \\
\hline $2.93 \mathrm{E}+02$ & $2.28 \mathrm{E}+01$ & $4.08 \mathrm{E}+02$ & $2.44 \mathrm{E}+01$ \\
\hline $2.96 \mathrm{E}+02$ & $2.28 \mathrm{E}+01$ & $4.10 \mathrm{E}+02$ & $2.43 \mathrm{E}+01$ \\
\hline $2.98 \mathrm{E}+02$ & $2.29 \mathrm{E}+01$ & $4.12 \mathrm{E}+02$ & $2.44 \mathrm{E}+01$ \\
\hline $3.00 \mathrm{E}+02$ & $2.29 \mathrm{E}+01$ & $4.15 \mathrm{E}+02$ & $2.45 \mathrm{E}+01$ \\
\hline $3.03 \mathrm{E}+02$ & $2.29 \mathrm{E}+01$ & $4.17 \mathrm{E}+02$ & $2.45 \mathrm{E}+01$ \\
\hline $3.04 \mathrm{E}+02$ & $2.28 \mathrm{E}+01$ & $4.19 \mathrm{E}+02$ & $2.45 \mathrm{E}+01$ \\
\hline $3.07 \mathrm{E}+02$ & $2.29 \mathrm{E}+01$ & $4.21 \mathrm{E}+02$ & $2.46 \mathrm{E}+01$ \\
\hline $3.09 \mathrm{E}+02$ & $2.29 \mathrm{E}+01$ & $4.23 \mathrm{E}+02$ & $2.47 \mathrm{E}+01$ \\
\hline $3.11 \mathrm{E}+02$ & $2.30 \mathrm{E}+01$ & $4.26 \mathrm{E}+02$ & $2.47 \mathrm{E}+01$ \\
\hline $3.14 \mathrm{E}+02$ & $2.31 \mathrm{E}+01$ & $4.28 \mathrm{E}+02$ & $2.47 \mathrm{E}+01$ \\
\hline $3.16 \mathrm{E}+02$ & $2.31 \mathrm{E}+01$ & $4.30 \mathrm{E}+02$ & $2.48 \mathrm{E}+01$ \\
\hline $3.18 \mathrm{E}+02$ & $2.31 \mathrm{E}+01$ & $4.32 \mathrm{E}+02$ & $2.49 \mathrm{E}+01$ \\
\hline $3.20 \mathrm{E}+02$ & $2.30 \mathrm{E}+01$ & $4.34 \mathrm{E}+02$ & $2.48 \mathrm{E}+01$ \\
\hline $3.22 \mathrm{E}+02$ & $2.31 \mathrm{E}+01$ & $4.37 \mathrm{E}+02$ & $2.49 \mathrm{E}+01$ \\
\hline $3.24 \mathrm{E}+02$ & $2.31 \mathrm{E}+01$ & $4.39 \mathrm{E}+02$ & $2.48 \mathrm{E}+01$ \\
\hline $3.26 \mathrm{E}+02$ & $2.31 \mathrm{E}+01$ & $4.41 \mathrm{E}+02$ & $2.47 \mathrm{E}+01$ \\
\hline $3.29 \mathrm{E}+02$ & $2.31 \mathrm{E}+01$ & $4.43 \mathrm{E}+02$ & $2.47 \mathrm{E}+01$ \\
\hline $3.31 \mathrm{E}+02$ & $2.32 \mathrm{E}+01$ & $4.45 \mathrm{E}+02$ & $2.47 \mathrm{E}+01$ \\
\hline $3.33 \mathrm{E}+02$ & $2.32 \mathrm{E}+01$ & $4.47 \mathrm{E}+02$ & $2.47 \mathrm{E}+01$ \\
\hline $3.35 \mathrm{E}+02$ & $2.33 \mathrm{E}+01$ & $4.50 \mathrm{E}+02$ & $2.48 \mathrm{E}+01$ \\
\hline $3.37 \mathrm{E}+02$ & $2.33 \mathrm{E}+01$ & $4.52 \mathrm{E}+02$ & $2.49 \mathrm{E}+01$ \\
\hline $3.40 \mathrm{E}+02$ & $2.34 \mathrm{E}+01$ & $4.54 \mathrm{E}+02$ & $2.50 \mathrm{E}+01$ \\
\hline $3.42 \mathrm{E}+02$ & $2.34 \mathrm{E}+01$ & $4.56 \mathrm{E}+02$ & $2.50 \mathrm{E}+01$ \\
\hline $3.44 \mathrm{E}+02$ & $2.36 \mathrm{E}+01$ & $4.58 \mathrm{E}+02$ & $2.49 \mathrm{E}+01$ \\
\hline $3.46 \mathrm{E}+02$ & $2.36 \mathrm{E}+01$ & $4.61 \mathrm{E}+02$ & $2.49 \mathrm{E}+01$ \\
\hline $3.48 \mathrm{E}+02$ & $2.37 \mathrm{E}+01$ & $4.63 \mathrm{E}+02$ & $2.45 \mathrm{E}+01$ \\
\hline $3.50 \mathrm{E}+02$ & $2.36 \mathrm{E}+01$ & $4.65 \mathrm{E}+02$ & $2.47 \mathrm{E}+01$ \\
\hline $3.53 \mathrm{E}+02$ & $2.36 \mathrm{E}+01$ & $4.67 \mathrm{E}+02$ & $2.47 \mathrm{E}+01$ \\
\hline $3.55 \mathrm{E}+02$ & $2.36 \mathrm{E}+01$ & $4.70 \mathrm{E}+02$ & $2.49 \mathrm{E}+01$ \\
\hline $3.57 \mathrm{E}+02$ & $2.38 \mathrm{E}+01$ & $4.72 \mathrm{E}+02$ & $2.49 \mathrm{E}+01$ \\
\hline $3.60 \mathrm{E}+02$ & $2.39 \mathrm{E}+01$ & $4.74 \mathrm{E}+02$ & $2.49 \mathrm{E}+01$ \\
\hline $3.62 \mathrm{E}+02$ & $2.39 \mathrm{E}+01$ & $4.76 \mathrm{E}+02$ & $2.48 \mathrm{E}+01$ \\
\hline $3.64 \mathrm{E}+02$ & $2.38 \mathrm{E}+01$ & $4.78 \mathrm{E}+02$ & $2.49 \mathrm{E}+01$ \\
\hline $3.65 \mathrm{E}+02$ & $2.39 \mathrm{E}+01$ & $4.80 \mathrm{E}+02$ & $2.51 \mathrm{E}+01$ \\
\hline $3.69 \mathrm{E}+02$ & $2.39 \mathrm{E}+01$ & $4.82 \mathrm{E}+02$ & $2.51 \mathrm{E}+01$ \\
\hline $3.71 \mathrm{E}+02$ & $2.40 \mathrm{E}+01$ & $4.86 \mathrm{E}+02$ & $2.51 \mathrm{E}+01$ \\
\hline $3.73 \mathrm{E}+02$ & $2.40 \mathrm{E}+01$ & $4.87 \mathrm{E}+02$ & $2.52 \mathrm{E}+01$ \\
\hline $3.75 \mathrm{E}+02$ & $2.40 \mathrm{E}+01$ & $4.90 \mathrm{E}+02$ & $2.52 \mathrm{E}+01$ \\
\hline $3.77 \mathrm{E}+02$ & $2.40 \mathrm{E}+01$ & $4.91 \mathrm{E}+02$ & $2.54 \mathrm{E}+01$ \\
\hline $3.80 \mathrm{E}+02$ & $2.40 \mathrm{E}+01$ & $4.94 \mathrm{E}+02$ & $2.53 \mathrm{E}+01$ \\
\hline $3.82 \mathrm{E}+02$ & $2.41 \mathrm{E}+01$ & $4.97 \mathrm{E}+02$ & $2.53 \mathrm{E}+01$ \\
\hline $3.84 \mathrm{E}+02$ & $2.42 \mathrm{E}+01$ & 4.99E+02 & $2.53 \mathrm{E}+01$ \\
\hline $3.86 \mathrm{E}+02$ & $2.42 \mathrm{E}+01$ & $5.01 \mathrm{E}+02$ & $2.54 \mathrm{E}+01$ \\
\hline $3.88 \mathrm{E}+02$ & $2.42 \mathrm{E}+01$ & $5.03 \mathrm{E}+02$ & $2.53 \mathrm{E}+01$ \\
\hline $3.91 \mathrm{E}+02$ & $2.43 \mathrm{E}+01$ & $5.05 \mathrm{E}+02$ & $2.54 \mathrm{E}+01$ \\
\hline $3.93 \mathrm{E}+02$ & $2.43 \mathrm{E}+01$ & $5.08 \mathrm{E}+02$ & $2.54 \mathrm{E}+01$ \\
\hline $3.95 \mathrm{E}+02$ & $2.42 \mathrm{E}+01$ & $5.10 \mathrm{E}+02$ & $2.54 \mathrm{E}+01$ \\
\hline $3.97 \mathrm{E}+02$ & $2.42 \mathrm{E}+01$ & $5.12 \mathrm{E}+02$ & $2.55 \mathrm{E}+01$ \\
\hline
\end{tabular}


Westinghouse Savannah River Company

WSRC-TR-2002-00302

Savannah River Technology Center

Page 50 of 64

\begin{tabular}{|l|l|l|l|}
\hline $3.99 \mathrm{E}+02$ & $2.41 \mathrm{E}+01$ & $5.14 \mathrm{E}+02$ & $2.54 \mathrm{E}+01$ \\
\hline $4.01 \mathrm{E}+02$ & $2.40 \mathrm{E}+01$ & $5.16 \mathrm{E}+02$ & $2.55 \mathrm{E}+01$ \\
\hline $4.04 \mathrm{E}+02$ & $2.42 \mathrm{E}+01$ & $5.19 \mathrm{E}+02$ & $2.55 \mathrm{E}+01$ \\
\hline
\end{tabular}


Westinghouse Savannah River Company

WSRC-TR-2002-00302

Savannah River Technology Center

Page 51 of 64

\begin{tabular}{|c|c|c|c|}
\hline$\underline{\mathrm{D}[1 / \mathrm{s}]}$ & Tau (Pa) & $\mathrm{D}[1 / \mathrm{s}]$ & $\underline{\text { Tau }(\mathbf{P a})}$ \\
\hline $5.21 \mathrm{E}+02$ & $2.55 \mathrm{E}+01$ & $6.35 \mathrm{E}+02$ & $2.65 \mathrm{E}+01$ \\
\hline $5.23 \mathrm{E}+02$ & $2.55 \mathrm{E}+01$ & $6.37 \mathrm{E}+02$ & $2.65 \mathrm{E}+01$ \\
\hline $5.25 \mathrm{E}+02$ & $2.55 \mathrm{E}+01$ & $6.40 \mathrm{E}+02$ & $2.64 \mathrm{E}+01$ \\
\hline $5.27 \mathrm{E}+02$ & $2.56 \mathrm{E}+01$ & $6.42 \mathrm{E}+02$ & $2.65 \mathrm{E}+01$ \\
\hline $5.29 \mathrm{E}+02$ & $2.55 \mathrm{E}+01$ & $6.44 \mathrm{E}+02$ & $2.65 \mathrm{E}+01$ \\
\hline $5.32 \mathrm{E}+02$ & $2.54 \mathrm{E}+01$ & $6.46 \mathrm{E}+02$ & $2.65 \mathrm{E}+01$ \\
\hline $5.34 \mathrm{E}+02$ & $2.55 \mathrm{E}+01$ & $6.48 \mathrm{E}+02$ & $2.66 \mathrm{E}+01$ \\
\hline $5.36 \mathrm{E}+02$ & $2.56 \mathrm{E}+01$ & $6.50 \mathrm{E}+02$ & $2.66 \mathrm{E}+01$ \\
\hline $5.38 \mathrm{E}+02$ & $2.56 \mathrm{E}+01$ & $6.53 \mathrm{E}+02$ & $2.66 \mathrm{E}+01$ \\
\hline $5.40 \mathrm{E}+02$ & $2.57 \mathrm{E}+01$ & $6.55 \mathrm{E}+02$ & $2.66 \mathrm{E}+01$ \\
\hline $5.44 \mathrm{E}+02$ & $2.59 \mathrm{E}+01$ & $6.57 \mathrm{E}+02$ & $2.66 \mathrm{E}+01$ \\
\hline $5.45 \mathrm{E}+02$ & $2.59 \mathrm{E}+01$ & $6.59 \mathrm{E}+02$ & $2.65 \mathrm{E}+01$ \\
\hline $5.47 \mathrm{E}+02$ & $2.58 \mathrm{E}+01$ & $6.61 \mathrm{E}+02$ & $2.65 \mathrm{E}+01$ \\
\hline $5.49 \mathrm{E}+02$ & $2.58 \mathrm{E}+01$ & $6.64 \mathrm{E}+02$ & $2.65 \mathrm{E}+01$ \\
\hline $5.51 \mathrm{E}+02$ & $2.59 \mathrm{E}+01$ & $6.66 \mathrm{E}+02$ & $2.65 \mathrm{E}+01$ \\
\hline $5.53 \mathrm{E}+02$ & $2.60 \mathrm{E}+01$ & $6.68 \mathrm{E}+02$ & $2.66 \mathrm{E}+01$ \\
\hline $5.55 \mathrm{E}+02$ & $2.60 \mathrm{E}+01$ & $6.70 \mathrm{E}+02$ & $2.66 \mathrm{E}+01$ \\
\hline $5.58 \mathrm{E}+02$ & $2.60 \mathrm{E}+01$ & $6.72 \mathrm{E}+02$ & $2.65 \mathrm{E}+01$ \\
\hline $5.60 \mathrm{E}+02$ & $2.60 \mathrm{E}+01$ & $6.75 \mathrm{E}+02$ & $2.66 \mathrm{E}+01$ \\
\hline $5.62 \mathrm{E}+02$ & $2.60 \mathrm{E}+01$ & $6.77 \mathrm{E}+02$ & $2.66 \mathrm{E}+01$ \\
\hline $5.64 \mathrm{E}+02$ & $2.61 \mathrm{E}+01$ & $6.79 \mathrm{E}+02$ & $2.66 \mathrm{E}+01$ \\
\hline $5.66 \mathrm{E}+02$ & $2.61 \mathrm{E}+01$ & $6.81 \mathrm{E}+02$ & $2.67 \mathrm{E}+01$ \\
\hline $5.68 \mathrm{E}+02$ & $2.61 \mathrm{E}+01$ & $6.83 \mathrm{E}+02$ & $2.67 \mathrm{E}+01$ \\
\hline $5.71 \mathrm{E}+02$ & $2.62 \mathrm{E}+01$ & $6.85 \mathrm{E}+02$ & $2.68 \mathrm{E}+01$ \\
\hline $5.73 \mathrm{E}+02$ & $2.62 \mathrm{E}+01$ & $6.88 \mathrm{E}+02$ & $2.68 \mathrm{E}+01$ \\
\hline $5.75 \mathrm{E}+02$ & $2.62 \mathrm{E}+01$ & $6.90 \mathrm{E}+02$ & $2.68 \mathrm{E}+01$ \\
\hline $5.77 \mathrm{E}+02$ & $2.63 \mathrm{E}+01$ & $6.92 \mathrm{E}+02$ & $2.68 \mathrm{E}+01$ \\
\hline $5.79 \mathrm{E}+02$ & $2.63 \mathrm{E}+01$ & $6.94 \mathrm{E}+02$ & $2.68 \mathrm{E}+01$ \\
\hline $5.82 \mathrm{E}+02$ & $2.63 \mathrm{E}+01$ & $6.96 \mathrm{E}+02$ & $2.68 \mathrm{E}+01$ \\
\hline $5.84 \mathrm{E}+02$ & $2.63 \mathrm{E}+01$ & $6.99 \mathrm{E}+02$ & $2.69 \mathrm{E}+01$ \\
\hline $5.86 \mathrm{E}+02$ & $2.63 \mathrm{E}+01$ & $7.01 \mathrm{E}+02$ & $2.69 \mathrm{E}+01$ \\
\hline $5.88 \mathrm{E}+02$ & $2.65 \mathrm{E}+01$ & $7.03 \mathrm{E}+02$ & $2.69 \mathrm{E}+01$ \\
\hline $5.90 \mathrm{E}+02$ & $2.64 \mathrm{E}+01$ & $7.05 \mathrm{E}+02$ & $2.70 \mathrm{E}+01$ \\
\hline $5.93 \mathrm{E}+02$ & $2.64 \mathrm{E}+01$ & $7.07 \mathrm{E}+02$ & $2.69 \mathrm{E}+01$ \\
\hline $5.95 \mathrm{E}+02$ & $2.64 \mathrm{E}+01$ & $7.10 \mathrm{E}+02$ & $2.70 \mathrm{E}+01$ \\
\hline $5.97 \mathrm{E}+02$ & $2.64 \mathrm{E}+01$ & $7.12 \mathrm{E}+02$ & $2.70 \mathrm{E}+01$ \\
\hline $5.99 \mathrm{E}+02$ & $2.64 \mathrm{E}+01$ & $7.14 \mathrm{E}+02$ & $2.70 \mathrm{E}+01$ \\
\hline $6.01 \mathrm{E}+02$ & $2.64 \mathrm{E}+01$ & $7.16 \mathrm{E}+02$ & $2.71 \mathrm{E}+01$ \\
\hline $6.03 \mathrm{E}+02$ & $2.65 \mathrm{E}+01$ & $7.18 \mathrm{E}+02$ & $2.70 \mathrm{E}+01$ \\
\hline $6.06 \mathrm{E}+02$ & $2.67 \mathrm{E}+01$ & $7.21 \mathrm{E}+02$ & $2.71 \mathrm{E}+01$ \\
\hline $6.08 \mathrm{E}+02$ & $2.68 \mathrm{E}+01$ & $7.23 \mathrm{E}+02$ & $2.70 \mathrm{E}+01$ \\
\hline $6.11 \mathrm{E}+02$ & $2.67 \mathrm{E}+01$ & $7.25 \mathrm{E}+02$ & $2.70 \mathrm{E}+01$ \\
\hline $6.12 \mathrm{E}+02$ & $2.67 \mathrm{E}+01$ & $7.27 \mathrm{E}+02$ & $2.70 \mathrm{E}+01$ \\
\hline $6.15 \mathrm{E}+02$ & $2.67 \mathrm{E}+01$ & $7.29 \mathrm{E}+02$ & $2.71 \mathrm{E}+01$ \\
\hline $6.18 \mathrm{E}+02$ & $2.66 \mathrm{E}+01$ & $7.31 \mathrm{E}+02$ & $2.70 \mathrm{E}+01$ \\
\hline $6.20 \mathrm{E}+02$ & $2.66 \mathrm{E}+01$ & $7.34 \mathrm{E}+02$ & $2.71 \mathrm{E}+01$ \\
\hline $6.22 \mathrm{E}+02$ & $2.66 \mathrm{E}+01$ & $7.36 \mathrm{E}+02$ & $2.72 \mathrm{E}+01$ \\
\hline $6.24 \mathrm{E}+02$ & $2.66 \mathrm{E}+01$ & $7.38 \mathrm{E}+02$ & $2.72 \mathrm{E}+01$ \\
\hline $6.26 \mathrm{E}+02$ & $2.65 \mathrm{E}+01$ & $7.40 \mathrm{E}+02$ & $2.72 \mathrm{E}+01$ \\
\hline $6.29 \mathrm{E}+02$ & $2.67 \mathrm{E}+01$ & $7.42 \mathrm{E}+02$ & $2.73 \mathrm{E}+01$ \\
\hline
\end{tabular}


Westinghouse Savannah River Company

WSRC-TR-2002-00302

Savannah River Technology Center

Page 52 of 64

\begin{tabular}{|c|c|c|c|}
\hline $6.31 \mathrm{E}+02$ & $2.66 \mathrm{E}+01$ & $7.45 \mathrm{E}+02$ & $2.73 \mathrm{E}+01$ \\
\hline $6.33 \mathrm{E}+02$ & $2.66 \mathrm{E}+01$ & $7.47 \mathrm{E}+02$ & $2.73 \mathrm{E}+01$ \\
\hline$\underline{\mathrm{D}[1 / \mathrm{s}]}$ & Tau (Pa) & $\mathrm{D}[1 / \mathrm{s}]$ & $\underline{\text { Tau }(\mathbf{P a})}$ \\
\hline $7.49 \mathrm{E}+02$ & $2.73 \mathrm{E}+01$ & $8.64 \mathrm{E}+02$ & $2.82 \mathrm{E}+01$ \\
\hline $7.51 \mathrm{E}+02$ & $2.73 \mathrm{E}+01$ & $8.66 \mathrm{E}+02$ & $2.82 \mathrm{E}+01$ \\
\hline $7.54 \mathrm{E}+02$ & $2.73 \mathrm{E}+01$ & $8.68 \mathrm{E}+02$ & $2.82 \mathrm{E}+01$ \\
\hline $7.56 \mathrm{E}+02$ & $2.74 \mathrm{E}+01$ & $8.71 \mathrm{E}+02$ & $2.83 \mathrm{E}+01$ \\
\hline $7.59 \mathrm{E}+02$ & $2.74 \mathrm{E}+01$ & $8.73 \mathrm{E}+02$ & $2.83 \mathrm{E}+01$ \\
\hline $7.61 \mathrm{E}+02$ & $2.74 \mathrm{E}+01$ & $8.75 \mathrm{E}+02$ & $2.83 \mathrm{E}+01$ \\
\hline $7.63 \mathrm{E}+02$ & $2.74 \mathrm{E}+01$ & $8.77 \mathrm{E}+02$ & $2.84 \mathrm{E}+01$ \\
\hline $7.65 \mathrm{E}+02$ & $2.74 \mathrm{E}+01$ & $8.79 \mathrm{E}+02$ & $2.84 \mathrm{E}+01$ \\
\hline $7.67 \mathrm{E}+02$ & $2.74 \mathrm{E}+01$ & $8.82 \mathrm{E}+02$ & $2.84 \mathrm{E}+01$ \\
\hline $7.70 \mathrm{E}+02$ & $2.75 \mathrm{E}+01$ & $8.84 \mathrm{E}+02$ & $2.83 \mathrm{E}+01$ \\
\hline $7.71 \mathrm{E}+02$ & $2.75 \mathrm{E}+01$ & $8.86 \mathrm{E}+02$ & $2.83 \mathrm{E}+01$ \\
\hline $7.74 \mathrm{E}+02$ & $2.75 \mathrm{E}+01$ & $8.88 \mathrm{E}+02$ & $2.84 \mathrm{E}+01$ \\
\hline $7.76 \mathrm{E}+02$ & $2.75 \mathrm{E}+01$ & $8.90 \mathrm{E}+02$ & $2.84 \mathrm{E}+01$ \\
\hline $7.78 \mathrm{E}+02$ & $2.76 \mathrm{E}+01$ & $8.92 \mathrm{E}+02$ & $2.85 \mathrm{E}+01$ \\
\hline $7.81 \mathrm{E}+02$ & $2.76 \mathrm{E}+01$ & $8.95 \mathrm{E}+02$ & $2.85 \mathrm{E}+01$ \\
\hline $7.83 \mathrm{E}+02$ & $2.76 \mathrm{E}+01$ & $8.97 \mathrm{E}+02$ & $2.85 \mathrm{E}+01$ \\
\hline $7.85 \mathrm{E}+02$ & $2.76 \mathrm{E}+01$ & $8.99 \mathrm{E}+02$ & $2.85 \mathrm{E}+01$ \\
\hline $7.87 \mathrm{E}+02$ & $2.76 \mathrm{E}+01$ & $9.01 \mathrm{E}+02$ & $2.85 \mathrm{E}+01$ \\
\hline $7.89 \mathrm{E}+02$ & $2.77 \mathrm{E}+01$ & $9.03 \mathrm{E}+02$ & $2.85 \mathrm{E}+01$ \\
\hline $7.92 \mathrm{E}+02$ & $2.76 \mathrm{E}+01$ & $9.06 \mathrm{E}+02$ & $2.85 \mathrm{E}+01$ \\
\hline $7.94 \mathrm{E}+02$ & $2.76 \mathrm{E}+01$ & $9.08 \mathrm{E}+02$ & $2.85 \mathrm{E}+01$ \\
\hline $7.96 \mathrm{E}+02$ & $2.77 \mathrm{E}+01$ & $9.10 \mathrm{E}+02$ & $2.85 \mathrm{E}+01$ \\
\hline $7.98 \mathrm{E}+02$ & $2.76 \mathrm{E}+01$ & $9.12 \mathrm{E}+02$ & $2.87 \mathrm{E}+01$ \\
\hline $8.00 \mathrm{E}+02$ & $2.76 \mathrm{E}+01$ & $9.14 \mathrm{E}+02$ & $2.87 \mathrm{E}+01$ \\
\hline $8.03 E+02$ & $2.76 \mathrm{E}+01$ & $9.17 \mathrm{E}+02$ & $2.87 \mathrm{E}+01$ \\
\hline $8.05 \mathrm{E}+02$ & $2.76 \mathrm{E}+01$ & $9.19 \mathrm{E}+02$ & $2.86 \mathrm{E}+01$ \\
\hline $8.07 \mathrm{E}+02$ & $2.77 \mathrm{E}+01$ & $9.21 \mathrm{E}+02$ & $2.86 \mathrm{E}+01$ \\
\hline $8.09 \mathrm{E}+02$ & $2.78 \mathrm{E}+01$ & $9.24 \mathrm{E}+02$ & $2.86 \mathrm{E}+01$ \\
\hline $8.11 \mathrm{E}+02$ & $2.78 \mathrm{E}+01$ & $9.25 \mathrm{E}+02$ & $2.86 \mathrm{E}+01$ \\
\hline $8.13 \mathrm{E}+02$ & $2.78 \mathrm{E}+01$ & $9.28 \mathrm{E}+02$ & $2.86 \mathrm{E}+01$ \\
\hline $8.16 \mathrm{E}+02$ & $2.78 \mathrm{E}+01$ & $9.30 \mathrm{E}+02$ & $2.86 \mathrm{E}+01$ \\
\hline $8.18 \mathrm{E}+02$ & $2.79 \mathrm{E}+01$ & $9.33 \mathrm{E}+02$ & $2.87 \mathrm{E}+01$ \\
\hline $8.20 \mathrm{E}+02$ & $2.79 \mathrm{E}+01$ & $9.34 \mathrm{E}+02$ & $2.88 \mathrm{E}+01$ \\
\hline $8.22 \mathrm{E}+02$ & $2.80 \mathrm{E}+01$ & $9.37 \mathrm{E}+02$ & $2.87 \mathrm{E}+01$ \\
\hline $8.25 \mathrm{E}+02$ & $2.79 \mathrm{E}+01$ & $9.39 \mathrm{E}+02$ & $2.87 \mathrm{E}+01$ \\
\hline $8.27 \mathrm{E}+02$ & $2.79 \mathrm{E}+01$ & $9.42 \mathrm{E}+02$ & $2.88 \mathrm{E}+01$ \\
\hline $8.29 \mathrm{E}+02$ & $2.79 \mathrm{E}+01$ & $9.44 \mathrm{E}+02$ & $2.88 \mathrm{E}+01$ \\
\hline $8.31 \mathrm{E}+02$ & $2.80 \mathrm{E}+01$ & $9.46 \mathrm{E}+02$ & $2.87 \mathrm{E}+01$ \\
\hline $8.33 \mathrm{E}+02$ & $2.79 \mathrm{E}+01$ & $9.48 \mathrm{E}+02$ & $2.88 \mathrm{E}+01$ \\
\hline $8.36 \mathrm{E}+02$ & $2.79 \mathrm{E}+01$ & $9.50 \mathrm{E}+02$ & $2.88 \mathrm{E}+01$ \\
\hline $8.38 \mathrm{E}+02$ & $2.79 \mathrm{E}+01$ & $9.53 \mathrm{E}+02$ & $2.89 \mathrm{E}+01$ \\
\hline $8.40 \mathrm{E}+02$ & $2.79 \mathrm{E}+01$ & $9.55 \mathrm{E}+02$ & $2.88 \mathrm{E}+01$ \\
\hline $8.42 \mathrm{E}+02$ & $2.79 \mathrm{E}+01$ & $9.57 \mathrm{E}+02$ & $2.88 \mathrm{E}+01$ \\
\hline $8.44 \mathrm{E}+02$ & $2.80 \mathrm{E}+01$ & $9.59 \mathrm{E}+02$ & $2.88 \mathrm{E}+01$ \\
\hline $8.46 \mathrm{E}+02$ & $2.80 \mathrm{E}+01$ & $9.61 \mathrm{E}+02$ & $2.88 \mathrm{E}+01$ \\
\hline $8.49 \mathrm{E}+02$ & $2.81 \mathrm{E}+01$ & $9.64 \mathrm{E}+02$ & $2.88 \mathrm{E}+01$ \\
\hline $8.51 \mathrm{E}+02$ & $2.81 \mathrm{E}+01$ & $9.66 \mathrm{E}+02$ & $2.89 \mathrm{E}+01$ \\
\hline $8.53 \mathrm{E}+02$ & $2.81 \mathrm{E}+01$ & $9.68 \mathrm{E}+02$ & $2.89 \mathrm{E}+01$ \\
\hline $8.55 \mathrm{E}+02$ & $2.82 \mathrm{E}+01$ & $9.70 \mathrm{E}+02$ & $2.89 \mathrm{E}+01$ \\
\hline
\end{tabular}


Westinghouse Savannah River Company

WSRC-TR-2002-00302

Savannah River Technology Center

Page 53 of 64

\begin{tabular}{|l|l|l|l|}
\hline $8.57 \mathrm{E}+02$ & $2.81 \mathrm{E}+01$ & $9.72 \mathrm{E}+02$ & $2.89 \mathrm{E}+01$ \\
\hline $8.60 \mathrm{E}+02$ & $2.82 \mathrm{E}+01$ & $9.74 \mathrm{E}+02$ & $2.90 \mathrm{E}+01$ \\
\hline $8.62 \mathrm{E}+02$ & $2.82 \mathrm{E}+01$ & $9.77 \mathrm{E}+02$ & $2.90 \mathrm{E}+01$ \\
\hline
\end{tabular}


Westinghouse Savannah River Company

WSRC-TR-2002-00302

Savannah River Technology Center

Page 54 of 64

\begin{tabular}{|c|c|c|c|}
\hline$\underline{\mathrm{D}[1 / \mathrm{s}]}$ & Tau (Pa) & $\underline{\mathrm{D}[1 / \mathrm{s}]}$ & $\underline{\text { Tau }(\mathbf{P a})}$ \\
\hline $9.79 \mathrm{E}+02$ & $2.90 \mathrm{E}+01$ & $1.04 \mathrm{E}+03$ & $2.92 \mathrm{E}+01$ \\
\hline $9.81 \mathrm{E}+02$ & $2.90 \mathrm{E}+01$ & $1.04 \mathrm{E}+03$ & $2.93 \mathrm{E}+01$ \\
\hline $9.83 \mathrm{E}+02$ & $2.90 \mathrm{E}+01$ & $1.04 \mathrm{E}+03$ & $2.94 \mathrm{E}+01$ \\
\hline $9.85 \mathrm{E}+02$ & $2.91 \mathrm{E}+01$ & $1.04 \mathrm{E}+03$ & $2.94 \mathrm{E}+01$ \\
\hline $9.87 \mathrm{E}+02$ & $2.91 \mathrm{E}+01$ & $1.05 \mathrm{E}+03$ & $2.94 \mathrm{E}+01$ \\
\hline $9.90 \mathrm{E}+02$ & $2.91 \mathrm{E}+01$ & $1.05 \mathrm{E}+03$ & $2.94 \mathrm{E}+01$ \\
\hline $9.92 \mathrm{E}+02$ & $2.91 \mathrm{E}+01$ & $1.05 \mathrm{E}+03$ & $2.95 \mathrm{E}+01$ \\
\hline $9.94 \mathrm{E}+02$ & $2.91 \mathrm{E}+01$ & $1.05 \mathrm{E}+03$ & $2.95 \mathrm{E}+01$ \\
\hline $9.96 \mathrm{E}+02$ & $2.91 \mathrm{E}+01$ & $1.05 \mathrm{E}+03$ & $2.95 \mathrm{E}+01$ \\
\hline $9.98 \mathrm{E}+02$ & $2.91 \mathrm{E}+01$ & $1.06 \mathrm{E}+03$ & $2.95 \mathrm{E}+01$ \\
\hline $1.00 \mathrm{E}+03$ & $2.91 \mathrm{E}+01$ & $1.06 \mathrm{E}+03$ & $2.95 \mathrm{E}+01$ \\
\hline $1.00 \mathrm{E}+03$ & $2.92 \mathrm{E}+01$ & $1.06 \mathrm{E}+03$ & $2.95 \mathrm{E}+01$ \\
\hline $1.01 \mathrm{E}+03$ & $2.92 \mathrm{E}+01$ & $1.06 \mathrm{E}+03$ & $2.96 \mathrm{E}+01$ \\
\hline $1.01 \mathrm{E}+03$ & $2.92 \mathrm{E}+01$ & $1.07 \mathrm{E}+03$ & $2.96 \mathrm{E}+01$ \\
\hline $1.01 \mathrm{E}+03$ & $2.91 \mathrm{E}+01$ & $1.07 \mathrm{E}+03$ & $2.96 \mathrm{E}+01$ \\
\hline $1.01 \mathrm{E}+03$ & $2.91 \mathrm{E}+01$ & $1.07 \mathrm{E}+03$ & $2.96 \mathrm{E}+01$ \\
\hline $1.01 \mathrm{E}+03$ & $2.92 \mathrm{E}+01$ & $1.07 \mathrm{E}+03$ & $2.96 \mathrm{E}+01$ \\
\hline $1.02 \mathrm{E}+03$ & $2.92 \mathrm{E}+01$ & $1.07 \mathrm{E}+03$ & $2.96 \mathrm{E}+01$ \\
\hline $1.02 \mathrm{E}+03$ & $2.92 \mathrm{E}+01$ & $1.08 \mathrm{E}+03$ & $2.97 \mathrm{E}+01$ \\
\hline $1.02 \mathrm{E}+03$ & $2.93 \mathrm{E}+01$ & $1.08 \mathrm{E}+03$ & $2.97 \mathrm{E}+01$ \\
\hline $1.02 \mathrm{E}+03$ & $2.92 \mathrm{E}+01$ & $1.08 \mathrm{E}+03$ & $2.97 \mathrm{E}+01$ \\
\hline $1.03 \mathrm{E}+03$ & $2.93 \mathrm{E}+01$ & $1.08 \mathrm{E}+03$ & $2.97 \mathrm{E}+01$ \\
\hline $1.03 \mathrm{E}+03$ & $2.93 \mathrm{E}+01$ & $1.09 \mathrm{E}+03$ & $2.97 \mathrm{E}+01$ \\
\hline $1.03 \mathrm{E}+03$ & $2.93 \mathrm{E}+01$ & $1.09 \mathrm{E}+03$ & $2.98 \mathrm{E}+01$ \\
\hline $1.03 \mathrm{E}+03$ & $2.93 \mathrm{E}+01$ & $1.09 \mathrm{E}+03$ & $2.98 \mathrm{E}+01$ \\
\hline $1.03 \mathrm{E}+03$ & $2.92 \mathrm{E}+01$ & $1.09 \mathrm{E}+03$ & $3.00 \mathrm{E}+01$ \\
\hline
\end{tabular}




\section{APPENDIX C - DESCRIPTION OF THE INSTRUMENT USED TO PERFORM THE GFPS NONRADIAOCTIVE RHEOLOGY MEASUREMENTS AND FLOW CURVES OBTAINED FOR THE SLUDGE SLURRY AND SRAT PRODUCT}

The ThermoHaake RS150 RheoStress rheometer was used for recent measurements of SB2 simulant rheological properties. The general features of this rheometer have been discussed elsewhere, e.g. WSRC-TR-2002-00186. Items specific to the recent measurements are described here. The Z41 cylinder with the DZ43 cup was selected to give a vertical, concentric cylinder geometry that is very similar to the MVI configuration on the RV20 and RV30 rheometers. This configuration is preferred when particles of frit size are not a major issue.

The effective sample geometry is an annulus with inner and outer radii of 20.710-mm and 21.700-mm, with a length of 55-mm. The Z41 cylinder is hollowed out on the bottom like the MVI. Loading the cylinder into the sample creates a large air bubble on the underside of the sample. Consequently, very little of the measured torque is due to contact of the bottom of the cylinder with fluid in the bottom of the cup. Visual inspection following a measurement generally showed a dry, shiny surface on the bottom of the cylinder. In rare cases there was a drop of sludge on the underside, with the balance clean and shiny. Samples were also trimmed at the top if necessary. Even with trimming, there was generally a meniscus in the annular gap that may have extended one millimeter above the top of the 55-mm contact surface on the inner cylinder. This could cause a slightly higher torque reading than if the meniscus were not present. The fact that the cylinder is $55-\mathrm{mm}$ long is primarily to mitigate this effect by minimizing the magnitude of meniscus torque relative to that of the torque being drawn to overcome resistance within the annular gap.

Samples were linearly ramped in shear rate from $0 \mathrm{sec}^{-1}$ to $990 \mathrm{sec}^{-1}$ (the upper limit of the RS150 in the Z41 configuration). The ramping occurred over a five minute period. Samples were then held at $990 \mathrm{sec}^{-1}$ for one minute. Then the samples were linearly ramped down in shear rate to $0 \mathrm{sec}^{-1}$ over five minutes. Little variation was seen between up and down ramp data for the individual SB2 simulated, washed sludge samples. The sample at $13.5 \mathrm{wt}$. \% total solids showed evidence of Taylor vortices at about $870 \mathrm{sec}^{-1}$. Slightly larger variations were seen between up and down ramp SRAT product simulant data. The up ramp curves were not as smooth as, and slightly above, the down ramp curves. There was a more noticeable separation between the up and down ramp data, though it was still not unusual compared to past data. Measurements were made at $25^{\circ} \mathrm{C}$.

The uncorrected flow curves obtained for the sludge slurry samples are presented in Figure $\mathrm{C}$ - 1. Figure $\mathrm{C}$ - 2 is a comparison of the flow curves for the nonradioactive sludge slurry samples to the DWPF operating region.

The uncorrected flow curves for the SRAT product samples are presented in Figure C - 3. Figure C - 4 is a comparison of the flow curves for the nonradioactive SRAT samples to the DWPF operating region.

Figure C - 5 is a comparison of the flow curves for the nonradioactive SME samples to the DWPF operating region. 
Westinghouse Savannah River Company

WSRC-TR-2002-00302

Savannah River Technology Center

Page 56 of 64

Figure C - 1 - Uncorrected Flow Curves for the Sludge Slurry Samples from the GFPS

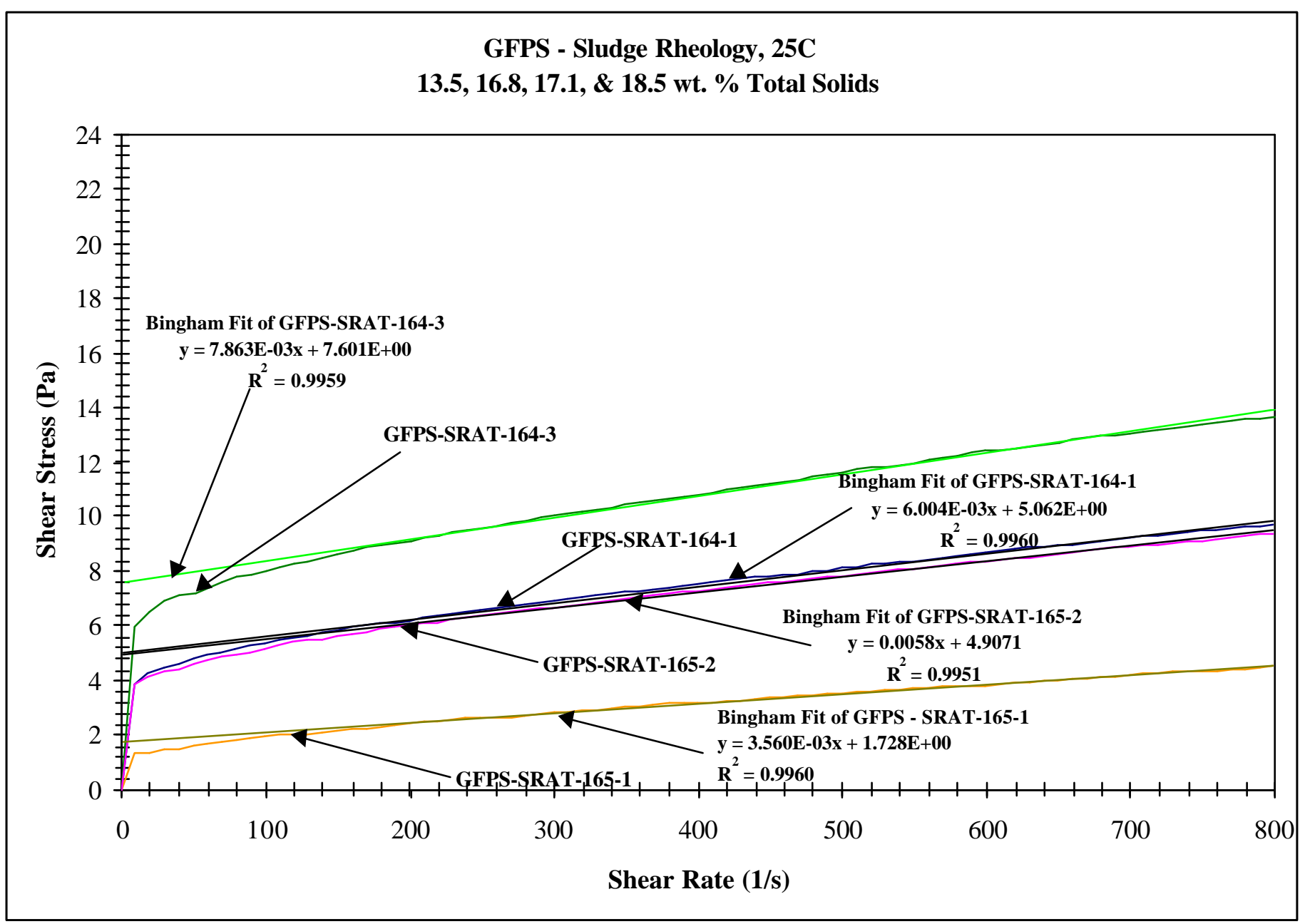


Westinghouse Savannah River Company

WSRC-TR-2002-00302

Savannah River Technology Center

Page 57 of 64

Figure C - 2 - Comparison of the Uncorrected Flow Curves for the GFPS Sludge Slurry Samples to the DWPF Operating Region

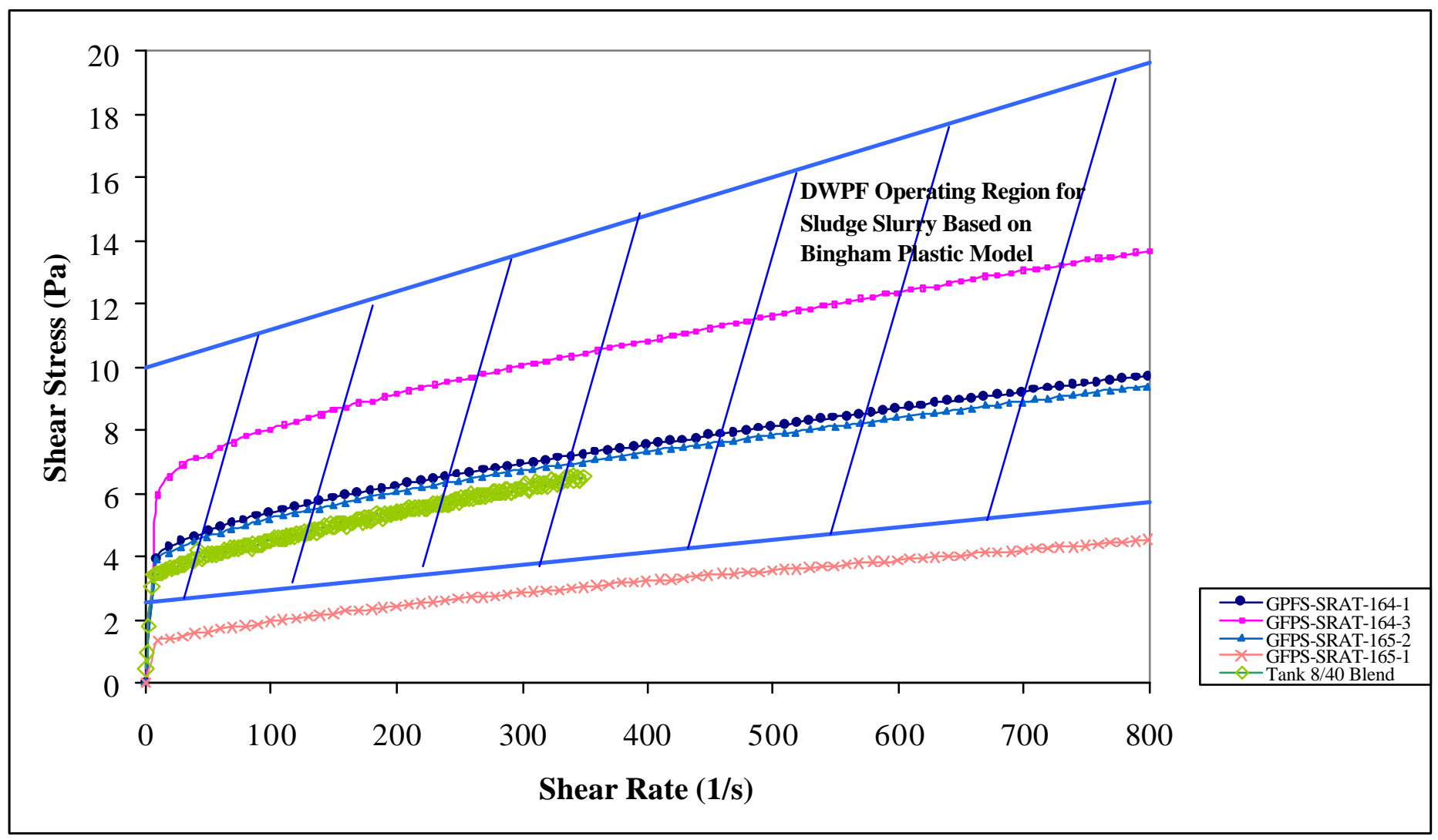


Figure C - 3 - Uncorrected Flow Curves for the SRAT Product Samples from the GFPS

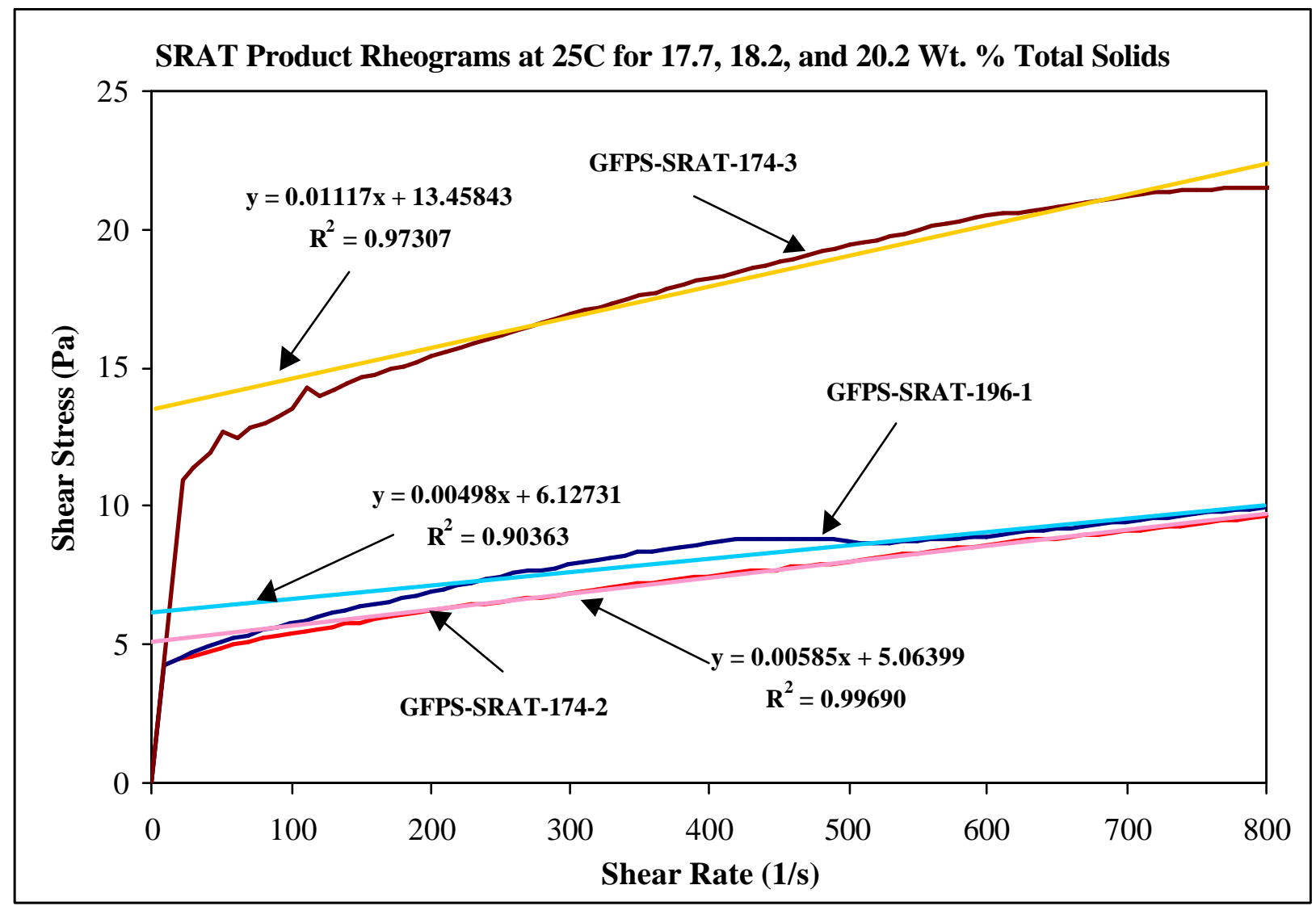


Westinghouse Savannah River Company

WSRC-TR-2002-00302

Savannah River Technology Center

Page 59 of 64

Figure C - 4 - Comparison of the Uncorrected Flow Curves for the GFPS SRAT Samples to the DWPF Operating Region

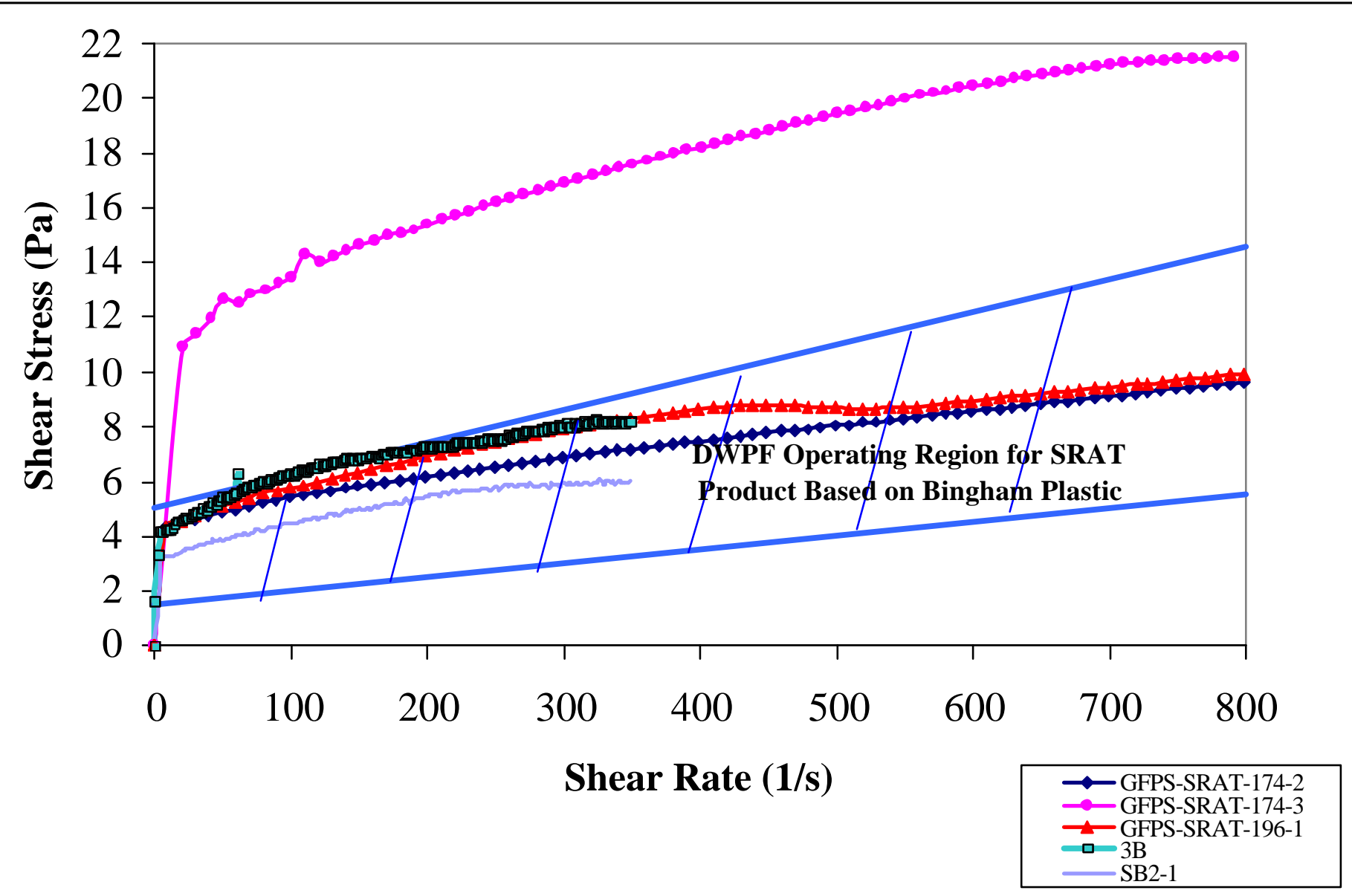


Westinghouse Savannah River Company

WSRC-TR-2002-00302

Savannah River Technology Center

Page 60 of 64

Figure C - 5 - Comparison of the Uncorrected Flow Curves for the Nonradioactive SME Samples to the DWPF Operating Region

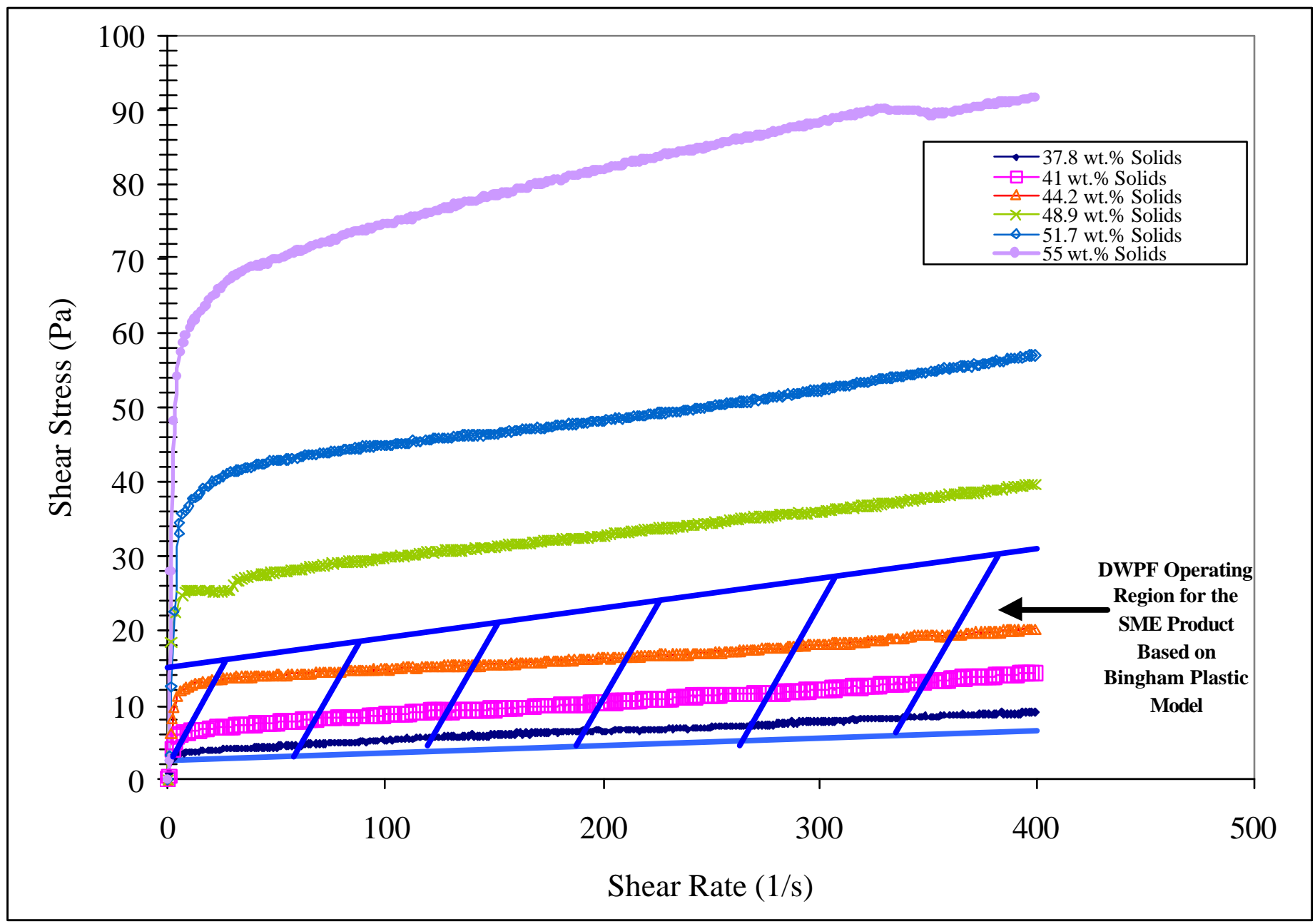


Westinghouse Savannah River Company

WSRC-TR-2002-00302

Savannah River Technology Center

Page 61 of 64

APPENDIX D - RAW DATA FOR THE GFPS SLUDE SLURRY SAMPLES AND SRAT PRODUCT SAMPLES (UP FLOW CURVES ONLY) 
Westinghouse Savannah River Company

WSRC-TR-2002-00302

Savannah River Technology Center

Page 62 of 64

GFPS-SRAT-164-1 (decanted sludge at $17.1 \mathrm{wt} \%$ TS)

ThermoHaake RheoWin 3/14/02 / 1:08 PM

Company: SRS Operator: dck

Date: 14.03.2002 Time: 12:53:40 PM Version: RheoWin Pro 291

Substance: 164 Sample no: 1

\begin{tabular}{|c|c|c|c|}
\hline $\mathrm{D}[1 / \mathrm{s}]$ & $\underline{\mathrm{Tau}}[\mathrm{Pa}]$ & $\underline{D}[1 / s]$ & $\underline{\text { Tau }[\mathrm{Pa}]}$ \\
\hline 0 & 0 & 499.1 & 8.12 \\
\hline 0 & 0 & 509 & 8.17 \\
\hline 0 & 0 & 519.8 & 8.239 \\
\hline 8.647 & 3.894 & 528.9 & 8.283 \\
\hline 18.79 & 4.279 & 539.1 & 8.341 \\
\hline 28.77 & 4.494 & 548.7 & 8.409 \\
\hline 39.17 & 4.642 & 559.1 & 8.453 \\
\hline 49.49 & 4.797 & 568.9 & 8.51 \\
\hline 59.06 & 4.922 & 578.8 & 8.559 \\
\hline 68.56 & 5.033 & 588.7 & 8.637 \\
\hline 78.82 & 5.153 & 598.8 & 8.698 \\
\hline 88.93 & 5.274 & 608.8 & 8.738 \\
\hline 98.82 & 5.374 & 618.6 & 8.796 \\
\hline 109.2 & 5.463 & 628.6 & 8.848 \\
\hline 118.6 & 5.572 & 639.3 & 8.897 \\
\hline 128.9 & 5.657 & 648.9 & 8.964 \\
\hline 138.7 & 5.742 & 659 & 9.015 \\
\hline 149.2 & 5.843 & 668.7 & 9.059 \\
\hline 158.9 & 5.927 & 678.8 & 9.119 \\
\hline 168.9 & 6.004 & 689.1 & 9.157 \\
\hline 178.7 & 6.076 & 699.3 & 9.221 \\
\hline 189.1 & 6.15 & 709 & 9.27 \\
\hline 199.2 & 6.222 & 719.1 & 9.321 \\
\hline 209.2 & 6.305 & 729 & 9.371 \\
\hline 219.2 & 6.386 & 739 & 9.428 \\
\hline 229.2 & 6.447 & 748.4 & 9.475 \\
\hline 239 & 6.526 & 758.9 & 9.53 \\
\hline 248.5 & 6.581 & 768.9 & 9.579 \\
\hline 258.7 & 6.65 & 778.8 & 9.632 \\
\hline 268.9 & 6.727 & 789.3 & 9.69 \\
\hline 279.1 & 6.782 & 798.7 & 9.724 \\
\hline 288.9 & 6.855 & 809.8 & 9.785 \\
\hline 299.2 & 6.927 & 818.6 & 9.82 \\
\hline 309.3 & 6.989 & 829 & 9.892 \\
\hline 318.9 & 7.051 & 838.8 & 9.939 \\
\hline 328.9 & 7.126 & 848.8 & 9.983 \\
\hline 339.6 & 7.177 & 858.7 & 10.04 \\
\hline 348.9 & 7.235 & 868.8 & 10.08 \\
\hline 358.8 & 7.298 & 879.2 & 10.14 \\
\hline 369.3 & 7.355 & 888.8 & 10.19 \\
\hline 379 & 7.417 & 898.8 & 10.25 \\
\hline 389 & 7.474 & 908.8 & 10.29 \\
\hline 398.6 & 7.529 & 918.7 & 10.34 \\
\hline 408.5 & 7.588 & 928.7 & 10.39 \\
\hline 418.8 & 7.648 & 938.7 & 10.44 \\
\hline 428.7 & 7.703 & 949.2 & 10.48 \\
\hline
\end{tabular}


Westinghouse Savannah River Company

WSRC-TR-2002-00302

Savannah River Technology Center

Page 63 of 64

\begin{tabular}{|c|c|c|c|}
\hline 438.9 & 7.758 & 959.4 & 10.55 \\
\hline 448.6 & 7.826 & 969 & 10.59 \\
\hline 458.7 & 7.881 & 978.6 & 10.63 \\
\hline 469 & 7.926 & 989.3 & 10.74 \\
\hline 479.1 & 7.994 & 990 & 10.7 \\
\hline 488.7 & 8.046 & & \\
\hline
\end{tabular}


Westinghouse Savannah River Company

WSRC-TR-2002-00302

Savannah River Technology Center

Page 64 of 64

GFPS-SRAT-165-1

13.5 wt. $\%$ TS

Equivalent sample to 164 in time and place, but never decanted

ThermoHaake RheoWin 3/14/02 / 8:35 AM

Company: SRS Operator: dck

Date: 14.03.2002 Time: 8:19:10 AM Version: RheoWin Pro 291

Substance: 165 Sample no: 1

\begin{tabular}{|c|c|c|c|}
\hline $\mathrm{D}[1 / \mathrm{s}]$ & Tau [Pa] & $\underline{D}[1 / \mathrm{s}]$ & Tau [Pa] \\
\hline 0.0007168 & 0 & 499.7 & 3.534 \\
\hline 0 & 0.004212 & 509 & 3.579 \\
\hline 0.001434 & 0 & 519.1 & 3.601 \\
\hline 9.568 & 1.309 & 529.2 & 3.632 \\
\hline 19.49 & 1.366 & 539.3 & 3.674 \\
\hline 29.3 & 1.447 & 548.8 & 3.691 \\
\hline 39.45 & 1.545 & 559.2 & 3.734 \\
\hline 49.39 & 1.618 & 569.1 & 3.77 \\
\hline 59.19 & 1.685 & 579.2 & 3.81 \\
\hline 69.33 & 1.755 & 589.3 & 3.816 \\
\hline 79.68 & 1.806 & 599 & 3.851 \\
\hline 89.24 & 1.862 & 609.4 & 3.899 \\
\hline 99.55 & 1.921 & 619.3 & 3.923 \\
\hline 109 & 1.976 & 629.2 & 3.96 \\
\hline 119.7 & 2.045 & 639.2 & 4.005 \\
\hline 129.1 & 2.085 & 649 & 4.033 \\
\hline 139 & 2.131 & 659 & 4.064 \\
\hline 149.4 & 2.189 & 669.2 & 4.085 \\
\hline 159.1 & 2.244 & 679.4 & 4.113 \\
\hline 169.3 & 2.272 & 689.2 & 4.155 \\
\hline 180.4 & 2.327 & 699.2 & 4.185 \\
\hline 189.1 & 2.365 & 709.3 & 4.227 \\
\hline 199.3 & 2.418 & 719.2 & 4.259 \\
\hline 209.5 & 2.463 & 729.1 & 4.29 \\
\hline 219.1 & 2.5 & 739.4 & 4.308 \\
\hline 229.6 & 2.54 & 749 & 4.361 \\
\hline 239 & 2.601 & 759.2 & 4.378 \\
\hline 249.1 & 2.631 & 769.5 & 4.421 \\
\hline 259.5 & 2.671 & 779 & 4.444 \\
\hline 269.2 & 2.703 & 789.4 & 4.496 \\
\hline 279.4 & 2.754 & 799.3 & 4.527 \\
\hline 288.9 & 2.788 & 809.1 & 4.552 \\
\hline 299.4 & 2.84 & 819.5 & 4.585 \\
\hline 308.7 & 2.866 & 829.3 & 4.616 \\
\hline 319.3 & 2.91 & 839.1 & 4.656 \\
\hline 329.8 & 2.946 & 849.4 & 4.689 \\
\hline 339.5 & 2.982 & 859.5 & 4.731 \\
\hline 349.1 & 3.031 & 869.4 & 4.763 \\
\hline 359.4 & 3.054 & 879.1 & 4.778 \\
\hline 369.4 & 3.106 & 889.2 & 4.851 \\
\hline 379.5 & 3.138 & 899.1 & 4.917 \\
\hline 389.3 & 3.172 & 909.2 & 5.051 \\
\hline 399.2 & 3.205 & 919.3 & 5.181 \\
\hline 409.1 & 3.246 & 929.3 & 5.302 \\
\hline 419.2 & 3.266 & 939.5 & 5.426 \\
\hline 429 & 3.309 & 949.2 & 5.518 \\
\hline
\end{tabular}


Westinghouse Savannah River Company

WSRC-TR-2002-00302

Savannah River Technology Center

Page 65 of 64

\begin{tabular}{|c|c|c|c|}
\hline 439.3 & 3.335 & 959.4 & 5.65 \\
\hline 449.2 & 3.375 & 969.1 & 5.742 \\
\hline 459.3 & 3.42 & 979 & 5.851 \\
\hline 469.1 & 3.438 & 989.1 & 6.011 \\
\hline 479.2 & 3.486 & 990 & 5.966 \\
\hline 489.4 & 3.502 & & \\
\hline
\end{tabular}


Westinghouse Savannah River Company

WSRC-TR-2002-00302

Savannah River Technology Center

Page 66 of 64

GFPS-SRAT-165-2

decanted since GFPS-SRAT-165-1 to 16.8 wt. \% TS

ThermoHaake RheoWin 3/21/02 / 1:15 PM

Company: SRS Operator: dck

Date: 21.03.2002 Time: 12:59:02 PM Version: RheoWin Pro 291

Substance: 165 Sample no: 2

\begin{tabular}{|c|c|c|c|}
\hline$\underline{D}[1 / s]$ & Tau [Pa] & $\underline{D}[1 / s]$ & $\underline{\text { Tau }[\mathrm{Pa}]}$ \\
\hline 0.0004301 & 0 & 508.7 & 7.889 \\
\hline 0.00003584 & 0 & 519 & 7.944 \\
\hline 0.0009319 & 0 & 529 & 7.996 \\
\hline 8.68 & 3.88 & 538.8 & 8.055 \\
\hline 18.92 & 4.12 & 549 & 8.106 \\
\hline 29.02 & 4.294 & 559 & 8.163 \\
\hline 38.8 & 4.461 & 569.3 & 8.215 \\
\hline 49.09 & 4.6 & 578.8 & 8.271 \\
\hline 59.06 & 4.739 & 589 & 8.336 \\
\hline 68.69 & 4.842 & 598.7 & 8.378 \\
\hline 79.01 & 4.973 & 608.8 & 8.432 \\
\hline 88.8 & 5.071 & 619.1 & 8.483 \\
\hline 98.74 & 5.178 & 629.1 & 8.533 \\
\hline 108.7 & 5.279 & 638.9 & 8.588 \\
\hline 118.7 & 5.378 & 649 & 8.65 \\
\hline 128.9 & 5.449 & 658.8 & 8.685 \\
\hline 138.7 & 5.54 & 668.9 & 8.753 \\
\hline 149 & 5.624 & 678.9 & 8.795 \\
\hline 159.2 & 5.721 & 689 & 8.847 \\
\hline 169.1 & 5.799 & 698.9 & 8.885 \\
\hline 178.9 & 5.885 & 708.7 & 8.945 \\
\hline 189 & 5.951 & 718.7 & 8.983 \\
\hline 199.3 & 6.019 & 729 & 9.043 \\
\hline 209.2 & 6.092 & 739.1 & 9.096 \\
\hline 219.1 & 6.164 & 748.8 & 9.143 \\
\hline 228.7 & 6.231 & 758.9 & 9.192 \\
\hline 238.8 & 6.304 & 768.7 & 9.246 \\
\hline 249.2 & 6.382 & 778.9 & 9.285 \\
\hline 259 & 6.449 & 789.1 & 9.333 \\
\hline 268.8 & 6.513 & 799.1 & 9.382 \\
\hline 278.8 & 6.581 & 808.7 & 9.427 \\
\hline 288.8 & 6.643 & 818.9 & 9.475 \\
\hline 299.1 & 6.692 & 828.8 & 9.528 \\
\hline 309.1 & 6.756 & 839 & 9.582 \\
\hline 319.2 & 6.832 & 849.1 & 9.621 \\
\hline 329 & 6.894 & 859.2 & 9.671 \\
\hline 338.7 & 6.94 & 868.9 & 9.708 \\
\hline 349.1 & 7.002 & 879.3 & 9.778 \\
\hline 358.9 & 7.067 & 888.9 & 9.82 \\
\hline 368.7 & 7.125 & 899 & 9.866 \\
\hline 379.3 & 7.185 & 908.9 & 9.912 \\
\hline 389 & 7.234 & 918.9 & 9.981 \\
\hline 398.9 & 7.298 & 928.8 & 10.02 \\
\hline 408.9 & 7.354 & 938.8 & 10.07 \\
\hline 418.9 & 7.412 & 948.9 & 10.1 \\
\hline 429 & 7.466 & 958.8 & 10.15 \\
\hline
\end{tabular}


Westinghouse Savannah River Company

WSRC-TR-2002-00302

Savannah River Technology Center

Page 67 of 64

\begin{tabular}{|c|c|c|c|}
\hline 438.8 & 7.52 & 969.1 & 10.2 \\
\hline 448.8 & 7.567 & 979 & 10.26 \\
\hline 459 & 7.611 & 988.9 & 10.35 \\
\hline 468.8 & 7.661 & 990 & 10.3 \\
\hline 479 & 7.734 & & \\
\hline 489.1 & 7.79 & & \\
\hline 498.7 & 7.823 & & \\
\hline
\end{tabular}


Westinghouse Savannah River Company

WSRC-TR-2002-00302

Savannah River Technology Center

Page 68 of 64

GFPS-SRAT-164-3

Decanted more since runs $1 \& 2, \sim 18.54$ wt. $\%$ TS

ThermoHaake RheoWin 3/21/02 / 12:52 PM

Company: SRS Operator: dck

Date: 21.03.2002 Time: 12:37:35 PM Version: RheoWin Pro 291

Substance: 164 Sample no: 3

\begin{tabular}{|c|c|c|c|}
\hline$\underline{\mathrm{D}[1 / \mathrm{s}]}$ & $\underline{\text { Tau }[\mathrm{Pa}]}$ & $\underline{D}[1 / \mathrm{s}]$ & $\underline{\text { Tau }[\mathrm{Pa}]}$ \\
\hline 0 & 0.000002371 & 509.7 & 11.71 \\
\hline 0 & 0 & 519.5 & 11.77 \\
\hline 0.0002509 & 0 & 529.7 & 11.85 \\
\hline 9.337 & 5.951 & 540.6 & 11.93 \\
\hline 19.57 & 6.509 & 549.9 & 12 \\
\hline 29.19 & 6.9 & 560 & 12.09 \\
\hline 40.37 & 7.106 & 570 & 12.17 \\
\hline 51 & 7.165 & 579.8 & 12.24 \\
\hline 59.55 & 7.434 & 589.9 & 12.31 \\
\hline 69.71 & 7.601 & 599.5 & 12.38 \\
\hline 79.76 & 7.817 & 609.5 & 12.45 \\
\hline 89.84 & 7.912 & 619.8 & 12.5 \\
\hline 99.94 & 8.039 & 629.7 & 12.57 \\
\hline 109.8 & 8.169 & 640.1 & 12.66 \\
\hline 119.8 & 8.278 & 649.9 & 12.72 \\
\hline 129.6 & 8.4 & 659.8 & 12.79 \\
\hline 139.8 & 8.513 & 669.8 & 12.86 \\
\hline 149.9 & 8.625 & 679.5 & 12.92 \\
\hline 159.9 & 8.739 & 689.7 & 12.99 \\
\hline 169.8 & 8.851 & 699.5 & 13.06 \\
\hline 180.1 & 8.937 & 709.5 & 13.11 \\
\hline 189.8 & 9.051 & 719.5 & 13.18 \\
\hline 200.1 & 9.136 & 729.5 & 13.23 \\
\hline 209.5 & 9.229 & 739.8 & 13.31 \\
\hline 219.6 & 9.317 & 749.6 & 13.38 \\
\hline 229.8 & 9.418 & 759.7 & 13.44 \\
\hline 239.7 & 9.508 & 769.5 & 13.5 \\
\hline 249.6 & 9.597 & 779.7 & 13.56 \\
\hline 259.5 & 9.68 & 789.7 & 13.62 \\
\hline 269.8 & 9.776 & 799.8 & 13.68 \\
\hline 279.8 & 9.854 & 809.8 & 13.75 \\
\hline 290.1 & 9.944 & 819.6 & 13.81 \\
\hline 299.5 & 10.03 & 829.8 & 13.89 \\
\hline 309.5 & 10.1 & 839.6 & 13.94 \\
\hline 319.7 & 10.19 & 849.8 & 14.01 \\
\hline 329.8 & 10.28 & 859.8 & 14.06 \\
\hline 339.5 & 10.35 & 869.7 & 14.12 \\
\hline 349.8 & 10.44 & 879.6 & 14.18 \\
\hline 359.6 & 10.52 & 889.8 & 14.25 \\
\hline 369.5 & 10.59 & 900.3 & 14.3 \\
\hline 379.5 & 10.67 & 909.8 & 14.38 \\
\hline 389.8 & 10.74 & 919.5 & 14.43 \\
\hline 399.7 & 10.82 & 929.6 & 14.51 \\
\hline 409.4 & 10.89 & 939.6 & 14.56 \\
\hline 419.7 & 10.99 & 949.5 & 14.63 \\
\hline 429.5 & 11.06 & 959.9 & 14.68 \\
\hline
\end{tabular}


Westinghouse Savannah River Company

WSRC-TR-2002-00302

Savannah River Technology Center

Page 69 of 64

\begin{tabular}{|c|c|c|c|}
\hline 439.4 & 11.14 & 970.1 & 14.75 \\
\hline 449.9 & 11.21 & 979.7 & 14.8 \\
\hline 459.6 & 11.3 & 988.9 & 14.92 \\
\hline 469.8 & 11.38 & 990 & \\
\hline 479.9 & 11.47 & & \\
\hline 489.9 & 11.54 & & \\
\hline 499.4 & 11.61 & & \\
\hline
\end{tabular}


Westinghouse Savannah River Company

WSRC-TR-2002-00302

Savannah River Technology Center

Page 70 of 64

GFPS-SRAT-174-2

Z41 Concentric cylinder

17.67 wt. \% TS, 5.24 wt. \% SS

ThermoHaake RheoWin 3/18/02 / 3:09 PM

(no sign of bubbles at end of run)

Company: SRS Operator: dck

Date: 18.03.2002 Time: 14:53:23 PM Version: RheoWin Pro 291

Substance: GFPS-SRAT-174 Sample no: 2

\begin{tabular}{|c|c|c|c|}
\hline$\underline{\mathrm{D}[1 / \mathrm{s}]}$ & $\underline{\text { Tau }[\mathbf{P a}]}$ & $\underline{D}[\mathbf{1} / \mathbf{s}]$ & $\underline{\text { Tau }[\mathrm{Pa}]}$ \\
\hline 0.001075 & 0 & 499.3 & 8.018 \\
\hline 0 & 0.007654 & 509.2 & 8.07 \\
\hline 0 & 0 & 518.8 & 8.154 \\
\hline 8.847 & 4.314 & 528.9 & 8.195 \\
\hline 19.1 & 4.515 & 538.7 & 8.265 \\
\hline 28.88 & 4.606 & 549.1 & 8.312 \\
\hline 38.8 & 4.737 & 558.9 & 8.357 \\
\hline 49.34 & 4.875 & 569.2 & 8.441 \\
\hline 58.73 & 4.972 & 579 & 8.492 \\
\hline 68.97 & 5.091 & 588.7 & 8.528 \\
\hline 79.14 & 5.208 & 598.9 & 8.593 \\
\hline 88.82 & 5.303 & 609.3 & 8.641 \\
\hline 98.94 & 5.404 & 619 & 8.686 \\
\hline 109 & 5.489 & 629.2 & 8.751 \\
\hline 118.9 & 5.573 & 639 & 8.794 \\
\hline 128.8 & 5.667 & 649.1 & 8.862 \\
\hline 139.3 & 5.755 & 659 & 8.915 \\
\hline 148.7 & 5.821 & 668.9 & 8.966 \\
\hline 159.1 & 5.912 & 679.1 & 9.012 \\
\hline 168.9 & 5.995 & 689.4 & 9.071 \\
\hline 178.9 & 6.063 & 699.4 & 9.124 \\
\hline 189.4 & 6.129 & 709.2 & 9.175 \\
\hline 198.8 & 6.204 & 718.8 & 9.216 \\
\hline 209.5 & 6.284 & 728.9 & 9.273 \\
\hline 219.4 & 6.354 & 738.6 & 9.317 \\
\hline 229.3 & 6.421 & 748.8 & 9.388 \\
\hline 239 & 6.48 & 758.7 & 9.438 \\
\hline 249.3 & 6.545 & 768.9 & 9.485 \\
\hline 259.8 & 6.627 & 778.8 & 9.535 \\
\hline 268.7 & 6.688 & 789.1 & 9.58 \\
\hline 279.3 & 6.741 & 799.3 & 9.639 \\
\hline 289.1 & 6.809 & 808.9 & 9.676 \\
\hline 298.7 & 6.866 & 819 & 9.74 \\
\hline 309 & 6.936 & 828.8 & 9.772 \\
\hline 318.7 & 6.982 & 839.5 & 9.828 \\
\hline 329.3 & 7.054 & 848.9 & 9.894 \\
\hline 339 & 7.122 & 859 & 9.931 \\
\hline 348.8 & 7.184 & 869 & 9.987 \\
\hline 359 & 7.237 & 879.1 & 10.05 \\
\hline 369 & 7.285 & 889.1 & 10.11 \\
\hline 379.3 & 7.356 & 899.6 & 10.16 \\
\hline 389 & 7.401 & 908.8 & 10.19 \\
\hline 398.7 & 7.454 & 919.5 & 10.24 \\
\hline 409 & 7.525 & 928.9 & 10.29 \\
\hline 419 & 7.582 & 938.9 & 10.34 \\
\hline 429.1 & 7.63 & 948.8 & 10.39 \\
\hline
\end{tabular}


Westinghouse Savannah River Company

WSRC-TR-2002-00302

Savannah River Technology Center

Page 71 of 64

\begin{tabular}{|c|c|c|c|}
\hline 438.7 & 7.69 & 959.1 & 10.45 \\
\hline 448.9 & 7.74 & 969.3 & 10.5 \\
\hline 458.7 & 7.822 & 979.2 & 10.58 \\
\hline 469.2 & 7.858 & 988.9 & 10.64 \\
\hline 479.2 & 7.914 & 990 & 10.6 \\
\hline 488.6 & 7.96 & & \\
\hline
\end{tabular}


Westinghouse Savannah River Company

WSRC-TR-2002-00302

Savannah River Technology Center

Page 72 of 64

GFPS-SRAT-174-3

$\sim 20.2$ wt. $\%$ TS, $\sim 6.1$ wt. $\%$ SS

ThermoHaake RheoWin 3/26/02 / 9:27 AM

Company: SRS Operator: dck

Date: 26.03.2002 Time: 9:12:36 AM Version: RheoWin Pro 291

Substance: 174 Sample no: 3

\begin{tabular}{|c|c|c|c|}
\hline$\underline{D}[1 / \mathrm{s}]$ & Tau $[\mathrm{Pa}]$ & $\underline{D}[1 / \mathrm{s}]$ & Tau [Pa] \\
\hline 0 & 0 & 510.4 & 19.55 \\
\hline 0 & 0 & 521 & 19.65 \\
\hline 0 & 0 & 530.6 & 19.76 \\
\hline 20.68 & 10.93 & 540.6 & 19.86 \\
\hline 30.47 & 11.41 & 550.5 & 19.98 \\
\hline 41.23 & 11.96 & 560.8 & 20.11 \\
\hline 50.56 & 12.68 & 570.7 & 20.21 \\
\hline 61.5 & 12.51 & 580.7 & 20.3 \\
\hline 70.7 & 12.86 & 590.8 & 20.4 \\
\hline 80.98 & 12.99 & 600.5 & 20.49 \\
\hline 90.67 & 13.24 & 611 & 20.56 \\
\hline 101.2 & 13.5 & 620.6 & 20.64 \\
\hline 110.4 & 14.29 & 630.7 & 20.73 \\
\hline 120.7 & 14.01 & 640.6 & 20.8 \\
\hline 130.8 & 14.23 & 650.7 & 20.87 \\
\hline 140.8 & 14.42 & 660.7 & 20.95 \\
\hline 150.7 & 14.62 & 670.9 & 21.02 \\
\hline 160.8 & 14.76 & 680.6 & 21.1 \\
\hline 171.2 & 14.97 & 691 & 21.16 \\
\hline 180.8 & 15.08 & 700.9 & 21.21 \\
\hline 190.6 & 15.22 & 710.8 & 21.28 \\
\hline 200.6 & 15.41 & 721 & 21.34 \\
\hline 211.1 & 15.59 & 730.8 & 21.38 \\
\hline 220.7 & 15.75 & 740.6 & 21.41 \\
\hline 230.7 & 15.91 & 750.5 & 21.44 \\
\hline 240.8 & 16.08 & 761.2 & 21.46 \\
\hline 250.7 & 16.23 & 770.6 & 21.48 \\
\hline 260.5 & 16.36 & 781.1 & 21.5 \\
\hline 270.6 & 16.52 & 791.1 & 21.51 \\
\hline 280.9 & 16.65 & 800.5 & 21.51 \\
\hline 290.9 & 16.79 & 810.9 & 21.54 \\
\hline 300.5 & 16.92 & 820.8 & 21.56 \\
\hline 310.4 & 17.05 & 830.5 & 21.57 \\
\hline 321.1 & 17.21 & 841.2 & 21.58 \\
\hline 330.5 & 17.35 & 851.1 & 21.58 \\
\hline 340.8 & 17.49 & 860.9 & 21.6 \\
\hline 350.8 & 17.61 & 870.9 & 21.63 \\
\hline 361.1 & 17.74 & 881 & 21.66 \\
\hline 370.6 & 17.86 & 890.7 & 21.66 \\
\hline 381 & 18 & 900.8 & 21.7 \\
\hline 390.7 & 18.12 & 910.7 & 21.73 \\
\hline 400.8 & 18.25 & 920.7 & 21.77 \\
\hline 410.6 & 18.36 & 930.7 & 21.79 \\
\hline 420.8 & 18.49 & 940.7 & 21.82 \\
\hline 430.7 & 18.61 & 950.9 & 21.86 \\
\hline 440.8 & 18.72 & 960.8 & 21.91 \\
\hline
\end{tabular}


Westinghouse Savannah River Company

WSRC-TR-2002-00302

Savannah River Technology Center

Page 73 of 64

\begin{tabular}{|c|c|c|c|}
\hline 450.9 & 18.83 & 970.8 & 21.96 \\
\hline 461 & 18.96 & 980.6 & 21.99 \\
\hline 471 & 19.08 & 990 & 22.05 \\
\hline 480.6 & 19.19 & & \\
\hline 490.9 & 19.32 & & \\
\hline 500.7 & 19.43 & & \\
\hline & & & \\
\hline & & & \\
\hline
\end{tabular}


Westinghouse Savannah River Company

WSRC-TR-2002-00302

Savannah River Technology Center

Page 74 of 64

GFPS-SRAT-196-1

18.2 wt. \% TS, 5.2 wt. \% SS

ThermoHaake RheoWin 3/26/02 / 10:13 AM

Company: SRS Operator: dck

Date: 26.03.2002 Time: 9:53:08 AM Version: RheoWin Pro 291

Substance: 196 Sample no: 1

\begin{tabular}{|c|c|c|c|}
\hline $\mathrm{D}[1 / \mathrm{s}]$ & Tau $[\mathrm{Pa}]$ & D [1/s] & Tau [Pa] \\
\hline 0 & 0 & 499.1 & 8.708 \\
\hline 0 & 0.00001793 & 509.5 & 8.677 \\
\hline 0.0007527 & 0 & 519 & 8.678 \\
\hline 8.914 & 4.319 & 528.9 & 8.678 \\
\hline 18.94 & 4.535 & 539.2 & 8.701 \\
\hline 28.95 & 4.74 & 549.1 & 8.735 \\
\hline 39.3 & 4.93 & 559 & 8.761 \\
\hline 49.13 & 5.097 & 569.4 & 8.806 \\
\hline 58.74 & 5.235 & 579.3 & 8.853 \\
\hline 69.18 & 5.392 & 589.2 & 8.91 \\
\hline 79.04 & 5.549 & 598.9 & 8.96 \\
\hline 88.98 & 5.648 & 609.3 & 9.004 \\
\hline 99.23 & 5.753 & 619 & 9.047 \\
\hline 109.1 & 5.87 & 629.1 & 9.11 \\
\hline 119.3 & 5.987 & 639.1 & 9.157 \\
\hline 129.3 & 6.113 & 649.1 & 9.209 \\
\hline 139.2 & 6.235 & 659.7 & 9.249 \\
\hline 149 & 6.338 & 669.1 & 9.308 \\
\hline 159.2 & 6.462 & 679.2 & 9.339 \\
\hline 169.6 & 6.577 & 689.3 & 9.393 \\
\hline 179 & 6.695 & 699.3 & 9.446 \\
\hline 189.4 & 6.805 & 708.8 & 9.491 \\
\hline 199.3 & 6.921 & 719.4 & 9.553 \\
\hline 209.3 & 7.033 & 728.9 & 9.587 \\
\hline 219.1 & 7.139 & 739 & 9.65 \\
\hline 228.9 & 7.23 & 749.2 & 9.705 \\
\hline 239.4 & 7.343 & 758.9 & 9.753 \\
\hline 249.4 & 7.435 & 769.4 & 9.792 \\
\hline 259 & 7.536 & 779 & 9.83 \\
\hline 268.9 & 7.636 & 789.2 & 9.89 \\
\hline 279.3 & 7.725 & 798.8 & 9.929 \\
\hline 289.3 & 7.815 & 809.1 & 9.993 \\
\hline 299.1 & 7.9 & 818.9 & 10.03 \\
\hline 309 & 7.991 & 829.3 & 10.06 \\
\hline 319.3 & 8.078 & 839 & 10.13 \\
\hline 329.1 & 8.173 & 849.1 & 10.15 \\
\hline 339.1 & 8.246 & 858.9 & 10.21 \\
\hline 349.6 & 8.322 & 869.2 & 10.25 \\
\hline 359 & 8.391 & 878.8 & 10.28 \\
\hline 369.2 & 8.458 & 889.1 & 10.34 \\
\hline 379.2 & 8.526 & 898.9 & 10.38 \\
\hline 389.5 & 8.599 & 909 & 10.43 \\
\hline 398.9 & 8.645 & 919.1 & 10.49 \\
\hline 409.1 & 8.721 & 929 & 10.52 \\
\hline 419.3 & 8.761 & 938.8 & 10.56 \\
\hline 428.9 & 8.808 & 949.1 & 10.6 \\
\hline
\end{tabular}

\section{(Run 2 SRAT Product)}


Westinghouse Savannah River Company

WSRC-TR-2002-00302

Savannah River Technology Center

Page 75 of 64

\begin{tabular}{|c|c|c|c|}
\hline 439 & 8.812 & 959.1 & 10.65 \\
\hline 448.9 & 8.815 & 968.9 & 10.69 \\
\hline 458.8 & 8.798 & 978.9 & 10.75 \\
\hline 469.1 & 8.77 & 989.3 & 10.83 \\
\hline 479.2 & 8.756 & 989.8 & 10.8 \\
\hline 489.2 & 8.752 & 990 & 10.79 \\
\hline
\end{tabular}

